Agro-Science Journal of Tropical Agriculture, Food, Environment and Extension Volume 8 Number 2 Mav 2009 pp $74-83$

ISSN 1119-7455

\title{
AGRONOMIC ASSESSMENT OF SOME SWEET POTATO VARIETIES FOR INTERCROPPING WITH PIGEONPEA IN SOUTHERN GUINEA SAVANNA OF NIGERIA
}

\author{
Egbe, O.M ${ }^{1}$. and Idoko, J.A ${ }^{2}$. \\ ${ }^{1}$ Department of Plant Breeding and Seed Science, University of Agriculture, Makurdi, Benue \\ State, Nigeria. \\ ${ }^{2}$ Department of Agricultural Education, University of Agriculture, Makurdi, Benue State, \\ Nigeria.
}

\begin{abstract}
Field experiments were conducted at the National Root Crops Research Institute sub-station, Otobi, in 2006 and 2007 to assess the suitability of improved sweet potato varieties for intercropping with pigeonpea and also to determine the planting pattern and the productivity of the intercropping system. Intercropping decreased total fresh root and saleable root yields of sweet potato when mixed or row-intercropped with pigeonpea. All intercropping combinations of sweet potato varieties and pigeonpea had land equivalent ratio above 1.0, except intercropping with WA Gabolige, signifying high intercrop advantages. TIS $87 / 0087$ produced the highest total fresh root and saleable root yields in both cropping systems, irrespective of the planting pattern used. TIS 2532.O.P.1.13 and TIS 86/00356 sweet potato varieties had comparable yields with TIS 87/0087 in both cropping systems. Pigeonpea was the more competitive component of the intercrop. Farmers showed willingness to adopt the sweet potato + pigeonpea intercropping.
\end{abstract}

Keywords: Intercropping, sweet potato, pigeonpea, Guinea Savanna, Nigeria.

\section{INTRODUCTION}

Sweet potato (Ipomea batatas $\mathrm{L}$. Lam) is a major food and industrial root crop in Nigeria with an estimated annual production of 2.52 million tons (FAO, 2004), and the mean yield on farmers' fields (3-7 t/ha) is considered low (Udealor et al., 2006). Sweet potato has a long history as a crop to stave off famine-especially as a cheap source of calories (Adam, 2005). Pigeonpea (Cajanus cajan (L.) Millsp.) is a multipurpose leguminous crop that can provide food, fuelwood and fodder for small-scale farmers in subsistence agriculture (Egbe and Kalu, 2006). Intercropping sweet potato with pigeonpea would ensure the supply of dietary carbohydrate, protein, fats, vitamins and minerals (calcium, magnesium, copper, iron, and zinc) for the rural household. Intercropping both sweet potato with pigeonpea will not only ensure better environmental resource utilization, but will also provide better yield stability, reduce pests and diseases and diversify rural income (Egbe, 2005; Njoku et al., 2007). Although presently unpopular, growing sweet potato with pigeonpea in mixtures or intercropping has enormous potentials in Southern Guinea Savanna agro-ecological zone of Nigeria, where poverty level is high, income generation opportunities are few and soil fertility status is low (Egbe, 2005; Egbe and Kalu, 2006).

The sweet potato variety commonly cultivated by farmers in the Southern Guinea Savanna Zone of Nigeria often results in low yields of 3-9.0 t ha ${ }^{-1}$ (BNARDA, 2007) and when intercropped with pigeonpea, the planting pattern is highly variable from one farm to the other. Though yield advantages occur in sweet potato intercropped with such other crops as maize and okra (Udealor et al., 2006; Njoku et al., 2007) and in pigeonpea intercropping with maize and sorghum (Egbe and Adeyemo, 2006; Egbe, 2005), documented information on yield advantages derivable from sweet potato + pigeonpea intercropping are lacking. The work reported here sought to determine the suitability of sweet potato varieties for intercropping with pigeonpea and to assess the productivity of the intercropping systems with the aim of enhancing food security in the region. The work also aimed at popularizing new sweet potato varieties suitable for intercropping in the Southern Guinea Savanna of Nigeria 


\section{MATERIALS AND METHODS}

The study was conducted at the National Root Crops Research Institute SubStation, Otobi $\left(07^{0} 10^{\prime} \mathrm{N}, 08^{0} 39^{\prime} \mathrm{E}\right.$, elevation $105.1 \mathrm{~m})$ in Benue State, located in the Southern Guinea Savanna of Nigeria (Kowal and Knabe, 1972). The texture of the top soil $(0-30 \mathrm{~cm})$ of the experimental site was sandy loam. The soil at the experimental site was classified as Typic Paleustalf (USDA). Eight core samples of soil were collected from different parts of the experimental field and bulked into a composite sample and used for the determination of the chemical and physical properties of the soil before planting. The level of total nitrogen $(\mathrm{N})$ was $0.52 \%$, phosphorus and potassium averaged 68.20 and $43.50 \mathrm{mg} \mathrm{kg}^{-1}$ soil, respectively. The rainfall amounts at the site were $1250.8 \mathrm{~mm}$ and $1301.1 \mathrm{~mm}$ in 2006 and 2007, respectively. The rains fell between the months of July and November of each year. The experimental field was ploughed, harrowed and ridged before planting in each year of the experimentation. The experiment was a $2 \times 6 \times 2$ factorial set out in split-split plot in a randomized complete block design with three replications. The main-plot treatments were two cropping systems (i) sole cropping (sweet potato, pigeonpea) and (ii) intercropping (sweet potato + pigeonpea). The sub-plot treatments comprised of five improved sweet potato varieties obtained from the National Root Crops Research Institute, Umudike, and a local check (TIS 87/0087, CIP Tanzania, WA Gabolige, TIS 2532.OP.I.13, TIS 86/00356 and Ogege-local check). The sub-sub-plot treatments were made up of two planting patterns of pigeonpea + sweet potato intercropping [mixture (top) and rowintercropping (side). The gross plot comprised of 5 ridges each of $4 \mathrm{~m}$ long $\left(20 \mathrm{~m}^{2}\right)$, while the net plot had 3 ridges each of $3 \mathrm{~m}$ long $\left(9 \mathrm{~m}^{2}\right)$. Plantings were done on the $20^{\text {th }}$ and $24^{\text {th }}$ July in 2006 and 2007, respectively. Sweet potato vine cuttings measuring $20 \mathrm{~cm}$ with four nodes were planted at the crest of ridges at a spacing of $1 \mathrm{~m} \times 0.3 \mathrm{~m}$ (33,000 plants per hectare). Pigeonpea seeds obtained from the local market in Otobi were simultaneously planted at $1 \mathrm{~m} \mathrm{x} 0.3 \mathrm{~m}$ with two seeds per hole and at two different positions: (i) planting by side of ridge (row-intercropping) and (ii) at the top in between the sweet potato (mixture). The pigeonpea was thinned to one plant per stand at 10 days after planting to give a plant population of 33,000 plants per hectare (ha). Weeding was done at three weeks after planting (WAP). No fertilizer was applied. In addition to the on-station experiment, in 2007, ten farmers were randomly selected from five villages around Otobi for on-farm evaluation of TIS $87 / 0087$ mixed or row-intercropped with pigeonpea. TIS $87 / 0087$ was picked because it gave the highest yield in both cropping systems in 2006. The on-farm experiment consisted of four treatments, viz: (i) TIS 87/0087 intercropped with pigeonpea planted at ridge crest (ii)TIS 87/0087 intercropped with pigeonpea planted by the side of the ridge (iii) Sole TIS 87/0087 (iv) Sole pigeonpea.The spacing adopted for both sweet potato and pigeonpea were as in the onstation experiments. The gross plot size was $10 \mathrm{mx} 5 \mathrm{~m}\left(50 \mathrm{~m}^{2}\right)$ and the net plot measured 6 $\mathrm{m} \times 3 \mathrm{~m}\left(18 \mathrm{~m}^{2}\right)$. Harvesting of sweet potato was done as reported by Njoku et al. (2007). At harvest the following parameters were measured from the net plot:

Sweet potato component: Total fresh root yield consisted of the weight of all tuberous roots and saleable root yield (weight of tuberous roots $\geq 200 \mathrm{~g}$, devoid of insect and disease attack as well as harvest injuries).

(ii) Pigeonpea component: Number of pods per plant (average of five plants per plot) and total grain yield.

After harvest, the ten farmers involved in the on-farm experimentation were brought together and asked which of the experimental treatments they preferred to adopt. Questionnaires were also administered on the farmers to record their choices of the preferred experimental treatments.

All data collected were analysed using GENSTAT 4.23 (Copyright 2003, Lowes Agricultural Trust Rothamsted Experimental Station) following Standard analysis of variance procedures (Gomez and Gomez, 1984). Whenever difference between treatment means were significant, means were separated by F-LSD at $\mathrm{P}=0.05$ (Obi, 1990). The land equivalent ratio (LER) (Anders et al., 1996) and competitive ratio (CR) (Putnam et al., 1984), calculated from total fresh root yield of sweet potato and grain yield of pigeonpea, were used to determine the productivity of the intercropping systems. The LER, an accurate assessment of the biological efficiency of the intercropping situation, was calculated as LER $=(\mathrm{X} a b / \mathrm{X} a a)+(\mathrm{X} b a / \mathrm{X} b b)$ where $\mathrm{X} a a$ and $\mathrm{X} b b$ are yields as sole crops of $a$ and $b$ and $\mathrm{X} a b$ and $\mathrm{X} b a$ are yields as intercrop of $a$ and $b$. Values of LER greater than 1 are considered as advantageous.

Similarly, competitive ratio (CR) which simply represents the ratio of individual 
LERs of the two component crops, but takes into account the proportion of the crops in which there were initially sown, was calculated as

$$
\begin{aligned}
\mathrm{CR} & =\mathrm{L} a / \mathrm{L} b \text { X Z } b a / \mathrm{Z} a b \\
\text { Where } \mathrm{L} a & =\mathrm{LER} \text { of crop } a \\
\mathrm{~L} b & =\text { LER of crop } b \\
\mathrm{Z} b a & =\text { Proportion of crop a in } a b \text { in } \\
\mathrm{Z} a b & =\text { intercrop } \\
& \text { intercrop }
\end{aligned}
$$

CR could be useful in comparing the competitive ability of the different crops, measuring competitive changes in a given situation, identify which plant characters are associated with competitive ability and determining which competitive balance between component crops is most likely to give maximum yield advantages.

\section{RESULTS}

Tables 1-3 present the effects of cropping system $\mathrm{x}$ variety, cropping system $\mathrm{x}$ planting position, variety $\mathrm{x}$ position of planting, respectively and their interactions on the total fresh root yield of sweet potato intercropped with pigeonpea at Otobi. In 2006, intercropping reduced the fresh root yield of sweet potato in all the varieties, except CIP Tanzania, which had a reverse response. However, intercropped sweet potato varieties such as TIS 87/0087, TIS 2532.OP.1.13 and
TIS 86/00356 gave significantly higher fresh root yield than when grown in sole in 2007.The responses of the other varieties (Ogege(local check),WA Gabolige and CIP Tanzania) to intercropping were insignificant in 2007(Table 1).Under intercropping, sweet potato planted on top with pigeonpea gave higher fresh root yields than side planting in 2006(Tables2\&3).

Tables 4,5 and 6 present results of the effects of cropping systems $x$ variety, cropping systems $x$ position of planting and variety $\mathrm{x}$ planting position respectively, and their interactions on the saleable root yield of sweet potato intercropped with pigeonpea in 2006 and 2007 at Otobi.Intercropping consistently reduced the saleable root yield of all sweet potato varieties intercropped with pigeonpea in both years of experimentation(Table 4).Under sole cropping, WA Gabolige gave the least saleable root yield in 2006, while CIP Tanzania did so in 2007.Intercropped sweet potato planted on top with pigeonpea gave significantly higher yields of saleable root than side planting in both years(Table 5).Similarly, TIS 87/0087,TIS 2532.OP.1.13 and TIS $86 / 00356$ produced significantly higher yields of saleable roots when planted on top of the ridge with pigeonpea than when planted by the side(Table 6). The other improved sweet potato varieties(CIP Tanzania and WA Gabolige) and the local check gave insignificant results.

Table 1: Effects of cropping system $x$ variety and their interactions on the total fresh root yield $\left(\mathrm{t} \mathrm{ha} \mathrm{h}^{-1}\right)$ of sweet potato intercropped with pigeonpea in 2006 and 2007 at Otobi

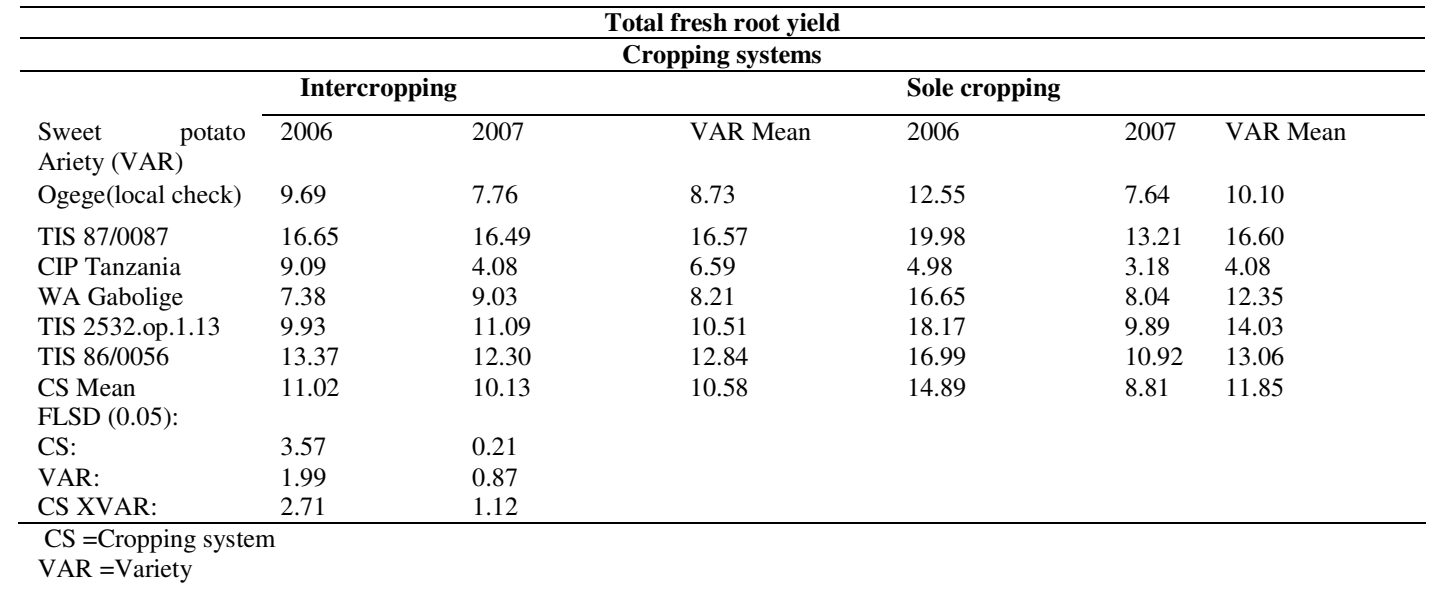


Agronomic Assessment of Some Sweet Potato Varieties

Table 2: Effects of cropping system $x$ planting position and their interactions on the total fresh root yield $\left(\mathrm{t} / \mathrm{ha}^{-1}\right)$ of sweet potato intercropped with pigeonpea 2007 at Otobi.

\begin{tabular}{|c|c|c|c|c|c|c|}
\hline \multicolumn{7}{|c|}{ Total fresh root yield } \\
\hline \multicolumn{7}{|c|}{ Position of planting (POP) } \\
\hline & \multicolumn{3}{|c|}{ Side } & \multicolumn{3}{|c|}{ Top } \\
\hline Cropping system (CS) & 2006 & 2007 & Mean & 2006 & 2007 & Mean \\
\hline Sole cropping & 14.75 & 11.53 & 13.04 & 15.02 & 6.29 & 10.6 \\
\hline Intercropping & 9’79 & 11.54 & 10.67 & $14^{\prime} 60$ & 11.10 & 12.85 \\
\hline Pop Mean & 1220 & $11 ’ 32$ & $11^{\prime} 85$ & $14{ }^{\prime} 81$ & 8.70 & 11.76 \\
\hline FLSD (0.05) & & & & & & \\
\hline CS: & 3.57 & 0.21 & & & & \\
\hline Pop: & 0.21 & 0.61 & & & & \\
\hline CS x Pop: & 3.49 & 0.70 & & & & \\
\hline
\end{tabular}

Table 3:Effects of variety $x$ planting position and their interactions on the total fresh root yield $\left(\mathrm{tha}^{-1}\right)$ of sweet potato intercropped with pigeonpea in 2006 and 2007 at Otobi.

\begin{tabular}{|c|c|c|c|c|c|c|}
\hline \multicolumn{7}{|c|}{ Total fresh root yield(CS) } \\
\hline \multicolumn{7}{|c|}{ Planting position(POP) } \\
\hline & \multicolumn{3}{|c|}{ Side } & \multicolumn{3}{|c|}{ Top } \\
\hline Sweet potato variety(VAR) & 2006 & 2007 & VAR Mean & 2006 & 2007 & VAR Mean \\
\hline Ogege(Local check) & 9.77 & 9.40 & 9.59 & 9.62 & 6.12 & 7.87 \\
\hline TIS $87 / 0087$ & 13.52 & 16.70 & 15.11 & 19.78 & 16.28 & 18.03 \\
\hline CIP Tanzania & 8.24 & 1.72 & 4.98 & 9.95 & 6.45 & 8.20 \\
\hline WA Gabolige & 6.47 & 13.26 & 9.87 & 8.29 & 4.80 & 6.55 \\
\hline TIS 2532.OP.1.13 & 8.85 & 14.66 & 11.76 & 11.01 & 7.51 & Ss 9.26 \\
\hline TIS $86 / 00356$ & 11.93 & 13.50 & 12.72 & 14.60 & 11.10 & 12.85 \\
\hline POP Mean & 9.79 & 11.54 & 10.67 & 12.21 & 8.71 & 10.46 \\
\hline \multicolumn{7}{|l|}{ FLSD $(0.05)$} \\
\hline VAR: & 1.99 & 0.87 & & & & \\
\hline POP: & 0.21 & 0.69 & & & & \\
\hline VAR X POP & 1.24 & 1.44 & & & & \\
\hline
\end{tabular}

Table 4: Effects of cropping system $x$ variety and their interactions on the saleable root yield $\left(\mathrm{t} \mathrm{ha}^{-1}\right)$ of sweet potato intercropped pigeonpea in 2006 and 2007 at Otobi.

\begin{tabular}{|c|c|c|c|c|c|c|}
\hline \multicolumn{7}{|c|}{ Saleable root yield } \\
\hline \multicolumn{7}{|c|}{ Cropping systems } \\
\hline & \multicolumn{3}{|c|}{ Intercropping } & \multicolumn{3}{|c|}{ Sole cropping } \\
\hline Sweet potato variety(VAR) & 2006 & 2007 & VAR Mean & 2006 & 2007 & VAR Mean \\
\hline Ogege(local check) & 8.63 & 4.56 & 6.60 & 11.57 & 7.90 & 9.74 \\
\hline IS $87 / 0087$ & 15.22 & 11.37 & 13.30 & 17.97 & 14.74 & 16.36 \\
\hline CIP Tanzania & 5.50 & 1.56 & 3.53 & 4.57 & 1.49 & 3.03 \\
\hline WA Gabolige & 3.99 & 0.39 & 2.19 & 12.21 & 8.60 & 10.41 \\
\hline TIS 2532.op.1.13 & 11.15 & 7.21 & 9.18 & 17.16 & 13.52 & 15.34 \\
\hline TIS $86 / 00356$ & 12.30 & 8.21 & 10.26 & 16.39 & 13.02 & 14.71 \\
\hline CS Mean & 9.47 & 5.55 & 7.51 & 13.31 & 9.88 & 11.59 \\
\hline FLSD (0.05): & & & & & & \\
\hline CS: & 1.69 & 0.94 & & & & \\
\hline VAR: & 0.82 & 0.75 & & & & \\
\hline CS XVAR: & 1.41 & 1.08 & & & & \\
\hline
\end{tabular}

CS: =Cropping system

$\mathrm{VAR}=$ Variety 
Egbe, O.M. and Idoko, J.A.

Table 5: Effects of cropping system $x$ planting position and their interactions on the saleable root yield $\left(\mathrm{t} / \mathrm{ha}^{-1}\right)$ of sweet potato intercropped with pigeonpea in 2006 and 2007 at Otobi

CS:=Cropping system

\begin{tabular}{|c|c|c|c|c|c|c|}
\hline \multicolumn{7}{|c|}{ Saleable root yield } \\
\hline & \multicolumn{4}{|c|}{ Position of planting(POP) } & & \\
\hline & & Sic & & & \multicolumn{2}{|c|}{ Top } \\
\hline Cropping system(CS) & 2006 & 2007 & CS Mean & 2006 & 2007 & CS Mean \\
\hline Sole cropping & 13.39 & 10.07 & 11.73 & 13.24 & 9.69 & 11.47 \\
\hline Intercropping & 8.49 & 4.67 & 6.58 & 10.43 & 6.43 & 8.43 \\
\hline POP Mean & 10.94 & 7.37 & 9.16 & 11.84 & 8.06 & 9.95 \\
\hline \multicolumn{7}{|l|}{ FLSD $(0.05)$} \\
\hline CS: & 1.69 & 0.94 & & & & \\
\hline POP: & 0.30 & 0.30 & & & & \\
\hline CS XPOP & 1.46 & 0.73 & & & & \\
\hline
\end{tabular}

Table 6: Effects of variety $x$ planting position and their interactions on the saleable root yield $\left(\mathrm{t} \mathrm{ha}^{-1}\right)$ of sweet potato intercropped with pigeonpea in 2006 and 2007 at Otobi

\begin{tabular}{|c|c|c|c|c|c|c|}
\hline \multicolumn{7}{|c|}{ Saleable root yield(CS) } \\
\hline & \multicolumn{3}{|c|}{ Planting position(POP) } & & & \\
\hline & \multicolumn{3}{|c|}{ Side } & \multicolumn{3}{|c|}{ Top } \\
\hline Sweet potato variety(VAR) & 2006 & 2007 & VAR Mean & 2006 & 2007 & VAR Mean \\
\hline Ogege(Local check) & 8.45 & 4.49 & 6.47 & 8.81 & 4.63 & 6.72 \\
\hline TIS $87 / 0087$ & 12.03 & 8.35 & 10.19 & 18.41 & 14.39 & 16.40 \\
\hline CIP Tanzania & 5.09 & 1.10 & 3.10 & 5.91 & 2.01 & 3.96 \\
\hline WA Gabolige & 3.79 & 0.32 & 2.06 & 4.19 & 0.47 & 2.33 \\
\hline TIS 2532.OP.1.13 & 10.13 & 6.15 & 8.17 & 12.12 & 8.26 & 10.19 \\
\hline TIS 86/00356 & 11.45 & 7.61 & 9.53 & 13.16 & 8.81 & 10.99 \\
\hline POP Mean & 8.49 & 4.67 & 6.58 & 10.43 & 6.43 & 8.43 \\
\hline \multicolumn{7}{|l|}{ FLSD $(0.05)$} \\
\hline VAR: & 0.82 & 0.75 & & & & \\
\hline POP: & 0.30 & 0.30 & & & & \\
\hline VAR X POP & 0.95 & 0.89 & & & & \\
\hline
\end{tabular}

In both 2006 and 2007, sweet potato varieties (WA Gabolge,TIS 2532.OP.1.13 and TIS 86/00356)gave significantly higher number of tuberous roots per plant under intercropping than in sole cropping, but not so with the local check(Ogege),TIS $87 / 0087$ and CIP Tanzania, which gave insignificant responses (Table 7). Intercropping consistently reduced the number of tuberous roots per plant irrespective of the planting position adopted in both years(Table 8).WA Gabolige produced significantly higher number of tuberous roots per plant when planted with pigeonpea at the ridge crest than when planted with pigeonpea by the side,while TIS 86/00356 had the opposite response in both years of experimentation(Table 9).The responses of Ogege,TIS 87/0087,CIP Tanzania and TIS 2532.OP.1.13 at both planting positions were inconsistent and mostly insignificant.

In 2006, sole pigeonpea planted on top of the ridge produced significantly higher number of pods than intercropped pigeonpea with TIS 87/0087 planted on top of ridge, which in turn gave higher number of pods than pigeonpea intercropped with TIS 86/00356 and planted by the side and sole pigeonpea planted also by side (Table 10). All the other combinations gave lower number of pods per plant than the sole pigeonpea planted by the side of the ridge. The trend in 2007 was similar to that obtained in 2006 (Table 4). The results further revealed that intercropped pigeonpea gave lower number of pods per plant than sole planted pigeonpea in 2006, unlike in 2007, when there was no significant difference between both cropping systems. Intercropped pigeonpea planted on top with TIS 87/0087, sole pigeonpea planted on top of ridge, intercropped pigeonpea planted by side of TIS 2532.OP.1.13 and pigeonpea planted by the side of $87 / 0087$ gave higher yields of grain than all the other treatments including sole pigeonpea planted by side of the ridge in both 2006 and 2007 (Table 10). Intercropped pigeonpea by side of WA Gabolige gave the least grain yield in both experimental years. The results further showed that there was no significant difference between sole and intercropped pigeonpea in grain yield in 2006, but sole pigeonpea gave a higher grain yield in 2007 than intercropped pigeonpea. 
All intercrop combinations had LER figures above 1.00, except the combination of pigeonpea and WA Gabolige with the pigeonpea by the side in both years (Table 11). The combination of CIP Tanzania planted at both positions gave the highest LER and this was closely followed by the combination of pigeonpea and TIS $87 / 0087$ with the pigeonpea on top of the ridge. The combination of pigeonpea and WA Gabolige with the pigeonpea planted by the side gave the least LER. Table 11 further indicated that pigeonpea consistently had higher competitive ratio (CR) figures than sweet potato varieties in both years.

Results of yield of Sweet potato variety TIS $87 / 0087$ intercropped with pigeonpea on ten farmers' fields in five villages around Otobi in 2007 are presented in Table 6. TIS $87 / 0087$ planted on top with pigeonpea (mixed cropping) out yielded its planting with pigeonpea by its side (rowintercropping). There was no significant difference between the pigeonpea planted on top with sweet potato and by the side of sweet potato. Eighty percent $(80 \%)$ of the farmers who participated in the research were willing to adopt the technology for various reasons; while twenty percent rejected the practice either because the practice was perceived as being strange or that the harvesting of pigeonpea component was tedious.

Table 7: Effects of cropping system $x$ variety and their interactions on the number tuberous roots per plant of sweet potato intercropped with pigeonpea in 2006 and 2007 at Otobi.

\begin{tabular}{|c|c|c|c|c|c|c|}
\hline \multicolumn{7}{|c|}{ Number of tuberous roots per plant } \\
\hline \multicolumn{7}{|c|}{ Cropping systems $(\mathrm{CS})$} \\
\hline & \multicolumn{3}{|c|}{ Intercropping } & \multicolumn{3}{|c|}{ Sole cropping } \\
\hline Sweet potato variety(VAR) & 2006 & 2007 & VAR Mean & 2006 & 2007 & VAR Mean \\
\hline Ogege(local check) & 0.85 & 0.93 & 0.89 & 0.93 & 0.98 & 0.96 \\
\hline TIS $87 / 0087$ & 1.18 & 1.20 & 1.19 & 1.32 & 1.47 & 1.40 \\
\hline CIP Tanzania & 1.36 & 1.41 & 1.39 & 1.40 & 1.41 & 1.41 \\
\hline WA Gabolige & 1.21 & 1.15 & 1.18 & 2.21 & 2.33 & 2.27 \\
\hline TIS 2532.op.1.13 & 0.75 & 0.85 & 0.80 & 1.55 & 1.62 & 1.59 \\
\hline TIS $86 / 00356$ & 1.66 & 1.73 & 1.70 & 3.07 & 3.28 & 3.18 \\
\hline CS Mean & 1.17 & 1.21 & 1.19 & 1.75 & 1.85 & 1.80 \\
\hline FLSD (0.05): & & & & & & \\
\hline CS: & 0.31 & 0.25 & & & & \\
\hline VAR: & 0.17 & 0.16 & & & & \\
\hline CS XVAR: & 0.27 & 0.24 & & & & \\
\hline
\end{tabular}

CS:=Cropping system

VAR:=Variety

Table 8: Effects of cropping system $x$ planting position and their interactions on the number of tuberous roots per plant of sweet potato intercropped with pigeonpea in 2006 and 2007 at Otobi.

\begin{tabular}{|c|c|c|c|c|c|c|}
\hline \multicolumn{7}{|c|}{ Saleable root yield } \\
\hline & \multicolumn{5}{|c|}{ Position of planting(POP) } & \\
\hline & \multicolumn{3}{|c|}{ Side } & \multicolumn{2}{|c|}{ Top } & \\
\hline Cropping system(CS) & 2006 & 2007 & CS Mean & 2006 & 2007 & CS Meaan \\
\hline Sole cropping & 1.74 & 1.80 & 1.77 & 1.75 & 1.89 & 1.82 \\
\hline Intercropping & 1.21 & 1.26 & 1.23 & 1.13 & 1.16 & 1.15 \\
\hline POP Mean & 1.48 & 1.53 & 1.45 & 1.44 & 1.53 & 1.49 \\
\hline FLSD $(0.05)$ & & & & & & \\
\hline CS: & 0.31 & 0.25 & & & & \\
\hline POP: & 0.08 & 0.07 & & & & \\
\hline CS XPOP & & & & & & \\
\hline
\end{tabular}


Table 9: Effects of variety $x$ planting position and their interactions on the number of tuberous roots per plant of sweet potato intercropped with pigeonpea in 2006 and 2007 at Otobi.

\begin{tabular}{|c|c|c|c|c|c|c|}
\hline \multicolumn{7}{|c|}{ Saleable root yield(CS) } \\
\hline \multicolumn{7}{|c|}{ Planting position(POP) } \\
\hline & \multicolumn{3}{|c|}{ Side } & \multicolumn{3}{|c|}{ Top } \\
\hline Sweet potato variety(VAR) & 2006 & 2007 & VAR Mean & 2006 & 2007 & VAR Mean \\
\hline Ogege(Local check) & 0.85 & 0.94 & 0.89 & 0.84 & 0.92 & 0.88 \\
\hline TIS $87 / 0087$ & 1.14 & 1.25 & 1.19 & 1.21 & 1.15 & 1.18 \\
\hline CIP Tanzania & 1.44 & 1.48 & 1.46 & 1.28 & 1.33 & 1.31 \\
\hline WA Gabolige & 0.92 & 0.87 & 0.89 & 1.50 & 1.44 & 1.47 \\
\hline TIS 2532.OP.1.13 & 0.88 & 1.00 & 0.94 & 0.63 & 0.70 & 0.67 \\
\hline TIS $86 / 00356$ & 2.02 & 2.02 & 2.02 & 1.29 & 1.44 & 1.37 \\
\hline POP Mean & 1.21 & 1.26 & 1.23 & 1.13 & 1.16 & 1.15 \\
\hline \multicolumn{7}{|l|}{ FLSD $(0.05)$} \\
\hline VAR: & 0.0 .17 & 0.0 .16 & & & & \\
\hline POP: & 0.008 & 007 & & & & \\
\hline VAR X POP & 0.21 & 0.19 & & & & \\
\hline
\end{tabular}

POP:= Position of planting

Table 10: Number of pods per plant of pigeonpea intercropped with sweet potato and its grain yield in 2006 and 2007 at Otobi

\begin{tabular}{|c|c|c|c|c|c|c|}
\hline \multirow[b]{2}{*}{ Cropping system/Position of planting } & \multicolumn{3}{|c|}{ Number of pods per plant } & \multicolumn{3}{|c|}{ Grain yield (t/ha $\left.{ }^{-1}\right)$} \\
\hline & 2006 & 2007 & Mean & 2006 & 2007 & Mean \\
\hline Pigeonpea by side of Ogege & 43.50 & 57.00 & 50.25 & 0.97 & 1.27 & 1.12 \\
\hline Pigeonpea by side of CIP Tanzania & 37.50 & 48.67 & 43.09 & 0.70 & 0.95 & 0.83 \\
\hline Pigeonpea by side of WA Gobolige & 39.33 & 51.50 & 45.42 & 0.52 & 0.70 & 0.61 \\
\hline Pigeonpea by side of TIS 2536 OP.1.13 & 36.83 & 48.50 & 42.67 & 1.33 & 1.73 & 1.53 \\
\hline Pigeonpea on top with Ogege & 47.00 & 61.00 & 54.00 & 0.87 & 1.16 & 1.02 \\
\hline Pigeonpea on top with TIS $87 / 0087$ & 57.50 & 74.67 & 66.09 & 1.35 & 1.75 & 1.55 \\
\hline Pigeonpea on top with CIP Tanzania & 41.67 & 54.17 & 47.92 & 0.92 & 1.22 & 1.07 \\
\hline Pigeonpea on top with WA Gobolige & 31.83 & 41.83 & 36.83 & 0.67 & 0.89 & 0.78 \\
\hline Pigeonpea on top with TIS 2536 OP.1.13 & 36.67 & 48.00 & 42.34 & 1.04 & 1.37 & 1.21 \\
\hline Pigeonpea on top of ridge & 65.17 & 84.67 & 74.92 & 1.07 & 1.43 & 1.25 \\
\hline Mean & 58.67 & 72.50 & 65.59 & 1.17 & 1.54 & 1.35 \\
\hline FLSD $(0.5)$ & 2.95 & 8.30 & & 0.15 & 0.13 & \\
\hline
\end{tabular}

Table 11: Land equivalent ratio (LER) and Competitive ratio (CR) of Sweet potato varieties intercropped with pigeonpea at Otobi in 2006 and 2007.

\begin{tabular}{|c|c|c|c|c|c|c|c|c|c|}
\hline \multirow[b]{3}{*}{ Cropping System/Position of planting } & \multirow{2}{*}{\multicolumn{3}{|c|}{ LER }} & \multicolumn{6}{|c|}{ CR } \\
\hline & & & & \multicolumn{3}{|c|}{ Sweet potato } & \multicolumn{3}{|c|}{ Pigeonpea } \\
\hline & 2006 & 2007 & Mean & 2006 & 2007 & Mean & 2006 & 2007 & Mean \\
\hline Pigeonpea by side of Ogege & 1.56 & 1.17 & 1.52 & $\mathbf{0 . 3 3}$ & 0.29 & 0.31 & 0.66 & 0.74 & 0.70 \\
\hline Pigeonpea by side of $87 / 0087$ & 1.71 & 1.62 & 1.67 & 0.23 & 0.20 & 0.22 & 0.98 & 1.11 & 1.05 \\
\hline Pigeonpea by side of CIP Tanzania & 2.34 & 2.99 & 2.67 & 1.05 & 1.37 & 1.21 & 0.21 & 0.16 & 0.19 \\
\hline Pigeonpea by side of WA Gobolige & 0.81 & 0.67 & 0.74 & 0.31 & 0.17 & 0.24 & 0.70 & 1.28 & 0.99 \\
\hline Pigeonpea by side of TIS 2536 OP.1.13 & 1.57 & 1.45 & 1.58 & 0.31 & 0.18 & 0.25 & 1.43 & 1.89 & 1.66 \\
\hline Pigeonpea by side of TIS $86 / 00356$ & 1.32 & 1.25 & 1.29 & 0.37 & 0.34 & 0.36 & 0.59 & 0.66 & 0.63 \\
\hline Mean & 1.55 & 1.58 & 1.57 & 0.43 & 0.43 & 0.43 & 0.76 & 0.97 & 0.87 \\
\hline Pigeonpea on top with Ogege & 1.59 & 1.47 & 1.53 & 0.30 & 0.26 & 0.28 & 0.73 & 0.85 & 0.79 \\
\hline Pigeonpea on top with TIS 87/0087 & 2.28 & 2.22 & 2.25 & 0.25 & 0.26 & 0.26 & 0.87 & 0.85 & 0.86 \\
\hline Pigeonpea on top with CIP Tanzania & 2.81 & 2.33 & 2.57 & 0.74 & 0.57 & 0.66 & 0.30 & 0.39 & 0.35 \\
\hline Pigeonpea on top with WA Gobolige & 1.13 & 1.00 & 1.07 & 0.26 & 0.19 & 0.23 & 0.84 & 1.14 & 0.99 \\
\hline Pigeonpea on top with TIS 2536 OP.1.13 & 1.62 & 1.50 & 1.56 & 0.21 & 0.18 & 0.20 & 1.08 & 1.23 & 1.16 \\
\hline Pigeonpea on top with TIS $86 / 00356$ & 1.68 & 1.63 & 1.66 & 0.34 & $\mathbf{0 . 3 3}$ & 0.34 & 0.65 & 0.66 & 0.66 \\
\hline Mean & 1.85 & 1.69 & 1.77 & 0.35 & 0.30 & 0.33 & 0.75 & 0.85 & 0.50 \\
\hline FLSD (0.05) & 0.26 & 0.18 & & & & & & & \\
\hline \multicolumn{10}{|l|}{ Paired t-test $(0.05)$} \\
\hline Sweeet potato vs pigeonpea (2006) - CR & & & & & & $2.20 *$ & & & \\
\hline Sweet potato vs pigeonpea (2007) - CR & & & & & & $47 *$ & & & \\
\hline
\end{tabular}

*:Significant at $5 \%$ probability level

NS:Not significant. 
Table 12: Yield of Sweet potato Var. TIS 87/0087 intercropped with pigeonpea on ten farmers' fields in villages around Otobi in 2007.

\begin{tabular}{|c|c|c|c|c|c|c|}
\hline \multirow[b]{3}{*}{ Location } & \multicolumn{4}{|c|}{ Yield $\left(\mathrm{t} \mathrm{ha}^{-1}\right)$} & \multirow{3}{*}{$\begin{array}{l}\text { Willingness to } \\
\text { adopt practice by } \\
\text { farmers }\end{array}$} & \multirow[t]{3}{*}{ Remarks by farmers } \\
\hline & \multicolumn{2}{|c|}{ Top } & \multicolumn{2}{|c|}{ Side } & & \\
\hline & Sweet potato & $\begin{array}{c}\text { Pigeonpe } \\
\text { a }\end{array}$ & $\begin{array}{c}\text { Sweet } \\
\text { potato }\end{array}$ & Pigeonpea & & \\
\hline Omebe & 11.91 & 1.20 & 10.50 & 1.30 & Yes & Top planting preferred \\
\hline Omebe & 14.22 & 1.00 & 11.34 & 1.22 & Yes & Prefer top planting \\
\hline Akwete & 12.53 & 1.40 & 11.33 & 1.31 & Yes & Prefer side planting \\
\hline Allan & 15.20 & 0.95 & 12.50 & 1.42 & Yes & Top planting preferred \\
\hline Allan & 12.64 & 1.10 & 12.20 & 1.33 & No & Practice is strange \\
\hline Oko-Otobi & 13.10 & 1.23 & 11.55 & 1.30 & Yes & Top planting preferred \\
\hline Oko-Otobi & 14.10 & 1.10 & 13.00 & 0.95 & Yes & Top planting preferred \\
\hline Igbudu-eke & 16.40 & 0.85 & 14.22 & 1.22 & Yes & Top planting preferred. \\
\hline Igbudu-eke & 11.50 & 1.20 & 10.55 & 1.21 & Yes & Side planting preferred. \\
\hline Ijami-Otobi & 13.60 & 1.00 & 12.22 & 1.22 & No & Pigeonpea harvesting is tedious. \\
\hline \multicolumn{7}{|c|}{ Paired t-test $(0.05)$} \\
\hline \multicolumn{3}{|c|}{ Sweet potato (Top Vs Side) } & \multicolumn{4}{|c|}{$6.40 *$} \\
\hline \multicolumn{3}{|c|}{ Pigeonpea (Top Vs Side) } & \multicolumn{4}{|c|}{$-2.34^{\mathrm{ns}}$} \\
\hline
\end{tabular}

\section{DISCUSSION}

The reduction observed in the total fresh and saleable root yields of sweet potato varieties intercropped with pigeonpea in this study might have resulted from depression of photosynthesis due to decrease in solar radiation by shading of the sweet potato by the taller pigeonpea component. Fujita and OfosuBudu (1996) had indicated that when component legume is taller than non-legume, the legume can grow well due to high photosynthetic and high biological nitrogen fixation activities with adequate solar radiation and that the non-legume growth is severely suppressed due to depression of photosynthesis through decreases in irradiance. The superior performance of TIS 87/0087 under both cropping systems in total fresh and saleable root yields over the other varieties was similar to the reports of earlier studies (Njoku et al., 2007; Onunka, 2006; Okorie and Okpala, 2000). This implied that TIS $87 / 0087$ might be more tolerant of shading and therefore more suitable for intercropping with pigeonpea in either of the planting positions tested. The differential performance of the varieties of intercropped sweet potato at the two planting positions of pigeonpea indicated that no single planting position could be recommended over the others for the varieties tested. However, such varieties as TIS 87/0087, Ogege and CIP Tanzania could be intercropped with pigeonpea, using either of the planting positions. The reasons for better performance of Sweet potato varieties at a particular planting position under intercropping with pigeonpea might need further investigation.

Although no consistent result was obtained for both years, the higher number of pods per plant and grain yield of sole pigeonpea over intercropped pigeonpea in 2006 might be due to interplant competition for natural growth resources such as soil nutrients and water by both intercrop components. It is known that competitive reactions reduce yields in intercropped crop species as compared with mono cropping (Egbe, 2007). The non-significant result obtained in sole vs intercropping in 2007 for the number of pods per plant and grain yield of pigeonpea could be possible. Fujita and Ofosu-Budu (1996) had reported that when component legume was taller than nonlegume, biomass production of intercropping approached that of mono cropping of legume.

The LER of Sweet potato varieties intercropped with pigeonpea at the two planting positions were all above 1.0, except the combination of WA Gabolige and pigeonpea, indicating that greater productivity per unit land area was achieved by growing the two crops together than by growing them separately. These results showed that genotypic compatibility might exist between the sweet potato varieties and pigeonpea. Ali (1996) had stated that identification of suitable genotypes of the component crops was necessary for complementarity. Njoku et al. (2007) obtained similar results in sweet potato + Okro intercropping in Southeastern Nigeria. The results further revealed that WA Gabolige and pigeonpea would give higher productivity when grown separately than when intercropped and the two might therefore not be compatible for intercropping. The LER figures in this intercropping study were high depicting high yield advantages derived. This was probably because sweet potato serving as cover crop conserved soil moisture reduced soil temperature and added organic matter to the soil, while pigeonpea added organic matter through leaf litter production and biologically fixed nitrogen for the benefit of the intercropping systems.

Competitive ratio (CR) could be useful in comparing the competitive ability of 
the different crops and it may help clarify the nature of competition between component crops (Egbe, 2005). Pigeonpea proved more competitive than the sweet potato varieties in this study, probably because it was taller. Generally, biomass production of shorter component crops is reduced by depression of photosynthesis due to decreases in solar radiation.

Snapp and Silim (2002) in their study on farmer preferences and legume intensification for low nutrient environment in Africa had indicated that research intended to translate benefit to smallholder farmers must keep farmer preferences and belief systems in the fore. The results obtained in this study pointed to the potential benefits and possible sustainability benefits of the Sweet potato + pigeonpea intercropping among farmers in Southern Guinea Savanna.

\section{REFERENCES}

Adam, K.L. (2005). Sweet potato: Organic production. http://attra.ncat.org/attrapub/sweetpotato.html

Ali, M. (1996). Pigeonpea-based cropping systems in the Semi-Arid Tropics. In: Ito, O., Katayama, K., Johansen, C., Kumar Rao, J.V.D.K., Adu-Gyamfi, J.J. and Rego, T.J. (eds). Roots and nitrogen in cropping systems of the Semi-Arid Tropics.JIRCAS Ohwashi, Tsukuba, Ibaraki 305, Japan. Pp 4158.

Anders, M.M., Potdar, M.V., Francis, C.A. (1996). Significance of intercropping in cropping systems. In Ito O., Katayama, K., Johansen, C., Kumar Rao, J.V.D.K., Adu-Gyamfi, J.J. and Rego, T.J. (eds). Roots and nitrogen in cropping systems of the Semi-Arid Tropics. JIRCAS, Ohwashi, Tukuba, Ibaraki 305, Japan. Pp 1-18.

BNARDA (2007). Benue State Agricultural and Rural Development Authority: Annual Report for 2007 Makurdi, Nigeria.

Egbe, O.M. (2005). Evaluation of agronomic potentials of some pigeonpea genotypes for intercropping with maize and sorghum in Southern Guinea Savanna of Nigeria. Ph.D thesis, University of Agriculture, Makurdi, Nigeria.

Egbe, O.M.and Kalu, B.A. (2006). Farming System Study: Participatory Rural Appraisal of Pigeonpea Cropping Systems in Southern Guinea Savanna of Nigeria. J. on Environ. (Abia State
University Environmental Review) 5(1): 37-47.

Egbe, O.M.and Adeyemo, M.O. (2006). Estimation of the effects of intercropped pigeonpea on the yield and yield components of maize in Southern Guinea Savanna of Nigeria. J. of Sustain. Dev. in Agric. and Environ. 2: 107-119.

FAO (2004). Food and Agricultural Organisation of the United Nations. Production Year Book. FAO Rome. Vol. 40: pp 307.

Fujita, K .and Ofosu-Budu, K.G. (1996). Significance of intercropping in cropping systems. In: Ito, O., Katayama, K., Johansen, C., Kumar Rao, J.V.D.K., Adu-Gyamfi, J.J. and Rego, T.J. (eds). Roots and Nitrogen in Cropping Systems of the SemiArid Tropics. JIRCAS International Agricultural Series No.3, Ohwashi, Tukuba, Ibaraki, 305, Japan. Pp 1440.

GENSTAT (2003). GENSTAT Release 4.23 (Copyright 2003) Lowes Agricultural Trust Rothamsted Experimental Station.

Gomez, K.A.and Gomez, A.A. (1984). Statistical procedures for agricultural research. $2^{\text {nd }}$ ed. John Willey \& Sons, Toronto, ON, Canada.

Kowal, J.M. and Knabe, D.T. (1972). An agroclimatological atlas of the Northern States of Nigeria with explanatory notes. Ahmadu Bello University Press, Zaria.

Njoku, S.E., Muoneke, C.O., Okpara, D.A.and Agbo, F.M.O. (2007). Effect of intercropping varieties of sweet potato and Okra on Ultisol of Southeastern Nigeria. African J. of Biotech. 6(14): 1650-1654.

Obi, I.U. (1990). Statistical method of detecting differences between treatment means. SNAAP Press (Nig.) Ltd., Enugu, Nigeria pp 1-14.

Okorie, P.E.and Okpala, E. (2000). Effect of animal manure and inorganic fertilization on ground flora development at two degraded sites in Umudike, Nigeria J. Sustain. Agric. Environ. 1(2): 84-89.

Onunka, N.A .(2006). Varietal response of three sweet potato varieties to different rates of a mixture of organic and inorganic fertilizer. 2006 Annual Report of the National Root Crops Research Institute (NRCRI), Umudike, Nigeria. Pp 136-138. 
Agronomic Assessment of Some Sweet Potato Varieties

Putnam, D.H., Herbert, S.J.and Vargas, A. (1984). Intercropped corn soyabean density studies. 1. Yield complementarity. Expl. Agric. 21: 41-51.

Snapp,S.S.and Silim,S.N.(2002).Farmer preferences and legume intensification for low nutrient environments. Plant and Soil.245(1):181-192
Udealor, A., Ezulike, T.O., Nwauzor, E.C., Asumugha, G.N.and Amaefula, A. (2006). Evaluation of different sweet potato varieties under different intercropping systems. 2006 Annual Report of the National Root Crops Research Institute (NRCRI), Umudike, Nigeria. Pp 226-228 
Agro-Science Journal of Tropical Agriculture, Food, Environment and Extension Volume 8 Number 2 Mav 2009 pp $84-89$

ISSN 1119-7455

\title{
INCOME AND CROP DIVERSIFICATION AMONG FARMING HOUSEHOLDS IN A RURAL AREA OF NORTH CENTRAL NIGERIA
}

\author{
Ibrahim, H., Rahman, S.A., Envulus, E.E and Oyewole, S.O \\ Department of Agricultural Economics and Extension Nasarawa State University, Keffi \\ PMB 135,Lafia, Nigeria.
}

\begin{abstract}
Income and crop diversification have been identified as essential strategies for raising income and reducing rural poverty. Both strategies were analyzed based on empirical data collected from rural households. The analysis was done using the Simpson Index of Diversity (SID) and Ordinary least square (OLS) regression analysis. The results revealed that diversification into a number of income sources and crops grown were very high. The determinants of income diversification were number of children less than 12 years old, number of adults above 60 years old, availability of electricity in the household and distance from local market. The determinants of crop diversification were, age and level of education of the household head, number of extension visits, availability of tractor hiring services and returns from crop production. Most households occupations in the study area were no longer agriculture based, however there willingness to diversify was significantly influenced by their socioeconomic characteristics.
\end{abstract}

Key words: Income, Crop, Diversification, Rural area, Households

\section{INTRODUCTION}

Income diversification refers to an increase in the number of sources of income or the balance among the different sources. Thus, a household with two sources of income would be more diversified than a household with just one source, and a household with two income sources, each contributing half of the total, would be more diversified than a household with two sources, with one that accounts for $90 \%$ of the total (Joshi, et al; 2003). Income diversification is defined as the process of switching from low value crop production to a higher value crop, livestock and non-farm activities. "High value crops" are often defined in terms of the value per unit of weight; it is probably more useful to define them as crops that generate high economic return per unit of labour and land. Income growth in an agricultural economy can come from various resources. Distinction can be made between growth in crop income, non-crop agriculture income (livestock, fisheries, and forestry) and non-agriculture income which includes both off-farm wage labour and nonfarm self employment (Escobal, 2001). Given that semi subsistence farmers often focus on production of staple food crops, the switch to non-crop activities is often referred to as income diversification. Crop diversification refers to growing many crops at the same time. It is also concerned with the switch from subsistence food production to commercial agriculture.
Rural households in many different countries have been found to diversify their income sources allowing them to spread risk and smoothen consumption (Chibnik, 1994; Ellis, 1998; Reardon, Delgado and Milton, 1992; Valdivia, Dunn and Jette, 1996). This is often necessary in agriculture based peasant economies because of risks such as variability in soil quality, household and crop diseases, price shock, unpredictable rainfall and other weather related events.

Income diversification can be achieved by producing a variety of crops and/or pursuing off-farm employment. According to the World Bank (1996), 52\% of Nigerians live on less than a dollar per day. In addition to the high incidence of poverty, most rural areas of the world are characterized by poor infrastructure, low level of urbanization, low population density and a very important agricultural sector (Minot, Epprecht, Anh and Trung, 2006). In addition to a rapid economic growth, a sustained and widespread growth in household income through diversification is a necessary condition for any developmental strategy for such areas (Minot et al., 2006). The aim of this study was to provide information that will assist policy makers in designing rural development and public investment policies that will help rural households raise their income through diversification. The specific objectives were to (i) examine the diversity in income sources of 
the households; (ii) examine the diversity in crop production of the households; and (iii) identify the determinants of crop and rural income diversification.

\section{MATERIALS AND METHODS}

The study was carried out in Nasarawa Eggon area in the North central Nigeria. The area is comprised of five districts namely Umme, Alogani, Alizaga, Agungi and Nasarawa Eggon with an estimated land of about $2035 \mathrm{sq} \mathrm{km}$. The area lies approximately between latitude $7^{\circ}$ and 9 North and longitude $7^{0}$ and 10 East. It has a projected population of about 89,787 people (NPC, 2005). About 70\% of the population is made up of subsistence farmers who cultivate crops such as yam, maize, sorghum, millet, and cowpea. The climate of the area is of the savannah type with two major seasons; the rainy season starting from the late April to late October and a dry season, which starts with harmattan from early November to late March. Primary data were used for the study and were collected with the aid of an interview schedule administered by trained enumerators to 100 household heads selected from the five districts in the study area i.e. 20 households heads per district. The households were earlier identified from a reconnaissance survey to have at least two income sources. Data were collected on socio economic variables, income and income sources and types of crops grown over a period of one month.

\section{Analytical techniques}

The Simpson index of diversity:

The Simpson index of diversity (SID) is widely used to measure the biodiversity of an ecosystem and is expressed as follows;

$\mathrm{SID}=1-\sum \mathrm{p}_{\mathrm{i}}^{2}$

Where;

$\mathrm{p}_{\mathrm{i}}=$ proportion of organisms classified in a species.

$\Sigma=\quad$ Summation sign

The SID can also be interpreted as the probability that two randomly selected organisms will be from the same species. Joshi et al (2003) adopted the SID to compare crop diversification in several South Asian countries. In this study, it was used to measure income and crop diversity, interpreting $\mathrm{p}_{\mathrm{i}}$ as the proportion of income from source "i" or crop "i". If there is just one crop or source of income, $p_{i}=1$ and SID $=0$. As the number of crops/income sources increases, the share " $p_{i}$ " declines as does the sum of the squared share, so that SID approaches 1 . If there are $\mathrm{K}$ sources of income then SID falls between zero and $1-1 / \mathrm{K}$. The closer SID is to zero, the more the specialization, and the further it is from zero, implies the more the diversification.

\section{Multiple regression analysis:}

Multiple regression analysis was used to identify the determinants of income and crop diversification. Two separate regression models were specified in their explicit forms as follows;

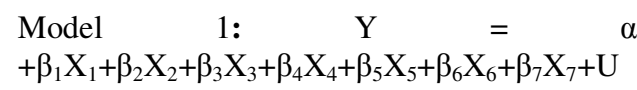
Where:

$$
\begin{aligned}
\mathrm{Y}= & \text { number of income sources in the } \\
& \text { household (actual number) } \\
\alpha= & \text { constant term } \\
\beta_{1}-\beta_{7}= & \text { regression coefficients } \\
\mathrm{X}_{1}= & \text { age of household head (years) } \\
\mathrm{X}_{2}= & \text { years of education of household } \\
& \text { head (no. of years) } \\
\mathrm{X}_{3}= & \text { total farm size of household (ha) } \\
\mathrm{X}_{4}= & \text { number of children under } 12 \\
& \text { years old (actual number) } \\
\mathrm{X}_{5}= & \text { number of adults over } 60 \text { years } \\
& \text { old (actual number) } \\
\mathrm{X}_{6}= & \text { availability of electricity in the } \\
& \text { household (dummy: yes }=1, \\
& \text { No=0) } \\
\mathrm{X}_{7}= & \text { distance from a local market } \\
& (\text { Km) } \\
\mathrm{U}= & \text { error term }
\end{aligned}
$$

Model 2: $Y=\alpha+\beta_{1} X_{1}+\beta_{2} X_{2}+\beta_{3} X_{3}+\beta_{4} X_{4}$ $+\beta_{5} \mathrm{X}_{5}+\beta_{6} \mathrm{X}_{6}+\beta_{7} \mathrm{X}_{7}+\beta_{8} \mathrm{X}_{8}+\beta_{9} \mathrm{X}_{9}+\mathrm{U}$

Where;

$\mathrm{Y}=$ number of crops grown (actual number)

$\alpha=$ constant term

$\beta_{1}-\beta_{9}=$ regression coefficients

$\mathrm{X}_{1}=$ age of household head (years)

$\mathrm{X}_{2}=$ membership of cooperative society

By household head (years)

$\mathrm{X}_{3}=$ years of education household head (no. of years)

$\mathrm{X}_{4}=$ total household farm size (ha)

$\mathrm{X}_{5}=$ extension visit (number of times/month)

$\mathrm{X}_{6}=$ distance to a local market $(\mathrm{Km})$

$\mathrm{X}_{7}=$ availability of tractor hiring services (dummy: yes $=1$, no $=0$ )

$\mathrm{X}_{8}=$ annual returns from crop production (

$\mathrm{X}_{9}=$ road condition $($ dummy: $\operatorname{good}=1, \mathrm{bad}=$ $0)$

$\mathrm{U}=$ error term

It is assumed that for a given observation, the error term (U) is a random variable with a probability distribution that is normal with a mean of zero and a constant standard deviation. The linear, semi-log and double $\log$ forms of the 2 models were tried and the lead equation (linear form) was selected based on the $\mathrm{R}^{2}$, $\mathrm{t}$ - statistics and the 
conformity of the sign of the estimated coefficients with apriori expectations.

\section{RESULTS AND DISCUSSION Diversity in sources of income}

To examine the diversity of income sources, household income was divided into five categories: crop, livestock, fisheries, nonfarm enterprises and wage income. The simplest measure of income diversity was the average number of income sources (of the five listed here) that households had. It was observed that rural households in the study area had an average of 2 sources of income (Table 1). The value of the SID was 0.82 . This is indicative of the fact that diversification was high as respondents adopted multiple income generating activities to manage risk and meet household consumption needs. In order words, households in the study area showed a tendency to increase the number of sources of income and the balance of income among sources. Carrying out two activities on the same farm might reduce cost of increased output if they are linked in the same way, because the production of one good reduces the unit cost of producing another good. For example, a household that raises livestock can often reduce the cost of feed by growing its own grain and fodder; raising livestock near crop reduces the cost of producing crops by providing an inexpensive source of organic fertilizer (Minot et al., 2006).

\section{Diversity in crop production}

The average number of crops grown out of the ten observed in the study area was five. This agrees with the findings of Minot et al. (2006) that rural households grow up to five or six crops. The findings in Table 1 indicated non-specialization among the respondents. The aim is to meet consumption needs, to reduce risk associated with weather or disease outbreak or for economy of scale. The SID value of 0.94 is further supportive of the above observation.

Table 1: Measurement of diversity in income sources and crop production

\begin{tabular}{lll}
\hline & Income sources & Crops grown \\
\cline { 1 - 2 } SID & Average number & \\
& 2 & 5 \\
& 0.82 & 0.94 \\
\hline
\end{tabular}

Determinants of income diversification From the regression analysis on Table $2,63 \%$ of the variation in the number of income sources was explained by the variables included in the model. The number of children less than 12 years had a positive but significant coefficient. As expected, households with a small proportion of children under 12 years tended to have a larger number of income sources. Controlling for farm size, the marginal product of additional family labour in crop production declined as the household size increased, making it more likely that alternative source of income would be attractive. Furthermore with a large number of working age adults, it is more likely that the household will have a range of skills and inclination that allowed income diversity at the household level, even if household members are specialized individually (Minot et at., 2006).

Table 2: Determinants of Income diversity

\begin{tabular}{llll}
\hline Variables & $\begin{array}{l}\text { Regression } \\
\text { Coefficient }\end{array}$ & $\begin{array}{l}\text { Standard } \\
\text { Error }\end{array}$ & T value \\
\hline Constant term & 2.256 & 0.406 & 0.00 \\
Age of household & 0.642 & 0.008 & $0.408^{\mathrm{NS}}$ \\
Years of education Household & -1.058 & 0.13 & $0.936^{\mathrm{NS}}$ \\
Head & 1.593 & 0.187 & $0.519^{\mathrm{NS}}$ \\
Total farm size of Household & 0.282 & 0.055 & $0.86^{* * *}$ \\
Number of children under 12 & -4.026 & 0.062 & $0.002^{*}$ \\
Number of adult above 60 years & -2.157 & 0.182 & $0.066^{* * *}$ \\
Availability of electricity & & & \\
in the Household & -9.693 & 0.012 & $0.000^{*}$ \\
Distance from local market & & & \\
\hline
\end{tabular}

$\mathrm{R}^{2}=0.63$

F- Ratio $=83 * * *$

The number of adults above 60 years was also significant. The negative sign implies that larger households with small proportion of elderly people tended to have a larger number of income sources. A large household with a high proportion of working age adults implies more labour for income generating activities. If this labour is allocated to crop production, the higher labour intensity will probably be reflected in higher yield and greater per hectare crop income (Joshi et al., 2003). Availability of electricity in the household was significant but negatively related to the number of income sources. Electricity makes it possible for household members to participate in some form of self-employment. Thus, households with electricity have more diverse income sources and a larger share of income from nonfarm activities. A household with electricity should earn more of its income from non-farm activities than one without it. Distance to local 
Income and Crop Diversification Among Farming Households

Table 3: Determinants of crop diversity (number of crops grown)

\begin{tabular}{llll}
\hline Variables & Regression Coefficient & Standard Error & T value \\
\hline Constant term & 6.247 & 0.768 & 0.000 \\
Age of Household Head & 2.201 & 0.015 & $0.085^{* * *}$ \\
Membership of cooperative & -4.641 & 0.059 & $0.436^{\text {NS }}$ \\
Education of Household Head & 6.270 & 0.030 & $0.037^{* *}$ \\
Total farm size & 0.122 & 0.138 & $0.378^{\text {NS }}$ \\
Extension visit) & 7.739 & 0.255 & $0.005^{*}$ \\
Distance to local market & -1.634 & 0.025 & $0.513^{\text {NS }}$ \\
Available of tractor hiring & 0.614 & 0.429 & $0045^{* *}$ \\
Return from crop production & -2.228 & 0.000 & $0.095^{* * *}$ \\
Road net work condition & -1.068 & 0.405 & $0.010^{*}$ \\
\hline
\end{tabular}

$\mathrm{R}^{2}=0.49$

F-Ratio $=9 *$

$*=$ Significant at $10 \%$ level

$* *=$ Significant at $5 \%$ level

$* * *=$ Significant at $1 \%$ level

$\mathrm{NS}=$ Not significant

market was significantly related to income diversification. The negative sign implies that the larger the distance the lesser the tendency of households to diversify and vice versa. Households with poor access to market face higher transaction cost in buying from or selling to the national economy (Omamo,

1998). It is expected that households that have poor market access to be more specialized in crop production, have fewer non-farm activities and fewer income sources. Since transaction cost reduces the return from market sale, it is expected that remote households will get a smaller share of the crops produced. The education of household head was not significant even though previous studies (Pedersen and Annou 1999; Joshi et al., 2003; Minot et al., 2006) had confirmed that education may open the door to a number of different economic activities, either because of formal requirement for wage earning position or because education facilitates learning about new self employment opportunities. Farm size had a positive relationship with diversification but was also not significant

\section{Determinants of Crop Diversification}

From the regression analysis on Table $3,49 \%$ of the variation in the number of crops grown was explained by the variables included in the model. The number of crops grown increased with the age of the household head. This seems to indicate that farmers try new crops as they gain more experience overtime. The educational level of household heads was positively related with the number of crops grown, thus highlighting the importance of knowledge and ability to absorb new information through extension services or other sources. As the number of years of education of the household's head increases so

does his work related skills and his ability to acquire new skills. Thus, it is expected that a high level of education will lead to a higher value crop production and more commercially oriented agriculture and greater participation in non-farm activities.

Increase in the frequency of extension visits implies that the more the household head has contact with extension agents, the more the tendency to diversify into crop production. This also implies that extension workers have an important role to play in creating awareness among farmers as well as educating them on the importance of diversification. The availability of tractor for the household also related positively and significantly with the number of crops grown. This means that the more the household head has tractor available for hire, the less the requirement for manual labour and the greater the extent of diversification. Household heads that have access to tractor should earn more from crop production as a result of the reduced drudgery of land preparation.

The higher the income derived from crop production by the household's head the more the tendency to diversify into crop production. An increase in the share of crop production was associated with lesser income diversity (as household specialized in crop production). A household with bad access roads face higher transaction cost in buying from or selling to markets. Since wage labour and non-farm enterprises are almost all market oriented, crop production can be for home consumption or for sale. As transaction cost reduces the returns from market sale it is expected that remote households will sell a smaller share of their crop production (Minot, 1999). Finally it is expected that remote households will have more diverse cropping pattern to meet diverse needs of household consumption. If a household head lives near a road that is impassible (bad road) he sells less crop output compared to a household head living near a road that is passable (good road) all season (Minot et al., 2006). Good road 
network also favours diversification because of low marketing cost, easy disposal of commodity, reduced risk and post harvest loses. High profit implies less diversification to other crops while lesser profit may induce farmers to diversify into new crops with an anticipated higher return. This is collaborated by the findings of Joshi et al. (2003).

\section{CONCLUSION AND RECOMMENDATIONS}

The study has shown that diversification into a number of income sources and crops grown are very high in the study area. Diversification can also help to relax credit or capital constraints among farmers. Similarly, the socio-economic characteristics of the respondents such as number of children under 12 years, number of adults above 60 years, availability of electricity in the household and distance from a local market influence the level of income diversification. Furthermore, the age and level of education of the household head, extension contact, availability of tractor hiring services, returns from crop production and road condition significantly determine the level of crop diversification. Based on the findings, the followings are recommended;

1. Policies and programmes to raise the income of the poor households must also focus on increasing the income from crop production. This can be achieved by improving agricultural extension delivery in the country. Therefore, there is a need for the State governments to pay more attention to agricultural extension programmes through the recruitment and training of adequate extension workers to meet the needs of the nation.

2. Programmes to help farmers raise farm income through crop production should also focus on providing tractor hiring services in order to reduce drudgery and to increase the hectarage and income of the poorest households.

3. There is a need for government to provide more rural roads and rehabilitate bad ones in order to reduce the high transaction cost of buying from or selling to markets, as transaction cost reduces the returns from market sales.
4. Power supply to rural areas should be clearly articulated in the power supply component of the seven point agenda of the Federal Government. This will go along way to aid the setting up of cottage industries and the creation of non-farm employment opportunities.

\section{REFERENCES}

Chibnik, M. (1994) Risky Rivers: The Economics and Politics of Flood Plain Farming in Amazonia. University of Arizona Press. Tuscon

Ellis, F. (1998) Household livelihood strategies and rural livelihood diversification Journal of Development Studies, 35(1):1-38

Ersado, L. (2003) The determinants of nonfarm income diversification in rural Peru. World Development 29(30): 497-508

Escobal, J. (2001) The determinants of nonfarm income diversification in rural Peru. World Development, 29(30):497-508

Joshi, P.K., Gulati, A.A., Birthal, P.S. and Twari, L. (2003) Agriculture diversification in South Asia: Pattern, determinants and policy implications. Discussion Paper No. 57. Market structure studies division. International Food Policy Research Institute. Washington D.C.

Minot, N. (1999) Effectiveness of transaction cost on supply response and market surplus: Simulation using nonseparable household models. Discussion paper No. 36. Market Structure Studies Division, International Food Policy Research Institute Washington D.C.

Minot, N., Epprecht., M., Anh., T.T.T. and Trung, L.Q. (2006) Income diversification in the northern uplands of Vietnam': Research report No. 145. International Food Policy Research Institute, Washington D.C.

National Population Commission, (2005) National Population and Housing Census Report Federal Republic of Nigeria 
Income and Crop Diversification Among Farming Households

Omamo, S. (1998) Transport costs and smallholder cropping choices: An application to Siaya District,

Kenya. American Journal of Agricultural Economics, 80(February):116-123

Pedersen, G. and Annou, M. (1999) Rural household income diversification in Vietnam. Quarterly Journal of International Agriculture, 38(2):140149

Reardon. T., Delgado, D and Milton, P. (1992) Determinants and effects of income diversification amongst farm households in Burkina Faso. Journal of Devt. Studies, 28(20):264-296
Valdivia. C., Dunn, E. and Jette, C. (1996) Diversification as a risk management strategy in an Andean agro pastoral community' American Journal of Agric Economics, 78(5):13-34.

World Bank (1996). Poverty in the Midst of Plenty. The challenge of growth with inclusion. A world Bank poverty assessment, population and human resource division. West Africa Department, African Region Report No 14733. 
Agro-Science Journal of Tropical Agriculture, Food, Environment and Extension Volume 8 Number 2 May 2009 pp $90-96$

ISSN 1119-7455

\title{
MEASUREMENT OF TECHNICAL EFFICIENCY AND ITS DETERMINANTS IN CROP PRODUCTION IN LAFIA LOCAL GOVERNMENT AREA OF NASARAWA STATE, NIGERIA
}

\author{
Rahman, S.A. and Umar H.S. \\ Department of Agricultural Economics and Extension Nasarawa State University, Keffi, Lafia \\ Campus, Lafia, Nigeria.
}

\begin{abstract}
This study was designed to measure technical efficiency and identify its determinants in crop production in Lafia Local government Area of Nasarawa State of Nigeria using a stochastic frontier production model. Double stage random sampling technique was used to select 100 crop farmers from which input-output data were collected based on 2005 cropping season. The results revealed that sixty five percent (65\%) of the farmers were within the age range of 31-50 years and $67 \%$ had farm size ranging from 2-4 hectares. The technical efficiency of crop production range from $32.7 \%$ to $89.4 \%$ with mean of $69.6 \%$. Farm size and fertilizer were the major inputs that are associated with the variation in crop output. The significant socio economic variables that accounted for the observed variations in technical efficiency among crop farmers were age, gender, marital status, household size, other occupation and land ownership. It is therefore recommended that a land redistribution policy that will increase the farm size of the farmers should be initiated. Fertilizer supply at subsidized rate to farmers in the area should be encouraged.
\end{abstract}

Key words: Technical Efficiency, Determinants, Crop Production.

\section{INTRODUCTION}

Efficiency measurements have been attempted in several studies (Shanmugan and Palanisami, 1993; Jayaram et al., 1989; Hang and Bagi, 1984; Kalirajan, 1981 and Junakar, 1980). There are two approaches to efficiency measurement; these are parametric stochastic frontier production function and the non parametric mathematical programming, commonly referred to as Data Envelopment Analysis (Sharma et al 1999, Charnes et al., 1978, Aigner et al., 1977 and Meeusen and Broeck, 1977).

In the stochastic frontier production function approach, an efficient farm is said to operate on the production frontier while inefficient farms are those operating below the production frontier. A technically efficient farm produces the maximum possible output from inputs used, given locational and environmental constraints and it minimizes resources used for any given level of output (Rahman et al., 2005). Several factors including socio-economic and demographic factors, farm plot level characteristics, environmental factor and non-physical factors are likely to affect the efficiency of small holding farmers. Parikh et al (1995), used stochastic cost frontier to analyze Pakistani agriculture in a two-stage estimation procedure. They found that education, number of working animals, credit per acre and number of extension visits significantly increased cost efficiency while large land holding size significantly decreased cost efficiency.

In single estimation approach of the technical efficiency model for Indian farmers, Colli et al (1998), found that years of schooling, land size and age of farmers are positively related to technical efficiency. Seyoum et al (1998) investigated the technical efficiency of maize produce in Ethiopia and compare the performance of farmers within and outside the programme of technology demonstration, using Cobb-Douglas stochastic production functions. Their empirical results showed that farmers that participated in the programme are more technically efficient with mean technical efficiency equal to $94 \%$ compared to $79 \%$ for those outside the project. Thus, most of the empirical studies show that 
socio-economic characteristics and farm characteristics are important sources of technical efficiency among farmers.

This study, therefore, is an attempt aimed at measuring technical efficiency and

(i) describe socio-economic characteristics of the crop farmers;

(ii) estimate input-output relationship in crop production;

(iii) determine technical efficiency in crop production and,

(iv) identify socio-economic factors influencing technical efficiency in crop production.

\section{MATERIALS AND METHODS}

This study was conducted in Lafia Local Government Area of Nasarawa State. The area which is located in South Geopolitical zone of Nasarawa State lies between latitude $08^{0} 33^{1} \mathrm{~N}$, and longitude $08^{0} 32^{1} \mathrm{E}$ and altitude $181.53 \mathrm{~m}$ (Meteorological department, Lafia Nasarawa State, 2005). The average annual rainfall is approximately $1,288 \mathrm{~mm}$ and annual mean temperature range from $22.7^{\circ}$ $36.8^{\circ}$. The soil texture is predominantly sandy-loam. Sorghum, cowpea, rice, maize, sesame, groundnut and cassava are the main crops grown in the area. The Local Government Area has a population of 330,712 people, made up of 169,398 males and 161,314 females (NPC, 2006). A two stage random sampling technique was adopted for this study. In each of the five districts in the study area, two villages were randomly selected. In each of the ten villages selected, ten farmers were randomly sampled, giving rise to a total of one hundred (100) farmers which were used for the study.

Primary data were collected using structured questionnaire. The data were collected for 2005 cropping season. Information collected include labour input, capital inputs, output, prices and farmers' socio-economic characteristics such as age, farming experience, level of education, household size and land ownership. The analysis of data was done by estimation of stochastic frontier production function model.

\section{The Model Specification}

The stochastic frontier function used by Onu et al (2000) and Parikh and Shah (1995) as derived from the error model of Aigner, Lovell and Schmidt (1977) were applied for this study. The stochastic identifying factors determining its magnitude in general crop production in Lafia Local Government Area of Nasarawa State, Nigeria. The specific objectives for this study include to:

production with a multiplicative disturbance term of the farm is shown below:

$\mathrm{Y}=\mathrm{F}(\mathrm{X} \beta) \exp ^{\mathrm{E}}$....

$\mathrm{Y}=$ The value of

farm outputs

$\mathrm{X}=$ Vector of input quantities

$\beta=\mathrm{a}$ vector parameters

$\mathrm{E}=$ Stochastic disturbance term consisting of two independent elements $\mathrm{U}$ and $\mathrm{V}$.

\section{Where}

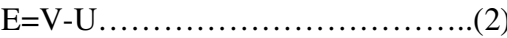

The symmetric component, V, accounts for factors outside the farmers' control, such as weather and diseases. It is assumed to be independent and identically distributed normal random variable $\left(\mathrm{O}, \delta \mathrm{V}^{2}\right)$. A one side component $\mathrm{U} \leq \mathrm{O}$ reflects the technical inefficiency relative to the stochastic frontier, $\mathrm{F}(\mathrm{X} \beta) \mathrm{E}$. The distribution of $\mathrm{U}$ is half normal. The stochastic production frontier model can be used to analyze cross sectional data. The model simultaneously estimates the individual efficiency of the respondent farmers as well as determinants of technical efficiency (Batesse and Coelli, 1995). The frontier of the farm is given by combining (1) and (2).

$\mathrm{Y}=\mathrm{F}(\mathrm{X} \beta) \exp ^{(\mathrm{V}-\mathrm{U})}$

Measures of efficiency for each farm can be calculated as

$\mathrm{TE}=\frac{\mathrm{F}(\mathrm{X} \beta) \exp ^{(\mathrm{V}-\mathrm{U})}}{\mathrm{F}(\mathrm{X} \beta)}=\exp ^{(\mathrm{v}-\mathrm{u})}$

The empirical stochastic frontier production model that was used is specified as follows:

In $Y_{1}=\beta_{0}+\beta_{1}$ In $X_{1 i}+\beta_{2}$ In $X_{2 i}+\beta_{3}$ In $X_{3 i}+\beta_{4}$

In $X_{4 i}+\beta_{5}$ In $X_{5 i}+V_{i}-U_{i}$

Where subscripts ij refers to the jth observation of ith farmer

$\mathrm{In}=$ Logarithm to base e,

$\mathrm{Y}=$ value of crops output in aggregate ( $)$

$\mathrm{X}_{1}=$ Farm size (hectares)

$\mathrm{X}_{2}=$ Labour used in crop production (man hours)

$\mathrm{X}_{3}=$ Seeds cost $(\AA)$

$\mathrm{X}_{4}=$ Chemical costs $(\#)$

$\mathrm{X}_{5}=$ Fertilizer $(\mathrm{kg})$

It is assumed that inefficiency effects are independently distributed and Uij arises by truncation (at zero) of the normal distribution with mean $\mathrm{Uij}$ and variance $\delta \mathrm{U}^{2}$ where $\mathrm{Uij}$ 
Specified as; $\mathrm{U}_{\mathrm{i}}=\delta_{0}+\delta_{1}$ In $\mathrm{Z}_{1 \mathrm{i}}+\delta_{2}$ In $\mathrm{Z}_{2 \mathrm{i}}+\delta_{3}$ In

$\mathrm{Z}_{3 \mathrm{i}} \ldots$

\section{Where}

$\mathrm{U}_{\mathrm{i}}=$ technical inefficiency of the ith farmer

$\mathrm{Z}_{\mathrm{i}}=$ Farmer's age (yrs)

$\mathrm{Z}_{2}=$ Years of farming experience of the ith farmer in crop production

$\mathrm{Z}_{3}=$ Amount of credit obtained by the ith farmer (

$\mathrm{Z}_{4}=$ Annual income level ( $)$

$\mathrm{Z}_{5}=$ Years of formal education of the ith farmer $\mathrm{Z}_{6}=$ Gender of the ith farmer measured as dummy (if male 1,0 otherwise)

$\mathrm{Z}_{7}=$ Marital Status of the ith measured as dummy (if married 1, 0 otherwise)

$\mathrm{Z}_{8}=$ Household size of ith farmer (number of people)

$Z_{9}=$ Major occupation of the ith farmer measured as dummy (if major is farming 1, 0 otherwise)

$\mathrm{Z}_{10}=$ Other occupation of the ith farmer measured as dummy (if engaged in any other occupation 1, 0 otherwise)

$\mathrm{Z}_{11}=$ Land ownership status of the ith farmer measured as dummy (if own 1, 0 otherwise) $\mathrm{Z}_{12}=$ Number of crops grown by ith farmer

\section{RESULTS AND DISCUSSION}

The socio-economic characteristics of the respondents are presented in Table 1 . The study revealed that majority of household heads $(94 \%)$ were males. The age of the farmers ranged between 21 and 60 years. Majority of the respondents $(65 \%)$ were between the age of 31 and 50 years. The mean age was 44.3 years. This implies that majority of the farmers were youth; an economic active age that can make positive contribution to agricultural production. Most respondents $(80 \%)$ are married. This contributed widely to the use of family labour by the households as the wives and children constituted the labour force. The literacy level among the farmers in the study area was high. Njoku (1991) observed that formal education has a positive influence on adoption of innovation. In the study area, $49 \%$ of respondents had secondary education. Majority of the respondents (62\%) had more than 11 years of farming experience, and this shows that the managerial ability of the farmers can be inferred to be reasonably good. The study also revealed that a large proportion of the respondents $(67 \%)$ had farm size of 2-4 hectares which were mostly $(70 \%)$ acquired through inheritance. The larger the arm size, the higher the tendency of diversification of crop production thus leading to production for home consumption and for sale (Minot, 1999). The household size of most respondents (88\%) ranged between 1 and 10 members. A large household size also means more mouth to feed, such that for a given farm size large households could produce a smaller market surplus (Minot et al, 2006). However, in traditional agriculture, the larger the household size the more labour force is available for farm activities.

The maximum likelihood Estimates (MLE) of the stochastic production parameters for the crops (in aggregate) are presented in Table 2. The coefficient of farm size and fertilizer are statistically significant. The variance of the farm effect is found to be significant proportion of the total variability of the value of crops production (in aggregate). Gamma $(\gamma)$ is estimated as 0.778 which implies that $77.8 \%$ of the total variation in aggregate crops output is due to technical inefficiency. The parameter Lambda $(\lambda)$ is greater than one. Such a result according to Tadesse and Krishnamoorthy (1997), indicates a good fit for the model. The coefficient of farm size $\left(\mathrm{X}_{1}\right)$ and fertilizer $\left(\mathrm{X}_{5}\right)$ were 0.387 and 0.786 and both were statistically significant. These coefficients denotes the variation or possible change in aggregate output of crops as a result of a unit change in the input

The frequency distributions of efficiency estimates obtained from the stochastic frontier model (Table 3) shows that the $27 \%$ of the farmer operated below efficiency level of $60 \%$. The mean technical efficiency for sample is $69.6 \%$ with minimum of $32.7 \%$. This implies that on the average, farmers were able to obtained $69.6 \%$ potential output from a given combination of production inputs. The implication of the result is such that the average crop farmers requires $34 \%$ i.e. $\{(1-0.696 / 0.894)\} 100$ cost saving to attain the status of the most efficient crop farmer while least performing farmers would need $76 \%$ i.e. $\{(1-0.327 / 0.894)\} 100$ cost saving to become the most efficient farmer. 
Table 1 Socio Economic Characteristics of the Farmers in the Study Area

\begin{tabular}{|c|c|c|}
\hline Characteristics & Frequency & Percentage \\
\hline \multicolumn{3}{|l|}{ Gender } \\
\hline Male & 94 & 94 \\
\hline Female & 6 & 6 \\
\hline Total & 100 & 100 \\
\hline \multicolumn{3}{|l|}{ Ages in years } \\
\hline 21-30 & 11 & 11 \\
\hline $31-40$ & 32 & 32 \\
\hline $41-50$ & 33 & 33 \\
\hline $51-60$ & 20 & 20 \\
\hline Above 60 & 4 & 4 \\
\hline Total & 100 & 100 \\
\hline \multicolumn{3}{|l|}{ Marital Status } \\
\hline Married & 80 & 80 \\
\hline Single & 6 & 6 \\
\hline Divorce & 7 & 7 \\
\hline W idowed & 7 & 7 \\
\hline Total & 100 & 100 \\
\hline \multicolumn{3}{|l|}{ Level of Education } \\
\hline Primary school & 15 & 15 \\
\hline Secondary school & 49 & 49 \\
\hline Tertiary education & 18 & 18 \\
\hline Adult education & $\mathbf{0}$ & $\mathbf{0}$ \\
\hline Quranic education & 4 & 4 \\
\hline No formal education & 14 & 14 \\
\hline Total & 100 & 100 \\
\hline \multicolumn{3}{|l|}{ Household size } \\
\hline $1-5$ & 40 & 40 \\
\hline $6-10$ & 48 & 48 \\
\hline 11-15 & 7 & 7 \\
\hline $16-20$ & 2 & 2 \\
\hline Above 20 & 3 & 3 \\
\hline Total & 100 & 100 \\
\hline \multicolumn{3}{|c|}{ Years of farming experience } \\
\hline $1-10$ & 38 & 38 \\
\hline $11-20$ & 44 & 44 \\
\hline $21-30$ & 14 & 14 \\
\hline 31 and above & 4 & 4 \\
\hline Total & 100 & 100 \\
\hline \multicolumn{3}{|l|}{ Farm size (ha) } \\
\hline$<2$ & 26 & 26 \\
\hline $2-4$ & 67 & 67 \\
\hline $4-6$ & 7 & 7 \\
\hline Total & 100 & 100 \\
\hline \multicolumn{3}{|l|}{ Landownership } \\
\hline Owned land & 70 & 70 \\
\hline Lease land & 30 & 30 \\
\hline Total & 100 & 100 \\
\hline
\end{tabular}

Source: Field survey, 2005: 
The determinants of technical efficiency in crops production in the study Area (Table 4) indicates that farmer's age was positive and significantly related to technical efficiency. The mean age was 44 years. This result however disagree with those of Onyeweaku et al (2004) whose result showed age to be positive and not significant with technical efficiency. Farming experience is negative and not significantly related to technical efficiency. This result disagrees with that of Onyeweaku and Nwaru (2005). Education shows no significant relationship with technical efficiency. This agrees with that of Onyeweaku and Effiong (2005), but disagrees with Onu, et al (2000). Gender is positive and significantly related to technical efficiency. This result tally with that of Ohajianya (2005). The marital status is positive and significantly related to technical efficiency. Amount of credit obtained was positive and showed no significant relationship with technical efficiency. Annual income was positive and show no significant relationship with technical efficiency. Household size was negative and significantly related to technical efficiency. This result disagrees with that of
Onyenweaku and Effiong (2005), but is in consonance with Onyenweaku and Nwaru (2005). Major occupation was negative and not significantly related to technical efficiency. Other occupation was negative and significantly related to technical efficiency. Land ownership was positive and significantly related to technical efficiency. Finally, number of crop grown was positive and not significantly related to technical efficiency. Thus, age, gender, marital status, household size, other occupation and land ownership have significant relationship with efficiency. While farming experience, amount of credit obtained, annual income, educational status, major occupation and number of crops grown are not significantly related to technical efficiency

Table 2 Maximum Likelihood Estimates of the parameter of the Stochastic Frontier Production Function

\begin{tabular}{lllll}
\hline Variable & Parameters & Coefficient & Standard error & T-ratio \\
\hline Constant & $\beta_{0}$ & 0.479 & 0.836 & 0.573 \\
Farm size $\left(\mathrm{X}_{1}\right)$ & $\beta_{1}$ & 0.387 & 0.208 & $1.861^{* *}$ \\
Labour $\left(\mathrm{X}_{2}\right)$ & $\beta_{2}$ & 0.116 & 0.542 & 0.214 \\
Seed $\left(\mathrm{X}_{3}\right)$ & $\beta_{3}$ & 0.278 & 0.228 & 1.219 \\
Chemical $\left(\mathrm{X}_{4}\right)$ & $\beta_{4}$ & 0.277 & 0.430 & 0.644 \\
Fertilizer $\left(\mathrm{X}_{5}\right)$ & $\beta_{5}$ & 0.786 & 0.135 & $5.822^{* * *}$ \\
Sigma-Squared & $\delta^{2}$ & 0.323 & 0.214 & 1.509 \\
Gamma & $\Gamma$ & 0.778 & 0.262 & 2.969 \\
Lambda & $\Lambda$ & 3.504 & & \\
Log likelihood & -0.497 & & & \\
\hline
\end{tabular}

Source: Data Analysis, 2005.

Note:*** Significant at $1 \% * *$ significant at $5 \%$

\section{Table 3. Frequency Distribution of Technical Efficiency Indices}

\begin{tabular}{lll}
\hline Technical Efficiency Range & Frequency & Percentage \\
\hline$\leq 0.40$ & 2 & 2 \\
$0.41-0.60$ & 25 & 25 \\
$0.61-0.80$ & 45 & 45 \\
$0.81-1.00$ & 28 & 28 \\
Total & 100 & 100 \\
\hline
\end{tabular}


Table 4: Determinant of Technical Efficiency in Crop Production

\begin{tabular}{lllll}
\hline Variable & Parameter & Coefficient & Stand error & T-ration \\
\hline Constant & $\mathrm{q}_{0}$ & 57.431 & 3.712 & $15.472^{* *}$ \\
Age $\left(\mathrm{Z}_{1}\right)$ & $\mathrm{q}_{1}$ & 4.479 & 1.645 & $2.723^{* *}$ \\
Farming experience $\left(\mathrm{Z}_{2}\right)$ & $\mathrm{q}_{2}$ & -0.861 & 0.471 & -1.828 \\
Amount of credit obtained $\left(\mathrm{Z}_{3}\right)$ & $\mathrm{q}_{3}$ & 1.010 & 0.611 & 1.653 \\
Annual Income $\left(\mathrm{Z}_{4}\right)$ & $\mathrm{q}_{4}$ & 2.253 & 1.021 & 2.207 \\
Educational status $\left(\mathrm{Z}_{5}\right)$ & $\mathrm{q}_{5}$ & -1.344 & 0.411 & -3.270 \\
Gender $\left(\mathrm{Z}_{6}\right)$ & $\mathrm{q}_{6}$ & 2.352 & 0.466 & $5.047^{* *}$ \\
Marital Status & $\mathrm{q}_{7}$ & 2.337 & 0.594 & $3.934^{* *}$ \\
Household size $\left(\mathrm{Z}_{8}\right)$ & $\mathrm{q}_{8}$ & -2.100 & 0.998 & $-2.104^{* *}$ \\
Major Occupation & $\mathrm{q}_{9}$ & -0.173 & 0.059 & -2.932 \\
Other occupation $\left(\mathrm{Z}_{9}\right)$ & $\mathrm{q}_{10}$ & -10.784 & 1.806 & $3.971^{* *}$ \\
Land ownership $\left(\mathrm{Z}_{11}\right)$ & $\mathrm{q}_{11}$ & 2.704 & 0.796 & $0.877^{* *}$ \\
Number of Crop Grown $\left(\mathrm{Z}_{12}\right)$ & $\mathrm{q}_{12}$ & 1.128 & 1.293 & \\
\hline
\end{tabular}

$* *=5 \%$ significant

NS=Not significant

\section{CONCLUSION}

The results of the study revealed that technical efficiency in crop production in Lafia Local Government Area of Nasarawa State range from $32.7 \%$ to $89.4 \%$ with a mean of $69.6 \%$. This means that there are substantial opportunities to increase productivity and income through more efficient utilization of productive resources. Important factors related to technical efficiency were labour, fertilizer, age, gender, household size, marital status, other occupation and land ownership.

\section{RECOMMENDATION}

The study revealed that farm size and fertilizer are positive significant factors influencing crop production in the Local Government Area. A land redistribution policy that will increase the farm size of farmers since they are mainly small scale farmers will boost crop production. Timely and adequate supply of fertilizer at subsidized rate will enhance the output of crops on farms.

\section{REFERENCES}

Aigner, D. J: Lovell, C.A.K and Schmidt P. (1977). Formulation and estmation of stochastic production function model Journal of Econometrics 6:21-37.

Betesse G. E. and Colli, T. (1995). A model of Technical Inefficiency Effects in a stochastic Friontier Production function for Panel Data. Empirical Economics 20:325-332

Charnes A; Cooper W. W. and Rhodes. E. (1978). Measuring the efficiency of decision making units. European Journal of Operation Research 2429444.
Coelli T; Rao, D.S. and Batese G.E. (1998). An Introduction to efficiency and productivity Analysis Kluver Academic Publishers, Norwell, M. C.

Hang, C.J. and Bagi, F.S. (1984). Technical Efficiency on individual farmers on North West India: Southern Econimic Journal 15(1): 108-115.

Jayaram H.G.S. Chandrashekar L. and Achoth L. (1987). An Economic analysis of technical efficiency in rive cultivation in Mandhya: some Issues in resource priving" Indian Journal of Agricultural Economics 47:657-667.

Junakar, P.N. (1980). Test of the profit maximization hypothesis: A study of Indian Agriculture Journal of Development Studies 16:87-203

Kaliranjan K. (1981). An Economic Analysis of yield variability in Paddy production Canadian Journal of Agricultural Economics 29:283-294

Meusen, N. and Van Den Broeck, J. (1977). Efficiency estimation from Cobb Douglas production function with composite error International Economics Reviews.18(2) 123-134.

Minot, N. Epprecht M, Anh T.T.T. and Trung L.Q (2006). Income diversification in the Northern upland of Vietnarn research 145. International Food Policy Research Institute Washington D.C.

Minot, N. (1999). Effect of transition cost in supply response and market surplus: Simulation using non-separable household model: Discussion paper No 36 Market structure study Division. International Food Policy Research Institute Washington D.C. 
Rahman, S.A. and Umar H.S.

NPC (2006). National Population Commission: Details of the Breakdown of Nasarawa State Provisional 2006 Local Government Census result.

Njoku, J.E. (1991). Factors Influencing the adoption of improve oil palm production technologies by small holders in Imo state, Nigeria In: Olukosi J.O. Ogungbile A.O. and Kalu B.A. (eds) Appropriate Agricultural Technologies for Resource poor framer. A publication of the Nigerian Farming System Research Network p. 25

Okike, I. (2000). Crop/Livestock Interactions and Economic Efficiency of Farmer in the Savannah Zone of Nigeria, Ph.D. Thesis, Department of Agricultural Economics, University of Ibadan 155 pp.

Onu, J.K Amaza P.S and Okunmadewa F.Y. (2000). Determinant of Cotton Production and Economic Efficiency. African Journal of Business and Economic Research 1(2): 24:30.

Onyeweaku, C.E. and Effiong E.O. (2005). Technical Efficiency in pig production in Akwa Ibom State Nigeria International Journal of Agriculture and Rural Development 6:51-58.

Onyeweaku, C.E. and J.C. Nwaru (2005). Application of stochastic frontier production function to the measurement of technical efficiency in food crop production in Imo State, Nigeria The Nigerian Agriculture Journal 36:1-12

Ohajianya D.O. (2005) Economics efficiency among small scale poultry in Imo state; Stochastic Frontier Production Model Approach. International Journal of Agriculture and Rural Developmentl. 6:18:25.
Onyenweaku, C.E. Igwe K.C. and Mbanor J.A. (2004). Application of stochastic frontier production function to the measurement of technical efficiency in yam production on Nasarawa State, Nigeria. Journal of Sustainable Tropical Agricultural Research 13:2025

Parikh, A.F. Ali and M.K. Shah (1995). "Measurement of Economic Efficiency in Pakistani Agriculture" American Journal of Agricultural Economics 77:657-685.

Rahman S.A. Ajayi F.A. and Gabriel J. (2005). "Technical efficiency in Sorghum based cropping systems in Soba Area of Kaduna State Nigeria Journal of Research in Science and Management 3(1): 100-104.

Seyoum E.I. Bathese G.E. and Flemmeng E.M. (1998). Technical efficiency and productivity of Maize production in Eastern Ethiopia Journal of Agricultural Economics 1: 341-348

Shanmugan T.R. and Palanisami K. (1993). Measurement of economic efficiency: Frontier function approach Journal of Indian Society of Agricultural statistics. 45:235-242.

Sharma, K.R. Leung P. and Zaleski H.M. (1999) Technical Allocative and Economic Efficiency in Swine production in Hawaii: A comparison of parametric and non-parametric approaches Journal of Agricultural Economics 20-35

Tadesse, B. and Krishnamoorthy S. (1997) Technical Efficiency of paddy farmers of Tamil Nadu: and analysis based on farm and ecological zone Journal of Agricultural Economics 16:185-192. 
Agro-Science Journal of Tropical Agriculture, Food, Environment and Extension Volume 8 Number 2 Mav 2009 pp $97-103$

ISSN 1119-7455

\title{
ASSESSMENT OF TRAINING NEEDS OF EXTENSION STAFF OF AGRICULTURAL DEVELOPMENT PROGRAMME (ADP), EDO STATE, NIGERIA.
}

\author{
Omoregbee, F.E. and Ajayi, M.T. \\ Department of Agricultural Economics \& Extension Services, Faculty of Agriculture, University \\ of Benin, PMB 1154, Benin-city, Edo State, Nigeria.
}

\begin{abstract}
The study assessed the training needs of extension agents in Edo State Agricultural Development Programme (ESADP). The study specifically examined the socio-economic characteristics of the respondents, tasks and new tasks performed by them and the task areas in which they needed further training. Using structured questionnaire, data were collected from seventy six (76) randomly selected extension agents in 3 agricultural zones of Edo State. Findings revealed that the mean age of the respondents was 41.7 years. More than half (55.3\%) of them holders of National Diploma (ND) and about seventy two percent of the respondents had been working in extension service for 6 and 7 years. The tasks performed by the extension staff ranged from advising farmers on improving methods of farming to new task on health issues such as campaign on HIV/AIDS. The study identified strong training needs for Edo State extension agents on communication skills $(\overrightarrow{X=4.60)})$, planning demonstration $(\bar{X}=4.60)$, evaluation of trials $(\bar{X}=4.57)$ and farmers training $(\bar{X}=4.56)$. The correlation analysis showed that education had significant relationship many areas of the respondents' training needs: farmer identification ( $r=-0.190, p \leq 0.05)$, nutrition and food utilization $(r=0.339, p \leq 0.05)$, communication skills $(r=0.190, p \leq 0.05)$, planning demonstration $(r=0.190, p \leq 0.05)$, recording and reporting $(r=0.260, p \leq 0.05)$, evaluation of trials $(r=0.190, p \leq 0.05)$, and rodents and pest control $(r$ $=0.236, p \leq 0.05$ ). Similarly, job experience had significant relationship with the respondents' training need in the area of planning demonstration $(r=0.190, p \leq 0.05)$. It was suggested that there is a need for regular training needs analysis, especially for new recruited agricultural graduates to determine their areas of deficiencies.
\end{abstract}

Key Words: Assessment, Tasks Performed, Training Needs, Extension Staff, ADP.

\section{INTRODUCTION}

The agricultural development programme (ADP) system in Nigeria was institutionalized in 1974 with funding assistance from the World Bank, Federal and State Governments. Edo State ADP was one of the ADPs established in 1985 as Bendel State ADP o However, in 1991 Bendel ADP was bifurcated into Edo and Delta ADPs upon the state creation exercise of August, 1991. The services of Edo State ADP have been in the areas of agriculture, natural resource and human development.

Extension, as an educational input, can make an important contribution to sustainable agricultural production and rural development.
One of the strategies adopted by Edo State ADP in achieving its set objectives was the dissemination of improved agricultural technologies to the farmers, coupled with education about the technologies. Crowder (1996) reported that there is a critical need for a large number of well trained extension workers in many developing countries. The data collected in a study conducted by FAO Global Consultation on Agricultural Extension (1990) revealed that in the USA, Canada and Europe one extension agent covers about 400 economically active persons in agriculture, even before counting the services provided by the private sector. Higher figure was obtained in four developing regions of Africa, Asia, Latin 
America and the Near East where an extension worker covers on average about 2,500 active persons in agriculture.

Today, educational programmes delivered by extension agents in Edo ADP are more varied than ever and will continue to change to meet the needs of the clientele they serve. Radhakvishna and Thomson (1996) further stated that extension agents particularly require experiential learning that provides them with opportunities to relate to rural people in an interactive process that combines scientific technical knowledge with local indigenous knowledge in client-centered problem solving activities.

To satisfy this requirement, there is a need to regularly analyze the technical competence and job performance of extension staff in the organization. Yondeowei and Kwarteng (2006) defined training need as the difference between the required level of individual competence and his present level of competence. Allo (2001) pointed out that one of the main factors limiting the development of effective training programmes for agricultural professionals in developing countries is the inadequacy of information on their training needs. In this regard, there is also the need to rationalize training to minimize repetition of the same message, more exposure to relevant technology and communication techniques, more avenues for personal career development and frequent contact between various categories of extension personnel.

This study is therefore undertaken to assess the training needs of extension staff in Edo State ADP. Specifically, the study aimed to:

- examine the socio-economic characteristics of extension staff of the Edo State ADP;

- $\quad$ identify the new tasks being performed by extension staff of the Edo State ADP;

- $\quad$ determine the task areas in which extension agents needed further training.

Hypothesis of the study

$\mathrm{H}_{0} \quad$ There is no significant relationship between the Edo State ADP Extension workers' socio-economic characteristics and their training needs

\section{RESEARCH METHODOLOGY}

This study was conducted in Edo State Agricultural Development programme (ESADP), Nigeria. Edo State covers a total area of about
17,802 square kilometers with 180,000 farm families. For effective extension coverage, ESADP is divided into three agricultural zones as follows: Edo Central, Edo North and Edo South zone. The Edo central is divided into five blocks as follows: Esan Central, Esan West, Esan North-East, Esan South-East and Igueben Local Government Areas (LGAs). The Edo North Comprises 6 blocks, namely: Owan West, Akoko-Edo, Etsako West, Etsako East, Owan East and Etsako Central LGAs. The Edo South consists of seven (7) blocks namely, Oredo, Ovia south West, Ovia North East, Ikpoba-Okha, Egor, Uhunmwode and Orhionwon LGAs. In all, there are total of 18 blocks or LGAs in the study area. At the time this study was being conducted, there were 80 extension staff in ESADP which was distributed as follows: Edo Central (13), Edo North (28) and Edo South (39). Due to the few numbers of extension staff in Edo State, a proportional sample of $95 \%$ from each zone was randomly selected to have a total of 76 respondents for the study. For the purpose of this study a structured questionnaire was the instrument used for data collection. The training needs of extension staff as conceived in this study implies the assessment of the skills, knowledge and attitudes that are desirable for the extension staff as well as determining how much the present condition departs from those conditions which are optimal for meeting these needs.

Measurement of Variables. Training Needs: The process of analysis of training needs of an organization as stated by Mc Gee and Paul (1961) comprised a three fold approach, namely: organizational, job or occupational and man analysis. This study adopted the job or occupational analysis. It entails identifying tasks performed by the organizational staff and identifying the tasks in which staff require for further re-training to perform them well. Seventeen (17) of such tasks were identified in this study and the respondents were asked to indicate the tasks they perform in which they require re-training. Demographic profile of respondents: A selected personal characteristics of respondents namely age; gender, educational status and job experience were measured. Age was measured in years, gender as male or female, educational status as the highest certificate obtained and job experience as the number of years spent on the job.

Data were analysed using descriptive statistics such as frequency counts, percentages, means and standard deviation. Correlation 
analysis was used to test the hypothesis of the study. Some of the variables were measured using a Likert-type-scale. For example, a 5- point likert- scale ranging from "strongly agree" (5). " agree" (4), "Undecided" (3), "disagree" (2), to "strongly disagree" (1) was used to assess respondents perception of the extension agents training needs. A mean score of 3.50 and above indicates areas of training needs while a mean score lower than 3.50 indicates areas where training are not needed.

\section{RESULTS AND DISCUSSION \\ Personal characteristics of respondents:}

The personal characteristics of the respondents are presented in Table1. More than half $(59.2 \%)$ of the respondents were in the age group of between 40 and 49 years and the remaining $43.8 \%$ of them belonged to different age groups of 20-29 years (4.0\%), 30-39 years $(26.3 \%)$ and 50 years and above $(10.5 \%)$ respectively. This implies that most $(89.5 \%)$ of the extension staff in Edo State ADP is still young. This means that skills acquired through re-training and training programmes can still be utilized in the organization for at least 16years.

As shown in Table1, 57.9\% of the respondents were males while $42.1 \%$ were females. In the past, extension job was reserved for men only believing that it was only men that were farmers and that men needed to reach them (Airemen, 2005). However presently, accepting the fact that women are also farmers and need to be reached in order to achieve increased productivity has necessitated the employment of female extension workers who are believed to be in a better position to do the job of reaching women.

More than half of the respondents were OND holders $(55.3 \%)$. This was followed by HND $(27.6 \%)$, NCE (15.8\%) graduates and a few B.Sc. degree holders (1.3\%). It is generally assumed in Nigeria that extension job is a lowstatus job fit only for job applicants possessing low academic qualifications (Ejembi et al,.2006). Results of this study do not contradict this view Oladoja (2004) indicated that the process of technology transfer should not focus only on the transfer of innovations but also on the transfer of scientific and managerial skills. Agricultural extension staff needs to be trained and retrained to respond well to their functions of communicating and assisting farmers to make decisions on new technologies.

Most $(72.3 \%)$ of the respondents had working experience as extension staff for between 6 and 7 years. Some of them had put in 4-5 years while very few of them had been in the service for 2-3years. The length of service is probably an indicator of a person's commitment to the chosen career (Ejembi et al.2006). Frequent training and re-training programmes are needed to be put in place by an organization to strengthen this commitment. 
Training Needs of Extension Staff of Edo State ADP.

Table 1: Personal characteristics of respondents $(n=76)$

\begin{tabular}{lcc} 
Socio-economic variables & Frequency & Percentage $(\%)$ \\
\hline Gender & & 57.9 \\
Male & 44 & 42.1 \\
Female & 32 & 4.0 \\
Age & 3 & 26.3 \\
20-29 years & 20 & 59.2 \\
30-39 years & 45 & 10.5 \\
40-49 years & 8 & 15.8 \\
50 years and Above & & 55.3 \\
Educational level & 12 & 27.6 \\
NCE & 42 & 1.3 \\
OND & 21 & 6.6 \\
HND & 1 & 13.2 \\
B.Sc. & & 72.3 \\
Job experience & 5 & 7.9 \\
2-3 years & 10 & \\
4-5 years & 55 & \\
6-7 years & 6 & \\
Above 7 years & &
\end{tabular}

Source: Field survey data, 2007.

Table2: Percentage distribution of the respondents on the basis of the tasks being performed by them $(n=76)$.

\begin{tabular}{lll} 
Task s performed & $(\text { No })^{*}$ & $(\%)^{*}$ \\
Establishment of SPAT & 47 & 58.8 \\
Farm visit & 47 & 58.8 \\
Market survey & 35 & 43.8 \\
Provision of farm inputs & 32 & 40.0 \\
Record keeping & 32 & 40.0 \\
Group formation & 29 & 36.3 \\
Linkage to credit facilities & 24 & 30.0 \\
Formation of co-operative groups & 17 & 21.3 \\
Demonstration of improved technologies & 15 & 18.8 \\
Selection of contact farmers & 12 & 15.0 \\
-Formation of women groups & 9 & 11.3 \\
Assist the subject matter specialist & 7 & 8.8 \\
Rendering of technical advise to farmers & 6 & 7.5 \\
Establishment of school programme & 4 & 5.0 \\
Food utilization demonstration & 4 & 5.0 \\
Agro-chemical skill training & 1 & 1.3 \\
Campaign on HIV/AIDS & 1 & 1.3 \\
\hline
\end{tabular}

- Multiple responses Source: Field survey data, 2007.

\section{Tasks Performed by Respondents:}

Data in Table2 reveal the various tasks performed by the ESADP's extension agents. The major tasks performed by the respondents were the establishment of small plot adoption technique (SPAT) (58.8\%), Farm visit (58.8\%), Market survey (43.8\%), provision of farm inputs $(40 \%)$ and record keeping (40\%). The least performed tasks by the respondents were agrochemical skill training $(1.3 \%)$ and campaign on HIV/AIDS (1.3\%). The various tasks performed by the extension staff in agriculture in Table2 portray the fact that agricultural extension involves a great deal more than simply walking into a farm and telling a farmer about a new technology. Allo (2001) asserted that extension is a highly sophisticated technique which demands a considerable range of skills. For extension staff to acquire this sophisticated technique Allo (2001) suggested that in designing a course for extension workers, the following allocation of time should be implemented. These are motivation-20\% of the total time, extension- $20 \%$ of the total time, technology- $40 \%$ of the total time and practical work-20\% of the total time. The inclusion of campaign on HIV/AIDS to the tasks performed by the extension staff showed that they carry out functions beyond their traditional task of offering pieces of advice, helping farmers analyze problems and identifying opportunities, sharing information, supporting group formation and facilitating collective action. They have also included provision of information on health problems to farmers 
Omoregbee, F.E. and Ajayi, M.T.

\section{Respondents' areas of training needs:}

Entries in Table3 indicate that the respondents needed training in the following areas: communication skill $(\bar{X}=4.60)$, planning demonstration ( $\mathrm{X}=4.60)$, Evaluation of trials $\overline{\mathrm{X}}$ =4.57), farmers $(\mathrm{X}=4.52)$, rodents and pest control $\overline{(X}=4.48)$, recording and reporting $\overline{(X}=4.46)$, establishment of SPAT $(\bar{X}=4.46)$, formation of women groups $(\overline{\mathrm{X}}-4.35)$, nutrition and food utilization demonstration $(\bar{X}=4.24)$ and farmer identification $(\bar{X}=4.18)$. These findings indicate that the areas in which respondents expressed training needs are very relevant to knowledge and skills required for executing extension programmes as well as responding to farmers' needs. This is in line with the view of Androulitakis and Siardos (2005) that extension agents' competence should be in accordance with the task areas in which they will be assigned to operate in order to perform successfully. Hence, the importance of in-service training.

The deficiency in extension methodology observed in Table 3 could be as a result of inadequate pre-service training of the respondents. According to Van Crowder (1996), extension methodology is often by-passed in many intermediate levels whose primary function is to train students to work as field extension agents in an effort to insert specialized technical agriculture in the curriculum.

Table 3: Respondents' perception of areas of training needs $(n=76)$.

\begin{tabular}{lll} 
Areas of training needs & Mean & Standard deviation \\
\hline Communication skill & 4.60 & 0.49 \\
Planning demonstration & 4.60 & 0.49 \\
Evaluation of trials & 4.57 & 0.50 \\
Farmers training & 4.56 & 0.50 \\
Selection of contact farmers & 4.52 & 0.75 \\
Rodents and pest control & 4.48 & 0.50 \\
Recording and reporting & 4.46 & 0.75 \\
Establishment of SPAT & 4.46 & 0.84 \\
Formation of women groups & 4.35 & 0.48 \\
Nutrition and food utilization demonstration & 4.24 & 0.43 \\
Farmer identification & 4.18 & 0.92 \\
\hline
\end{tabular}

Likert scale: 5 = strongly agree, 4 = Agree, 3 = Undecided, 2 = Disagree, 1 = Strongly disagree.Training is needed whenX $>3.50$ Source: Field survey data, 2007

Table 4: Relationship between some selected respondents' personal characteristics and their training needs.

\begin{tabular}{llll} 
Training needs & Age & Education & Job experience \\
\hline Farmer identification & -0.16 & $-0.190^{*}$ & 0.034 \\
Selection of contact farmers & 0.111 & -0.011 & 0.025 \\
Nutritional and food utilization & -0.148 & $0.339^{*}$ & 0.053 \\
Demonstration & & & \\
Establishment of SPAT & 0.019 & 0.110 & 0.018 \\
Communication skills & 0.139 & $0.190^{*}$ & 0.074 \\
Farmers training & 0.046 & 0.035 & 0.090 \\
Formation of women groups & 0.050 & 0.066 & 0.080 \\
Planning demonstration & -0.107 & $0.190^{*}$ & $0.190^{*}$ \\
Recording and reporting & -0.139 & $0.260^{*}$ & 0.040 \\
Evaluation of trials & 0.031 & $0.190^{*}$ & 0.123 \\
Rodents and pest control & -0.117 & $0.236^{*}$ & -0.090 \\
\hline
\end{tabular}

- $\quad$ Significant at $\mathrm{p} \leq \mathbf{0 . 0 5}$

Source: Field survey data, 2007. 


\section{Relationship between respondents' personal characteristics and their training needs:}

Table 4 shows the relationship between respondents' personal characteristics and their training needs. The table shows that education had significant relationship with many areas of respondents' training needs: : farmer identification $(\mathrm{r}=-0.190, \mathrm{p} \leq 0.05)$, nutrition and food utilization $(\mathrm{r}=0.339, \mathrm{p} \leq$ $0.05)$, communication skills $(\mathrm{r}=0.190, \mathrm{p} \leq$ $0.05)$, planning demonstration $(\mathrm{r}=0.190, \mathrm{p} \leq$ $0.05)$, recording and reporting $(\mathrm{r}=0.260, \mathrm{p} \leq$ $0.05)$, evaluation of trials $(r=0.190, p \leq 0.05)$, and rodents and pest control $(\mathrm{r}=0.236, \mathrm{p} \leq$ 0.05 ). This result is not unexpected because technical skills are easily acquired through education. Similarly, job experience had significant relationship with the respondents' training need in the area of planning demonstration $(\mathrm{r}=0.190, \mathrm{p} \leq 0.05)$. However, age of respondents was not significantly related to the training needs of respondents. It is possible that age may not be a significant factor in determining training needs. Old or young people can be re-trained to enhance their competence on the job.

\section{CONCLUSION AND RECOMMENDATIONS}

This study established that there were more males' extension agents in ESADP than females. The study also established that majority of the ESADP's extension agents were either OND or HND holders with majority having 6-7 years of working experience. The study also established that ESADP's extension agents performed other task other than their traditional tasks. It was also established that many extension agents were deficient in the important subject matter areas that are necessary for extension agents to perform effectively such as communication skills, planning demonstration, evaluation of trials, farmers training and selection of contact farmers. The implication of these findings is that most of these subject areas are likely to be lacking in the pre-service training curriculum of the agricultural graduates recruited as extension agents in ADPs.

Based on the findings and conclusion reached in this study the following recommendations were made:

Training needs analysis should be carried out for new recruit graduates and also periodically to determine the training needs of extension agents.

- $\quad$ In-service training should be planned for extension agents in social science skills that are mostly deficient in agricultural graduates such as communication skills, evaluation and research methods.

There is a need for collaboration between ADPs and agricultural institutions in reviewing agricultural extension curriculum in agricultural institutions that will assist the agricultural extension graduates in facing new challenges so as to perform effectively and efficiently as extension agents.

\section{REFERENCES.}

Airemen, S.A. (2005). Training needs of extension staff in agriculture: A case study of EdoState agricultural development programme. Unpublished B.Sc thesis. Department of agricultural economics and extension, Faculty of Agriculture, University of Benin, Benin-City. pp 10-18.

Allo, A.V. (2001). Professional requirements of the extension worker in training the extension worker. FFTC extension bulletin No. 173 .

Androuhdkis, S.I. and G.C. Siardos (2005).Agricultural extension agents' perception regarding their relevance and competence in certain professional task areas. Jimmyproject materials II. 4p. Available at www.jimmy project.org.

Crowder, L.V. (1996). Assessment of preservice and in-service extension education. Agricultural extension and education service (SDRE). FAO Research, extension and training division. 3p. Also availabl atwww.fao.org/sd/exdirect/exan 001.htm.

Ejembi, E.P; F.E.Omoregbee and S.A.Ejembi (2006). "Farmers' assessment of the training and visit extension system in central Nigeria: Evidence from Barkin Ladi,Plateau State". Journal of Social Sciences. 12 (3):207-212.

Food and Agriculture Organization (FAO) (1990). Global consultation on agricultural extension.

McGee, W and T. Paul (1961). Training in business and industry. Wiley publishers. New York. USA. pp 3036.

Oladoja, A.M. (2004).Analysis of the training needs of extension agents in Lagos State ADP.Unpublished B.Sc. Thesis. Department of Agricultural Extension and RuralDevelopment. Faculty of Agriculture, University of Ibadan.pp 50-53. 
Radhakrishna, R.B and J.S. Thomson (1996).'Extension agents' use of information sources. Journal of Extension. 34(1):12-17.
Youdeowei,A and Kwarteng, J. (2006). Tool Kit for the production of agricultural extension materials. Guide book. CTA Wageningen, The Netherlands.50pp. 
Agro-Science Journal of Tropical Agriculture, Food, Environment and Extension Volume 8 Number 2 May 2009 pp 104-109

ISSN1119-7455

\title{
EVALUATION OF NEW GENERATIONS OF MAIZE STREAK VIRUS (MSV) RESISTANT VARIETIES FOR GRAIN YIELD, AGRONOMIC POTENTIAL AND ADAPTATION TO A SOUTHERN GUINEA SAVANNA ECOLOGY OF NIGERIA
}

\author{
Olaoye G. \\ Department of Agronomy University of Ilorin \\ P.M.B. 1515, Ilorin, Nigeria.
}

\begin{abstract}
Five new generations of maize streak virus (MSV) resistant varieties were evaluated along with two checks in replicated trials and for two years in a southern guinea savanna ecology of Nigeria, which is an endemic zone for the disease. Difference in grain yield between favourable growing season in 2002 and unfavourable season in 2001 was $1.68 \mathrm{t}^{-\mathrm{ha}^{-1}}$, representing $30.2 \%$ yield increase of 2001 performance. Results further showed that while both rust and streak diseases appeared to have been put in check, the genotypes showed slight susceptibility to leaf blight and curvularia leaf spot, ranging from 5-7 and 4-8 percent (\%) respectively. Genotypic differences were significant for grain yield, agronomic traits as well as incidences of leaf blight and curvularia leaf spot. Acr 91 Suwan-1$S R C_{1}$ was the most productive of new generations of MSV resistant varieties, having yielded significantly higher than OPV check by 32 percent (\%) and comparable with the hybrid check for grain yield. The variety could therefore serve as replacement to existing cultivar and also as source of genes for future maize breeding activities in the development of superior maize varieties for the southern guinea savanna ecology.
\end{abstract}

Key words: Genotypes, grain yield, leaf diseases, adaptation. e-mail: debolaoye @ yahoo.com

\section{INTRODUCTION}

Maize (Zea mays L.) production in tropical Africa is constrained by a number of stress factors including a complex of insect and disease organisms that significantly reduce the quantity and quality of production (Fajemisin et al., 1984; Fajemisin, 1985, Fajemisin et al., 1985; Mihm, 1994). In Nigeria, maize streak virus (MSV) disease which is transmitted by the aphids (Cicadulina species), reduces maize grain yield particularly during the late cropping season once there is a prolong drought spell. The disease reached epiphytotic level in Nigeria in the 1970's, causing significant yield loss in endemic zones (Fajemisin, 1984). Although collaborative research efforts by maize scientists at both international centres and national agricultural research systems has succeeded in converting established varieties and breeding populations from different sources to streak resistant (Fakorede et al., 2001), newly developed varieties meant for cultivation in endemic zones, normally have genes for streak resistance incorporated into them at one stage of development or the other. One of the major constraints in varietal development is the evolution of a virulent strain to which previously resistant varieties may be susceptible (Fakorede et al., 2001). For example, survey of leaf diseases in the south western Nigeria showed that occurrence of other maize leaf diseases such as maize leaf rust (Pucinia polysora); maize leaf spots (Curvularia lunata) and maize ear rot (Fusarium moniliforme) are on the increase (Olakojo and Iken, 1999).Therefore, newly developed maize varieties are routinely evaluated in various agro-ecological zones for adaptation, yield potential and disease reactions, to identify genotypes that can replace existing cultivars and as part of the requirements for releasing suitable varieties for cultivation in farmers' fields (Olakojo and Iken, 2001). Furthermore, since every agroecology has unique growing conditions, it is important to assess newly developed varieties for yield potentials as well as reaction to other stress factors that may be unique to the environment before being recommended for cultivation. In the study reported herein, five (5) recently developed MSV resistant OPVs were evaluated along with an earlier version 
(DMR-LSR-Y) and one hybrid (Oba Super 2) as checks for two years at Ilorin, a typical southern guinea savanna ecology of Nigeria. The objective was to determine their yield and agronomic potentials with the view to recommending suitable varieties either for direct cultivation in this ecology or as replacement to the existing variety

\section{MATERIALS AND METHODS}

The field trials were conducted at the University of Ilorin Teaching and Research (T\&R) farm (Lat. 8 $29^{\prime} \mathrm{N} \& 8^{\circ} 30^{\prime} \mathrm{N}$; Long. $4^{\circ}$ $\left.30^{\prime} \mathrm{E} \& 4^{\circ} 32^{\prime} \mathrm{E}\right)$ during the late growing seasons of 2001 and 2002 respectively. Plantings were carried out during the month of July which is the common planting period for late maize in this ecology. The soil has been characterized as an alfisol and rainfall distribution is bimodal with peaks at May/June and September respectively. The experiment was set up each year as a randomized complete block design (RCBD) with four replications. The plot size consisted of four rows, $5 \mathrm{~m}$ long with inter and intra row spacing of $0.75 \mathrm{~m} \mathrm{x}$ $0.5 \mathrm{~m}$. The characteristics of the genetic materials are presented in Table 1. Three seeds were planted/hill but later thinned to two/hill to give a plant population of approximately 53,333 plans/ha. Crop management practices included weed control with pre-emergence application of herbicide (Attrazine of $80 \%$ wettable powder). The herbicide was applied at the rate of $100 \mathrm{ml}$ to 20 liters of water and was supplemented each year by one hoe weeding. Fertilizer application was carried out as splitdosage at the rate of $80 \mathrm{kgN} / \mathrm{ha}, 60 \mathrm{~K}_{2} \mathrm{O} / \mathrm{ha}$ and $60 \mathrm{P}_{2} \mathrm{O}_{5}$ at three weeks after planting (3WAP) and at anthesis (7WAP), using compound fertilizer (NPK 20:10:10). Just before flowering, all plants from the two middle rows in a plot were counted and assessed for occurrence of foliar diseases (rust, blight, curvularia leaf spot and streak). Only plants with obvious infection signs covering more than $50 \%$ of the leaf surfaces were counted and expressed as a percentage of total stand count in a plot. Data were also collected from the two middle rows from each plot on days to mid-flowering (tasseling, anthesis and silking), plant and ear heights, ear aspect, ear number (ENO) and grain yield. Anthesis-silkinginterval (ASI) was estimated as the interval in days between mid-anthesis and silking. Grain yield was first obtained as kilogram/plot before being converted into tons/ha after adjusting to $12 \%$ moisture content. At harvest, plants from the two middle rows were also rated on a scale of 1 (Excellent) to 5 (Very poor) for husk cover, plant and ear aspects and lodging characteristics (stalk \& root). The experiment was repeated in the 2002 late cropping season and the same data as for 2001 were also collected. Data collected were subjected to analyses of variance (ANOVA) first on individual year basis before a combined ANOVA over years. Due to very low incidence of both rust and streak in the two transformed using arcsine transformation (Snedecor and Cochran, 1967). However, since ANOVA did not detect any significant difference between transformed and untransformed values, untransformed values are hereby presented for the two characters. Pertinent means were thereafter separated by use of the least significant difference (LSD) according to Steel and Torrie (1980). years of evaluation, the two parameters were dropped from the analyses. Data on blight and curvularia leaf spot were first.

\section{RESULTS}

The two years differed significantly $(P=0.05)$ for days to anthesis and stalk lodging but neither for other agronomic parameters nor leaf disease incidence (Table 2). Rainfall amount and distribution during the growing periods of both years (Fig. 1) also showed that 2001 and 2002 rainfall was evenly distributed throughout the flowering/grain filling periods of September and October, 2002 while in 2001 , there was early on set of terminal drought.

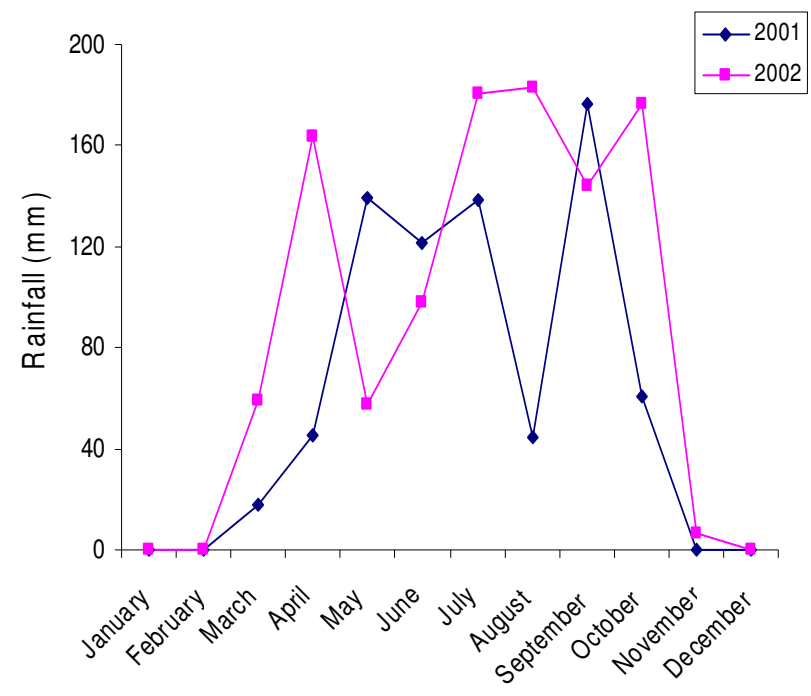

Figure 1. Rainfall distribution for llorin for 2001 and 2002 
Olaoye G.

The genotypes attained anthesis earlier in 2001 than in 2002 by two (2) days but with corresponding higher stalk and root lodging ratings. However, ASI and plant aspect remained relatively unaffected by differences in growing conditions between the two years. Although incidence of leaf diseases (Blight and Curvularia) were higher in 2002, differences between the two years were non significant for these parameters. Grain yield and related traits except ear placement and husk cover differed significantly (P 0.05 $\leq 0.01$ ) between the two years (Table 3). In consonance with higher ENO, grain yield was significantly higher in 2002 by $1.68 \mathrm{t}^{\mathrm{h}} \mathrm{ha}^{-1}$, compared to 2001, representing $30.2 \%$ yield increase. However, this increase was accompanied by higher grain moisture content and lower rating for ear aspect in the genotypes. Although ear placement was higher in 2002 cropping season, difference between years for this trait was not significant.

Differences among genotypes were significant for days to anthesis, lodging characteristics and disease incidence ratings but not for ASI and plant aspect (Table 2). The new generations of MSV resistant genotypes except Acr 91 Suwan-1-SR C1 attained

Table 1: Pedigree and grain characteristics of the Experimental Materials.

\begin{tabular}{lllll}
\hline S/N & Variety & Parent Population & Origin & Grain Type \\
\hline 1. & AK-9528-DMRSR & Pop 28 SR & IITA/CIMMYT & Flint/Dent \\
2. & IK.91 TZL Comp 3-Y C C & TZL Comp 3 & IITA & Flint/Dent \\
3. & Acr. 91 Suwan-1-Sr C & Suwan-1 & Thailand/IITA & Flint \\
4. & TZB-SR SGY & TZB-SR & Nigeria/IITA & Flint/Dent \\
5. & Ikenne 88 TZSR-Y-1 & TZSR-Y-1 & IITA & Flint/Dent \\
6. & Oba Super 2 & Hybrid Check & IITA/Pioneer & Flint \\
7. & DMR-LSR-Y & OPV Check & IITA & Flint/Dent \\
\hline
\end{tabular}

OPV; Open Pollinated variety.

Table 2: Effects of years on flowering traits, lodging characteristics and disease rating (\%) in seven MSV resistant genotypes (Ilorin, Nigeria).

\begin{tabular}{|c|c|c|c|c|c|c|c|}
\hline \multirow[b]{2}{*}{ Year } & \multicolumn{2}{|c|}{ Flowering characteristics } & \multirow[b]{2}{*}{ Plant aspect } & \multicolumn{2}{|c|}{ Lodging characteristics } & \multicolumn{2}{|c|}{ Leaf disease rating $(\%)$} \\
\hline & Days to Anthesis (no) & ASI (no) & & Stalk lodging & Root lodging & Blight & Curvularia leaf spot \\
\hline 2001 & 64 & 2.8 & 2.45 & 2.46 & 1.96 & 6.39 & 5.91 \\
\hline 2002 & 66 & 3.1 & 2.43 & 2.36 & 1.86 & 6.73 & 5.58 \\
\hline $\mathrm{LSD} \propto 0.05$ & 0.75 & Ns & Ns & 0.08 & Ns & ns & Ns \\
\hline
\end{tabular}

$*, * *$; significant at 0.05 and 0.01 levels of probability, respectively.

Table 3: Genotypic means for flowering traits, lodging characteristics and disease rating (\%) in seven MSV resistant genotypes (Ilorin, Nigeria).

\begin{tabular}{|c|c|c|c|c|c|c|c|}
\hline & \multicolumn{3}{|c|}{ Flowering characteristics } & \multicolumn{2}{|c|}{ Lodging characteristics } & \multicolumn{2}{|c|}{ Leaf disease rating $(\%)$} \\
\hline Genotype & Days to Anthesis & ASI & Plant aspect & Stalk lodging & Root lodging & Blight & Curvularia leaf spot \\
\hline AK-9528-DMRSR & 66 & 2.3 & 2.38 & 2.36 & 1.50 & 7.07 & 6.49 \\
\hline IK.91 TZL Comp 3-Y C1 & 65 & 2.6 & 2.38 & 2.13 & 2.00 & 6.44 & 4.55 \\
\hline Acr. 91 Suwan-1-Sr C1 & 64 & 3.0 & 2.63 & 2.00 & 2.25 & 7.14 & 5.24 \\
\hline TZB-SR SGY & 66 & 2.9 & 2.38 & 2.50 & 1.75 & 5.85 & 5.14 \\
\hline Ikenne 88 TZSR-Y-1 & 65 & 3.0 & 2.50 & 2.75 & 1.75 & 5.07 & 5.36 \\
\hline Oba Super $2+$ & 64 & 3.5 & 2.25 & 2.38 & 1.88 & 5.64 & 5.44 \\
\hline DMR-LSR-Y++ & 64 & 3.1 & 2.63 & 2.75 & 2.38 & 8.70 & 8.01 \\
\hline $\mathrm{LSD} \propto 0.05$ & 1.70 & ns & Ns & 0.57 & 0.53 & 1.58 & 1.35 \\
\hline \multicolumn{8}{|l|}{ F-test } \\
\hline Year (Y) & $60.07 *$ & 0.88 & 3.45 & $10.45^{*}$ & 50.16 & 4.57 & 2.16 \\
\hline Genotype (G) & $4.61 *$ & 1.24 & 4.46 & $8.46^{*}$ & $7.91 *$ & $227.83 * *$ & $5.19 * *$ \\
\hline$Y \times G$ & 3.41 & 1.08 & 2.43 & 4.89 & 2.79 & 137.66 & 1.08 \\
\hline$\% \mathrm{CV}$ & 1.91 & 1.13 & 14.65 & 10.56 & 12.56 & 18.05 & 17.45 \\
\hline
\end{tabular}

$*, * * ;$ significant at 0.05 and 0.01 levels of probability respectively.

,+++ ; Hybrid and Open pollinated variety (OPV) checks respectively. 
Evaluation for Maize Streak Virus Resistant Varieties

Table 4: Effects of years on grain yield and related traits in seven MSV resistant genotypes (Ilorin, Nigeria).

\begin{tabular}{llllllll}
\hline Year & $\begin{array}{l}\text { Grain yield } \\
(\mathrm{t} / \mathrm{ha})\end{array}$ & Ear number & $\begin{array}{l}\text { Ear } \\
(\mathrm{cm})\end{array}$ & height & Husk cover & Ear aspect & $\begin{array}{l}\text { Harvest moisture } \\
(\%)\end{array}$ \\
\hline 2001 & 3.89 & 33 & 63.4 & 2.25 & 2.46 & 11.15 \\
2002 & 5.57 & 36 & 66.1 & 2.11 & 3.39 & 14.21 \\
LSD $\alpha 0.05$ & 0.38 & 1.09 & Ns & Ns & 0.14 & 0.34 \\
\hline
\end{tabular}

*, **; significant at 0.05 and 0.01 levels of probability respectively.

Table 5: Genotypic means for grain yield and related traits in seven MSV resistant genotypes (Ilorin, Nigeria).

\begin{tabular}{|c|c|c|c|c|c|c|c|c|c|}
\hline & $\begin{array}{l}\text { Grain } \\
\text { yield } \\
\left(\mathrm{t} / \mathrm{ha}^{-1}\right)\end{array}$ & $\begin{array}{l}\text { Ear } \\
\text { number }\end{array}$ & Ear height $(\mathrm{cm})$ & $\begin{array}{l}\text { Husk } \\
\text { cover }\end{array}$ & Ear aspect & $\begin{array}{l}\text { Harvest } \\
\text { moist } \\
\text { ure }(\%)\end{array}$ & $\begin{array}{l}\text { Ranking } \\
\text { based } \\
\text { on grain } \\
\text { yield }\end{array}$ & \multicolumn{2}{|c|}{$\begin{array}{l}\% \text { yield advantage } \\
\text { or loss over } \\
\text { best check }\end{array}$} \\
\hline Genotypes & & & & & & & & Hybrid & OPV \\
\hline AK-9528-DMRSR & 4.59 & 33 & 62.3 & 2.38 & 3.00 & 12.50 & $6^{\text {th }}$ & -12.90 & 28.94 \\
\hline IK.91 TZL Comp 3-Y C1 & 4.61 & 36 & 69.6 & 2.38 & 3.00 & 12.83 & $5^{\text {th }}$ & -12.52 & 29.49 \\
\hline Acr. 91 Suwan-1-Sr C1 & 5.25 & 36 & 61.1 & 2.25 & 3.00 & 12.54 & $2^{\text {nd }}$ & -0.38 & 47.47 \\
\hline TZB-SR SGY & 4.63 & 37 & 59.3 & 1.88 & 3.00 & 12.80 & $4^{\text {th }}$ & -12.14 & 30.06 \\
\hline Ikenne 88 TZSR-Y-1 & 4.91 & 34 & 66.9 & 1.63 & 3.00 & 12.85 & $3^{\text {rd }}$ & -6.83 & 37.92 \\
\hline Oba Super 2+ & 5.27 & 33 & 66.5 & 2.75 & 2.5 & 12.25 & $1^{\text {st }}$ & & \\
\hline DMR-LSR-Y++ & 3.56 & 31 & 67.7 & 2.00 & 3.00 & 13.01 & $7^{\text {th }}$ & & \\
\hline Genotype Mean & 4.73 & 34.32 & 64.8 & 2.18 & 2.93 & 12.68 & & & \\
\hline $\mathrm{LSD} \propto 0.05$ & 0.83 & 3.56 & Ns & 0.53 & Ns & Ns & & & \\
\hline F-test & & & & & & & & & \\
\hline Year (Y) & $91.55 * *$ & $138.24^{*}$ & 105.88 & 2.16 & $12.07 * *$ & $25.25 * *$ & & & \\
\hline Genotype (G) & $2.26^{*}$ & $43.87 * *$ & 119.98 & $4.58 * *$ & 0.29 & 0.39 & & & \\
\hline$Y \times G$ & 1.34 & $35.20 *$ & 116.58 & 1.45 & 0.41 & 0.80 & & & \\
\hline$\% \mathrm{CV}$ & 17.56 & 7.23 & 11.79 & 18.56 & 15.63 & 7.22 & & & \\
\hline
\end{tabular}

*, **; significant at 0.05 and 0.01 levels of probability respectively.

,+++ ; Hybrid and Open pollinated variety (OPV) checks respectively.

Table 6: Interactive effects of genotype $x$ year for number of ears per plot and grain yield in seven MSV resistant varieties (Ilorin, Nigeria).

\begin{tabular}{|c|c|c|c|c|}
\hline \multirow[b]{3}{*}{ Genotype } & \multicolumn{2}{|c|}{ Ear number } & \multicolumn{2}{|c|}{ Grain Yield $\left(\mathrm{t} / \mathrm{ha}^{-1}\right)$} \\
\hline & \multicolumn{2}{|c|}{ Year } & \multicolumn{2}{|c|}{ Year } \\
\hline & 2001 & 2002 & 2001 & 2002 \\
\hline AK-9528-DMRSR & 29 & 36 & 3.49 & 5.70 \\
\hline IK.91 TZL Comp 3-Y C1 & 36 & 37 & 3.80 & 5.42 \\
\hline Acr. 91 Suwan-1-Sr C1 & 35 & 38 & 4.41 & 6.10 \\
\hline TZB-SR SGY & 39 & 35 & 4.06 & 5.20 \\
\hline Ikenne 88 TZSR-Y-1 & 33 & 35 & 4.56 & 5.26 \\
\hline Oba Super 2+ & 31 & 36 & 4.25 & 6.29 \\
\hline DMR-LSR-Y++ & 26 & 35 & 2.87 & 5.06 \\
\hline $\mathrm{LSD} \propto 0.05$ & & & & \\
\hline
\end{tabular}

,+++ ; Hybrid and Open pollinated variety (OPV) checks respectively. 
anthesis later than the two check varieties (Oba Super 2 and DMR-LSR-Y). However, ASI was shorter by 1-2 days for all genotypes compared to hybrid check. Acr 91 Suwan-1SR $\mathrm{C}_{1}$ and $\mathrm{AK}$ 9528-DMRSR rated better for stalk and root lodging while the OPV check was the worst for the two characters. The genotypes showed slight susceptibility to both blight and curvularial leaf diseases, ranging from $5.1 \%$ in Ikenne 88 TZSR-Y-1 to $8.1 \%$ in the OPV check for leaf blight and from $4.6 \%$ in IK 91 TZL Comp 3-Y C $\mathrm{C}_{1}$ to $8.4 \%$ also in the OPV check for curvularia leaf spot. However, the lowest incidence of leaf diseases recorded for Ikenne 88 TZSR-Y-1 and TZB-SR-SGY differed significantly only from that of the OPV variety.

Genotypic differences were significant only for grain yield, ENO and husk cover (Table 3). Oba super 2 ranked best for grain yield but did not differ in yield potential from any of the new generations of MSV resistant varieties. However, along with Acr. 91 Suwan-1-Sr C1 which ranked second for grain yield, this variety yielded higher than the OPV check by more than $32 \%$. The OPV check was also the latest to attain maturity as indicated by the highest grain moisture at harvest. Two of the new generations of MSV resistant varieties (TZB-SR-SGY and Ikenne 88 TZSR-Y-1) were superior for husk cover while the hybrid check had the worst rating for this character. The genotypes did not differ significantly for ear aspect, a subjective rating which includes factors such as yield, appearance of the grain and ear rot.

Means for the interactive effects of genotype by year ( $\mathrm{G} \times \mathrm{Y}$ ) was significant for ENO but not for grain yield (Table 4). Two genotypes (AK 9528-DMRSR and the OPV check (DMR-LSR-Y)) showed high disparity in ENO between the two years with differences of 7 and 9 ears/plot respectively. IK 91 TZL Comp 3-Y $\mathrm{C}_{1}$ was the most stable of all the entries for ENO, with a difference of one (1) ear between the two years. Genotypic differences for grain yield between the two years (although nonsignficant) were also high and it ranged from $13.3 \%$ in Ikenne 88 TZSR$\mathrm{Y}-1$ to $38.8 \%$ in AK-9528-DMRSR. Hybrid check also demonstrated instability of performance for grain yield with a difference of $37.4 \%$ yield loss in 2001 compared to 2002 .

\section{DISCUSSION}

Days to anthesis often reveal differences in maturity among genotypes but may also be a reflection of weather pattern (temperature, available soil moisture, etc.) during crop's reproductive phase, which may stimulate plants to speed up the process of maturation. The genotypes attained anthesis earlier by two (2) days in 2001 when rainfall dropped sharply compared to 2002 with even distribution during the latter part of the growing period. However, rating for ear aspect in the genotypes was better in 2001 when the volume of rainfall was low in October and November that year which also coincided with period of crop maturity compared to similar period in 2002.

Rainfall amount and distribution during the growing periods in the two years, played significant role in the expression of genotypes' potential in this study. For example, rainfall was evenly distributed throughout the flowering/grain filling period of September and October, 2002. This condition favoured accumulation, and translocation of photo-assimilates in the genotypes with corresponding bigger ear size in 2002, subsequently higher grain yield in all the genotypes. High soil moisture at maturity period also reduced termite infestation, consequently, lower stalk and root lodging. However, incidence of leaf blight was also higher in 2002, a condition that is often encouraged by high moisture during the growing period (Ekpo and Esuruoso, 1977; Agrios, 1988; Amadi, 1998). The desire of maize breeders is that increased grain yield would be associated with the streak resistant gene block accompanied by negligible changes, if any, in other traits (Fakorede et al., 2001). In this study, new generations of MSV varieties were superior to OPV check both for grain yield and incidence of leaf diseases, indicating that despite the yield improvement, the genes for resistance to the causal organisms have not been eroded. Nonsignificance $\mathrm{G} \times \mathrm{Y}$ interaction effect for grain yield could be attributed to instability in performance of AK 9528-DMRSR and OPV check (DMR-LSR-Y) which had poor yield in 2001 cropping season and which was also reflected in wide disparity in grain yields obtained from both genotypes in the two years.

\section{CONCLUSION}

The major focus in varietal evaluation is to identify superior genotypes that could replace existing cultivars and/or as sources of genes for the extraction of inbred lines aimed at development of productive varieties. Acr 91 Suwan-1-SR $\mathrm{C}_{1}$ was the most productive of the new generations of MSV resistant varieties with the highest yield advantage of 32 percent (\%) over the OPV check. It also compared favourably with the hybrid check for grain 
yield. The variety can therefore serve as useful replacement to DMRLSR-Y and also as source of genes for future maize breeding activities in the development of superior maize varieties for the southern guinea savanna ecology

\section{REFERENCES}

Agrios, N.G. 1988. Plant Pathology. Acad. Press, London. 803pp Amadi, J.E. 1998. The effects of growing season on Cercospora leaf spot diseaseseverity and grain yield. Centrepoint Science Edition 8 (1V): 47-55.

Ekpo, E.J. and O.F. Esuruoso. 1977. Factors affecting spore germination in cowpea isolate of Cercospora cruenta Sacc. Phytopathol 89:249-255.

Fajemisin, J.M. 1984. Basic constraints to maize productivity in tropical Africa. Paper presented at the U.S. Universities/CIMMYT maize conference. CIMMYT. Mexico. August 8-15, 1984.

Fajemisin, J.M. 1985. Maize diseases in Africa and their role in varietal improvement process. Paper presented at the Maize Regional Workshop for Eastern ands Southern Africa held at Lusaka, Zambia. March 10-17, 1985.

Fajemisin, J.M., M. Bjarnasan, S.K. Kim, Y. Efron and Z.T. Dabrowski 1984. Effect of maize streak virus on maize productivity. Paper presented at the $14^{\text {th }}$ conference of Nigeria Society for Plant Protection. University of Ibadan, Nigeria March 12-15, 1984.

Fajemisin, J. E.; Efron Y; Kim. S.K.; Khadr E.H; Dabroski Z. T. Mareck J.H. Bajarson M; Parkinson V; Everet, L. A and Daillo A., 1985. Population and varietal development in maize for tropical Africa through resistance breeding approach. In: Brandolini, A. and Salami, F. (eds). The strategies for maize production and Improvement in the tropics. FAO, Italy. pp. 285-408.
Fakorede, M.A.B., J.M. Fajemisin, J.L. Ladipo, S.O. Ajala and S.K. Kim. 2001. Development and regional deployment of streak virus maize germplasm: an overview. 503-516 in Jacqueline d'A Hughes and Babajide O Odu (eds). Plant Virology in SubSaharan Africa. Proc. of a conference organized by the International Institute of Tropical Agriculture, Ibadan $4^{\text {th }}-8^{\text {th }}$ June, 2001.

Mihm, J.A. 1994. Maize pest managementmultiple insect and disease resistant varieties are the key to success. 176181. in David C. Jewell, Stephen R. Waddington, Joel K. Ransom and Kevin V. Pixley (eds.) Maize research for stress environments. Proceedings of the Fourth Eastern and Southern Africa Regional Maize Conference Harare Zimbabwe. 28 $8^{\text {th }}$ March $-1^{\text {st }}$ April, 1994.

laokojo, S.A. and J.E. Iken. 1999. Productivity of maize genotypes in downy mildew endemic zone of south western Nigeria. Nigerian J. Genetics 14:6468

Olaokojo, S.A. and J.E. Iken. 2001. Yield performance and stability of some improved maize (Zea mays L.) varieties. Moor Journal of Agricultural Research 2:21-24.

Snedecor, G.W. and W.G. Cochran, 1967. Statistical Methods. Iowa States University Press, Ames Iowa, USA. 593pp.

Steel, R.G.D. and J.H. Torrie 1980. Principles and Procedures of Statistics. A Biometrical Approach. $2^{\text {nd }}$ Edition. McGraw Hill Book Inc. New York. 580pp. 
Agro-Science Journal of Tropical Agriculture, Food, Environment and Extension Volume 8 Number 2 Mav 2009 pp $110-115$

ISSN 1119-7455

\title{
INTRA- AND INTER- CORRELATIVE RESPONSES AMONG FRUITS PHYSICAL TRAITS, SEEDLING GROWTH PARAMETERS AND FRUIT AND NUT PROXIMATE QUALITIES OF THE NIGERIAN SHEA NUT TREE (VITELLARIA PARADOXA C. F. GAERTN)
}

\author{
Ugese $^{1}$, F D Baiyeri' ${ }^{2}$ K P and $\operatorname{Mbah}^{2}$ B N \\ ${ }^{1}$ Dept. of Crop Production, University of Agriculture, P M B 2373, Makurdi, Nigeria. \\ ${ }^{2}$ Dept. of Crop Science, University of Nigeria, Nsukka, Nigeria.
}

\begin{abstract}
Seedling growth of Vitellaria paradoxa C. F. Gaertn (shea nut tree) is extremely slow. Identification of any nut trait that shows positive and significant relationship with vigorous seedling growth could therefore, be an important selection index. Besides, fruit preferences among indigenous peoples are associated with high pulp proximate quality while highly valued nut has strong relationship with fat content. Thus, intra- and inter- correlative responses among fruits physical traits, seedling growth parameters and fruit and nut proximate qualities of $V$. paradoxa were studied. Agronomically important seedling characters of nine provenances across Nigeria's savanna zone were also examined with principal components analysis (PCA). Results indicated that the first three PCA axes retained explained $96.3 \%$ of total variability among seedling provenances, revealing that leaf area, seedling girth, plant height and number of leaves are more promising traits for shea seedling classification in Nigeria. Multiple correlation analysis showed that nut length had high and significant linkage with number of leaves, leaf width, leaf area and seedling girth. Nut width also correlated positively with leaf length, leaf area and seedling girth $(P<0.05)$. Percent pulp weight had high positive significant correlation with carbohydrate and energy, but was negatively correlated with fibre. Similarly, nut diameter had positive significant relationship with fat but a negative one with carbohydrate. Correlations between percent testa weight and fat were positive. The correlative responses showed that choice of long nuts for planting could lead to vigorous seedling growth. Similarly, shea fruits with high percent pulp content could have high carbohydrate and energy contents while nuts with broader diameters may be selected for high fat content.
\end{abstract}

Keywords: Shea nut tree, Correlations, PCA, , Proximate traits, Seedling traits, Vitellaria paradoxa

\section{INTRODUCTION}

Among the many trees in the family Sapotaceae, foremost economic species seem to be Vitellaria paradoxa, Baillonella toxisperma and Madhuca longifolia (Maranz et al., 2004), with V. paradoxa appearing to be of greater economic significance. The importance of the shea nut tree (Vitellaria paradoxa), most commonly called shea butter tree, on a global scale, is predicated on the usefulness of its seed fat in European and Japanese food and cosmetic industries (Umali and Nikiema, 2002). In Africa where the species occurs, the seed fat is used for cooking, in lighting of lamps, in soap and pomade preparations as well as for medicinal purposes (Awoleye, 1995; ICRAF, 2000; Hill, 1952). Other plant parts have been credited with various medicinal uses (Popoola and Tee, 2001).

In addition, caterpillars of Cirina butyrospermi, rich in protein and exclusive feeders on the leaves of the species, are considered a delicacy among some Nigerian ethnic groups such as the Yoruba and Nupe (Ande, 2004) and the Tiv of Central Nigeria (Ugese et al., 2005). Sale of these caterpillars is said to contribute significantly to rural household incomes (Popoola and Tee, 2001). The wood of $V$. paradoxa is hard and termite proof and is useful in constructional works and in the production of household and farm items. The fruit pulp has excellent nutritional properties and is widely consumed among indigenous peoples (Maranz et al., 2004; Ugese et al., 2008).

Agroforestry species that show high potential in contributing to reduction of rural poverty, hunger and disease and enhancing environmental sustainability are considered priority species for domestication (Leakey et al., 2005). The high rating of $V$. paradoxa in terms of the above potentials qualified it for inclusion among the 17 
priority species that have been farmer-identified for domestication in four eco-regions of the tropics (Leakey, 1999). A key consideration in agroforestry tree domestication effort is the identification of genetic variability within the species, and the relationships between or among those traits as an aid towards selection of superior genotypes (Leakey et al., 2005). According to Sanwo (1980), if an easily observable trait positively and significantly correlates with an obscure but useful trait, then the former could be used as a basis for selection for the latter. This indicator trait approach could become even more useful if the easily observable or measurable trait correlates with two or more traits of economic significance.

In Vitellaria paradoxa, seedling growth is extremely slow (Jackson, 1968). Therefore, any nut trait that would have a positively significant correlative link with vigorous seedling growth could be an asset. Similarly, fruit preferences among indigenous peoples have been documented, with farmers showing preference for sweet, fleshy and ripe fruits (de Saint Sauveur, 1999). As far as fat extraction and its utilization are concerned, a key criterion for identifying a good nut is the fat content (Maranz et al., 2004). Working out the relationships between these set of traits will enable all kinds of useful selections to be done. Therefore, this study was undertaken to identify the nature, and then quantify the degree of relationship [i] between fruit and nut traits; [ii] between seedling traits and nut traits, and [iii] between fruit pulp and kernel proximate traits, of the shea nut tree across Nigeria's savanna ecology.

\section{MATERIALS AND METHODS}

Fresh fruits of the shea nut tree were collected across the guinea and sudan savanna of Nigeria in early July, 2006. The specific locations of collection were Ilorin, Lokoja, Makurdi, Akwanga, Minna (southern guinea savanna), Kachia, Jalingo (northern guinea savanna), Yola and Kano (sudan savanna). The fruits were depulped to obtain the seeds.

Fruits and nuts were divided into five groups of forty five, with each group representing a replicate. Metric traits of the fruits and nuts were then taken. Trait means resulting from the analysis of variance were used for this study.

A provenance evaluation trial was set up at the Teaching and Research Farm of the University of Agriculture, Makurdi $\left(7^{\circ} 41^{\prime} \mathrm{N}, 8^{\circ} 37^{\prime} \mathrm{E}, 97 \mathrm{~m}\right.$ above sea level) on 26th July, 2006. Seeds were planted at $50 \times 20 \mathrm{~cm}$ spacing in single row plots of ten seeds each. The experimental design was randomized complete block (RCBD) replicated four times. A replicate trial was set up at the farm of the Department of Crop Science, University of Nigeria, Nsukka $\left(6^{\circ} 51^{\prime} \mathrm{E}, 7^{\circ} 29^{\prime} \mathrm{N}, 400 \mathrm{~m}\right.$ above mean sea level). Makurdi is in the southern guinea savanna zone while Nsukka falls within the derived savanna zone of Nigeria.

Twelve (12) months after sowing, seedling growth characters were measured. Analysis of variance was carried out on the data as a $2 \times 9 \times 4$ factorial in RCBD with location (2) and genotypes (9) as the factors. Means of seedling characters resulting from the main effects of the factors were utilized in the correlation analysis.

Oven dry weights of fruit pulp were subjected to proximate trait determinations based on laboratory procedures outlined by the Association of Official Analytical Chemists (AOAC, 1980). Energy was determined using the Atwater method (Joslyn, 1970). Similar procedures as above were employed for determination of seed kernel proximate traits. Means obtained from analysis of variance were used for the correlation study.

Seedling traits were examined with Principal Component Analysis (PCA) to identify those traits with greater promise for shea seedling classification in Nigeria. Furthermore, correlations among the seedling traits were also determined.

Fruit and nut means were correlated with seedling growth means, pulp proximate trait means and kernel proximate trait means. Statistical software employed for the correlation analysis was SPSS version 11 while GENSTAT Discovery edition 3, Release 7.2DE (GENSTAT, 2007) was used for the analysis of variance.

\section{RESULTS}

Results of Principal Components Analysis (PCA) performed on the data showed that the three principal axes retained explained $96.3 \%$ of the total variability among growth characters of seedlings of the various provenances (Table 1). The first axis (PRIN 1) accounted for $73.2 \%$ of the total variability and was loaded for leaf dimension parameters and plant girth. PRIN 2 which loaded highly for plant height explained about $15.6 \%$ of the total variability. It was observed that number of leaves per seedling could explain up to $7.5 \%$ (PRIN 3) variance found in shea seedling. Generally, PCA identified leaf area, leaf length, seedling girth, plant height and number of leaves as showing greater prospect as discriminant variables for shea seedling classification in Nigeria.

Intra-correlations among the seedling growth traits showed that number of leaves had positive significant relationship with leaf area and leaf width (Table 2). Similarly, length of leaf revealed 
Ugese, F D Baiyeri K P and Mbah B N

Table 1. Eigen vector values for principal components of seedling characters of nine accessions of the shea nut tree grown at Makurdi and Nsukka in Nigeria.

\begin{tabular}{lllllllll}
\hline Principal Axis & $\begin{array}{l}\text { Leaf } \\
\text { area }\end{array}$ & $\begin{array}{l}\text { Leaf } \\
\text { Length }\end{array}$ & $\begin{array}{l}\text { Leaf } \\
\text { width }\end{array}$ & $\begin{array}{l}\text { Number } \\
\text { of leaves }\end{array}$ & $\begin{array}{l}\text { Plant } \\
\text { height }\end{array}$ & $\begin{array}{l}\text { Seedling } \\
\text { girth }\end{array}$ & $\begin{array}{l}\text { Latent } \\
\text { roots }\end{array}$ & $\begin{array}{l}\text { Percentage of } \\
\text { total variation } \\
\text { explained }\end{array}$ \\
\hline PRIN 1 & $\mathbf{- 0 . 4 5 7 1 5}$ & $\mathbf{- 0 . 4 5 6 7 0}$ & -0.38860 & -0.34357 & -0.31552 & $\mathbf{- 0 . 4 6 2 4 2}$ & 4.392 & 73.20 \\
PRIN 2 & 0.28416 & 0.03447 & 0.52561 & -0.52537 & $\mathbf{- 0 . 6 0 3 1 2}$ & 0.04518 & 0.935 & 15.58 \\
PRIN 3 & -0.05421 & -0.18383 & 0.16731 & $\mathbf{- 0 . 6 6 2 6 3}$ & 0.69539 & 0.11238 & 0.451 & 7.52 \\
\hline
\end{tabular}

Table 2. Correlations among seedling characters of nine accessions of the shea nut tree grown at Makurdi and Nsukka in Nigeria

\begin{tabular}{|c|c|c|c|c|c|c|c|c|}
\hline & No. of leaves & Leaf length & Leaf width & Leaf area & $\begin{array}{l}\text { Petiole } \\
\text { Length }\end{array}$ & Plant height & $\begin{array}{l}\text { Seedling } \\
\text { girth }\end{array}$ & $\begin{array}{l}\text { Leaf shape } \\
\text { index }\end{array}$ \\
\hline Leaf shape index & 0.652 & $0.954 * *$ & 0.754 & $0.833 * *$ & $0.801^{*}$ & 0.669 & $0.885 * *$ & - \\
\hline Seedling girth & $0.831 *$ & $0.834^{*}$ & $0.915^{* *}$ & $0.920 * *$ & 0.656 & 0.709 & - & \\
\hline Plant height & 0.641 & 0.532 & 0.444 & 0.502 & 0.503 & - & & \\
\hline Petiole length & 0.387 & $0.833^{*}$ & 0.490 & 0.557 & - & & & \\
\hline Leaf area & $0.837^{*}$ & $0.772 *$ & $0.986 * *$ & - & & & & \\
\hline Leaf width & $0.881 * *$ & 0.698 & - & & & & & \\
\hline Leaf length & 0.559 & - & & & & & & \\
\hline No of leaves & - & & & & & & & \\
\hline
\end{tabular}

Table 3. Correlations between metric traits of fruits and nuts and seedling growth traits of the shea nut tree from the savanna of Nigeria.

\begin{tabular}{|c|c|c|c|c|c|c|c|c|c|c|c|c|}
\hline \multirow{2}{*}{$\begin{array}{l}\text { Seedling } \\
\text { growth } \\
\text { traits } \\
\end{array}$} & \multicolumn{12}{|c|}{ Metric traits of fruits and nuts } \\
\hline & FRLT & FRDM & FSI & FRWT & PUPWT & \%PUPWT & NTWT & NTLT & NTDM & NSI & KNWT & $\% \mathrm{TSWT}$ \\
\hline No of leaves & $0.805^{*}$ & 0.695 & 0.490 & 0.706 & 0.599 & -0.226 & 0.714 & $0.777 *$ & 0.493 & 0.064 & 0.650 & -0.060 \\
\hline Leaf length & 0.169 & 0.022 & 0.114 & 0.171 & -0.110 & $-0.860 *$ & 0.605 & 0.678 & $0.808^{*}$ & -0.649 & 0.657 & 0.423 \\
\hline Leaf width & 0.623 & 0.677 & 0.198 & $0.786^{*}$ & 0.615 & -0.419 & $0.884 * *$ & $0.798 *$ & 0.703 & -0.307 & 0.680 & -0.126 \\
\hline Leaf area & 0.526 & 0.553 & 0.196 & 0.687 & 0.495 & -0.528 & $0.846^{*}$ & $0.771 *$ & 0.727 & -0.407 & 0.674 & -0.093 \\
\hline Plant height & 0.395 & 0.04 & $0.776^{*}$ & 0.034 & -0.089 & -0.504 & 0.234 & 0.503 & 0.275 & -0.014 & 0.543 & 0.169 \\
\hline Seedling & 0.496 & 0.398 & 0.365 & 0.540 & 0.312 & -0.673 & $0.794 *$ & $0.838 *$ & $0.765^{*}$ & -0.434 & 0.797 & 0.097 \\
\hline
\end{tabular}

FRLT $=$ Fruit length FRDM = Fruit diameter; FSI = Fruit shape index; FRWT = Fruit weight; PUPWT = Pulp weight; PUPWT $(\%)=$ Percentage pulp weight; NTWT $=$ Nut weight NTLT $=$ Nut length $;$ NTDM $=$ Nut diameter; NSI $=$ Nut shape index; KNWT $=$ Kernel weight; \% TSWT $=$ Percentage testa weight.

$*$, ** - Correlation is significant at the $5 \%$ and $1 \%$ levels of probability respectively

positive statistical linkage with leaf shape index, seedling girth, petiole length and leaf area $(\mathrm{P}<0.05)$. In addition to having high and significant relationship with number of leaves and leaf length, leaf area also maintained such relationship with leaf shape index and seedling girth. Plant height had positive but nonsignificant relationships with all the other seedling growth traits. Seedling girth recorded high positive correlations with leaf dimensions parameters.

The inter-correlation among fruits and nuts metric traits and seedling traits are shown in Table 3. Fruit length exhibited high significant linkage with number of leaves while fruit weight maintained such relationship with leaf width. Percentage pulp weight had a negative relationship with leaf length $(\mathrm{P}<0.05)$. Among all the fruit and nut traits, only fruit shape index had positive significant relationship $\left(\mathrm{r}=0.776^{*}\right)$ with plant height.

Among nut metric traits, nut weight correlated positively with leaf length, leaf area and seedling girth. Nut length had the highest number of significant linkages with seedling characters as it maintained such relationship with number of leaves, leaf width, leaf area and seedling girth. Nut diameter was also positively correlated with leaf length and seedling girth. Kernel weight similarly 
Table 4. Correlations between physical traits of fruits and nuts and pulp proximate traits Vitellaria paradoxa sourced from the savanna of Nigeria.

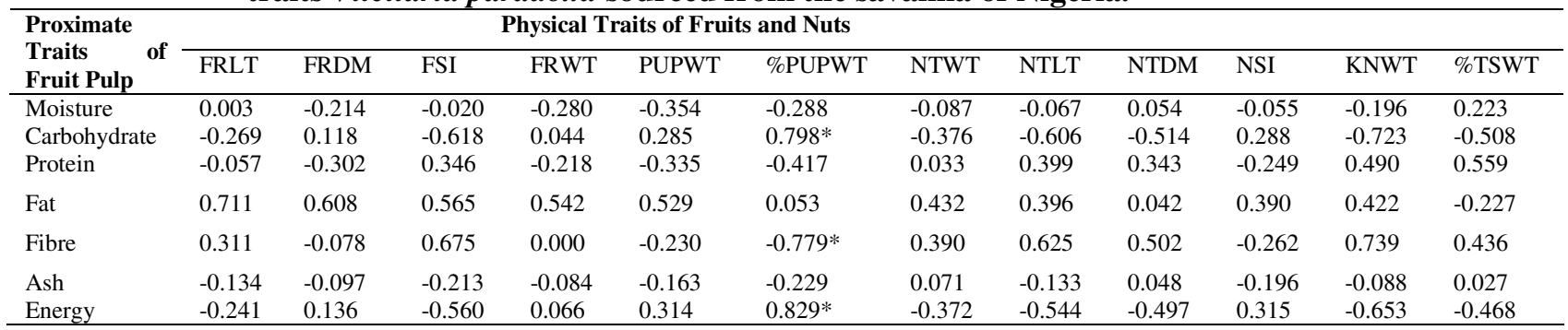

FRLT = Fruit length; FRDM = Fruit diameter; FSI = Fruit shape index $;$ FRWT $=$ Fruit weight $;$ PUPWT = Pulp weight; $\%$ PUPWT $=$

Percentage pulp weight;

NTWT = Nut weight; NTLT = Nut length; NTDM = Nut diameter; NSI = Nut shape index; KNWT = Kernel weight; \%TSWT =

Percentage testa weight.

*- Correlation is significant at the $5 \%$ level of probability.

Table 5. Correlations between physical traits of fruits/nuts and proximate traits of kernels of Vitellaria paradoxa sourced from the savanna of Nigeria.

\begin{tabular}{|c|c|c|c|c|c|c|c|c|c|c|c|c|}
\hline \multirow{2}{*}{$\begin{array}{l}\text { Proximate } \\
\text { Traits of } \\
\text { Kernel }\end{array}$} & \multicolumn{9}{|c|}{ Physical Traits of Fruits and Nuts } & \multirow[b]{2}{*}{ NSI } & \multirow[b]{2}{*}{ KNWT } & \multirow[b]{2}{*}{$\% \mathrm{TSWT}$} \\
\hline & FRLT & FRDM & FSI & FRWT & PUPWT & \%PUPWT & NTWT & NTLT & NTDM & & & \\
\hline Moisture & 0.145 & 0.207 & 0.161 & 0.126 & 0.324 & 0.639 & -0.242 & -0.102 & -0.369 & 0.508 & -0.129 & -0.234 \\
\hline Carbohydrate & 0.005 & -0.141 & 0.346 & -.314 & -0.069 & 0.519 & -0.654 & -0.733 & $-0.905 * *$ & 0.698 & -0.745 & -0.718 \\
\hline Protein & 0.063 & -0.241 & 0.398 & -.382 & -0.270 & 0.246 & -0.479 & -0.174 & -0.382 & 0.485 & -0.209 & 0.158 \\
\hline Fat & -0.129 & -0.055 & -.396 & 0.080 & -0.169 & -0.575 & 0.483 & 0.528 & $0.777^{*}$ & -0.678 & 0.542 & $0.767 *$ \\
\hline Fibre & 0.058 & 0.363 & -.248 & 0.584 & 0.423 & -0.413 & 0.713 & 0.482 & 0.640 & -0.655 & 0.509 & -0.182 \\
\hline Ash & 0.408 & 0.553 & 0.278 & 0.481 & 0.671 & 0.630 & 0.039 & -0.046 & -0.379 & 0.568 & -0.047 & -0.650 \\
\hline Energy & -0.186 & -0.222 & -.334 & -.143 & -0.366 & -0.546 & -0.271 & 0.359 & 0.606 & -0.551 & 0.368 & $0.818^{*}$ \\
\hline
\end{tabular}

FRLT $=$ Fruit length FRDM $=$ Fruit diameter; FSI = Fruit shape index; FRWT = Fruit weight; PUPWT = Pulp weight; \%PUPWT = Percentage pulp weight;

NTWT = Nut weight; NTLT = Nut length; NTDM = Nut diameter; NSI = Nut shape index; KNWT = Kernel weight; $\%$ TSWT = Percentage testa weight.

*, ** - Correlation is significant at the $5 \%$ and $1 \%$ levels of probability respectively.

recorded high positive relationship with seedling girth $(\mathrm{P}<0.05)$.

There were few significant relationships between physical traits of fruits and nuts and pulp proximate characters (Table 4). Percentage pulp weight significantly correlated positively with carbohydrate and energy, but negatively with fibre. Apart from percent pulp weight, other physical attributes did not show significant relationship with any of the pulp proximate qualities. However, the relationship between fibre and kernel weight was positive $(r=0.739)$. Similarly, proportion of fat in the fruit pulp was associated $(\mathrm{r}=$ 0.711) with increasing fruit length.

A few significant relationships were observed between fruit and nut physical traits and proximate traits of kernel (Table 5). The nut diameter was negatively but significantly correlated with carbohydrate $\left(\mathrm{r}=-0.905^{* *}\right)$. However, nut diameter had positive significant relationship $\left(\mathrm{r}=0.777^{*}\right)$ with fat. The percent testa weight was positively correlated with fat and energy $(\mathrm{P}<0.05)$.

\section{DISCUSSION}

The vector loadings of the three principal axis retained in the PCA conducted suggested that leaf parameters (number of leaves, leaf area, leaf length) and seedling girth are the most important selection indices for shea seedlings in Nigeria. The significant intra- and intercorrelations among several parameters as obtained in this study corroborate earlier report of Ugese et al. (2005). However, in the present study, an important contrast was the nonsignificant relationship between plant height and other seedling growth parameters. It could be due to the influence of genotype $x$ environment $\left(\begin{array}{lll}g & x & e\end{array}\right)$ interaction on this particular trait as nine genotypes were assessed over two contrasting environments. In the earlier study under reference, only one seed source, planted in a single location was involved, thereby precluding any possibility of $\mathrm{g} x$ e interaction.

Some key nut traits correlated positively and significantly with one or more aspects of seedling growth. This implies that selecting 
seeds for planting on the basis of the indicator traits could boost seedling growth attributes. For instance, if seeds of longer length are planted this will lead to seedlings with high number of leaves, broader leaf width, larger leaf area and bigger stem girth. The positive significant correlations among these seedling traits (Table 2) reinforces the idea that planting

suitable seeds will produce seedlings that will show vigour in many aspects of seedling growth. For instance, nut length did not show any significant relationship with leaf width (Table 3). However, stem girth did (Table 2). Thus planting long seeds could lead to seedlings with larger stem girth and consequently larger leaf width as well.

It is highly advantageous that nut length recorded the highest number of significant correlations with seedling growth traits. This is because even when nuts are bulked together under post harvest conditions, it might be easier to undertake selection on the basis of nut length rather than nut width or weight.

An important practice in agroforestry tree domestication is the use of various vegetative propagation techniques to disseminate germplasm of superior individuals (Leakey et al., 2005). In Vitellaria, this has started happening (Maranz et al., 2004). However, the method that has been found successful is grafting in which young saplings are used as the root stock (Spore 2008). Since growth of shea seedlings is extremely slow (Jackson, 1968), any choice of seed that could accelerate seedling growth would be a positive development. This could reduce the age at which saplings are grafted, thereby helping to reduce further the age of fruiting occasioned by the technique.

The significant positive correlation between percentage pulp weight and carbohydrate showed that this class of food was dominant in such fruit pulps. Ugese et al. (2008) reported that shea fruits in the wetter savanna zone of Nigeria had more percentage pulp and carbohydrate contents than those in the drier zone. They attributed this to more favourable environmental conditions that enhance optimal rates of photosynthesis. Stress conditions may result in low percentage pulp content that could be more fibrous as correlation analysis also indicated in this study.

The positive significant correlation between nut diameter and kernel fat content may be an indication that wider seeds could contain more fat than narrower ones. The carbohydrate content of such seeds could be less as this character (nut diameter) was negatively correlated with carbohydrate content. From the description of cellulose or lingo-cellulose by Roberts (1976), it seems likely that the testa is made up of this material. If this is the case, it implies that part of the carbohydrate was used in forming the testa. This, therefore, could have the effect of reducing the amount of carbohydrate inside the kernel thereby indirectly increasing that of fat and other components. Thus, seeds with higher percentage testa weight would invariably maintain high amount of fat which is the dominant kernel content. This feature may explain the significant positive linkage between percentage testa weight and carbohydrate content (Table 4). Since fat is apparently the major determinant of kernel energy content, the relationship between energy and percent testa weight was equally positive.

Generally, the nature of relationships observed between physical traits of fruits and nuts and also between proximate traits of kernel and fruit pulp corroborates the findings of Leakey et al. (2005), in three key agroforestry species - Dacryodes edulis, Irvingia gabonensis and Sclerocarya birrea who noted that high values of one trait may not necessarily be associated with high values of another trait. In other words, large fruits, for instance, may not necessarily be sweet or contain large nuts or kernels. In this study, large fruits, for instance, did not record high percentage pulp content and fruit weight did not also exert any appreciable influence over any of the pulp proximate qualities. In cashew, Sanwo (1980) obtained negligible number of significant correlations between fruit and nut physical characters and fruit chemical attributes.

Based on the results of the study, the following conclusions and recommendations are stated below:

(i). Principal components analysis identified leaf area, leaf length, seedling girth, plant height and number of leaves as more promising traits for shea seedling classification. This suggests that leaf dimension and stem growth are key selection indices for identification of vigorous accessions at seedling growth stage of shea;

(ii). Nuts that were long were significantly associated with vigorous seedling growth. This implies that initial selection of long nuts for nursery planting will invariably produced vigorous and healthy seedlings; 
Correlative Responses Among Fruits Physical Traits, Growth and Quality

(iii). Shea fruits with high percentage pulp contents are associated with higher carbohydrate and energy content;

(iv). Nuts with wider diameters may contain more fat than those with narrower diameters.

\section{REFERENCES}

Ande, A T. (2004). The pupal habits of Cirina fordea, a leading food insect in Kwra State Nigeria. J. Sustainable TropAgric Res 9:97-100.

AOAC (1980). Official Methods of Analysis (Fourth edition). Association of Official Analytical Chemists, Washington DC, USA.

Awoleye F., (1995). Effects of seed sources on the growth of seedlings of Vitellaria paradoxum in the Southern Guinea Savanna of Nigeria. Nig J. Bot. 8:6569

de Saint Saurveur, A. (1999). Indigenous management practice of farmed parklands, In: Teklehaimanot, $\mathrm{Z}$. (Ed). Improved Management of Agroforestry Parkland Systems in sub-Saharan Africa. First Annual Report, 1 October 1998-30. September, (1999). School of Agricultural and Forest Sciences, University of Wales, Bangor, U. K.

GENSTAT, (2007) GENSTAT Discovery Edition 3, Release 7.2DE. Lawes Agricultural Trust, Rothamstead Experimental Station, UK

Hill, A.F. (1952) Economic Botany: A Textbook of Useful Plants and Plant Products, $2^{\text {nd }}$ Edition. McGraw-Hill Books Co., New York. 560pp.

ICRAF. (2000). International Centre for Research in Agroforestry. Agroforestry Database 2000.

Jackson, G. (1968). Notes on West African Vegetation-III: the seedling morphology of Butyrospermum paradoxum. Journal of West African Science Association 13:215-22.

Joslyn M.A. (1970) Methods of Food Analysis (Second Edition). Academic Press. 560pp.

Leakey, R.R. 1999. Potential for novel food products from agroforestry trees: A review: Food Chemistry 66:1-14.

Leakey, R.R.B., Tchoundjei, E., Schreckenberg, K., Shackleton, S. E. and Shacketon, C.M. (2005). Agroforestry tree products (AFTPs): targeting poverty reduction and enhanced livelihoods. International
Journal of Agricultural Sustainability 3(1): 1-23.

Maranz S., Kpikpi, W., Wiesman, Z., Saint Sauveur, A. and Chapagain, B. (2004). Nutritional values and indigenous preferences for shea fruits (Vitellaria paradaxa C.F. Gaertn. F. ) in African agrofoestry parklands. Economic Botany 58:588-600.

Popoola, L. and Tee, N.T. (2001). Potentials of Vitellaria Paradoxa Gaertn F. in Agroforstry systems in Benue state. Nigerian Journal of Ecology 16:2024.

Roberts, M.BV (1976). Biology: A functional Approach (Second Edition). Thomas Nelson and Sons Ltd. Singapore 656pp.

Sanwo, J.O. (1980) Correlation coefficients between ;fruit' traits as possible aids in the selection of desirable cashew (Anacardium occidentale L.) Nigerian Journal of Science 14:225-233.

Spore (2008). Grafted shea tree: a prolific double. Spore No. 135, June, 2008. $16 \mathrm{pp}$.

Ugese, F.D. Ojo A.A. and Bello, L.L. (2005). Effect of presowing treatment and nut orientation on emergence and seedling growth of seeds of shea butter tree (Vitellaria paradoxa). Nigerian Journal of Botany 18:294304.

Ugese, F. D., Baiyeri, K. P. and Mbah, B. N. (2008). Nutritional composition of shea (Vitellaria paradoxa) fruit pulp across its major distribution zones in Nigeria. Fruits 63:163-169

Umali, B.E. and Nikiema. A. (2002). Vitellaria paradoxa C.F. Gaertn. Record from Protabase. Oyen, LP A and Lemmens, RHMJ (Editors) PROTA,

Wageningen, the Netherlands. 
Agro-Science Journal of Tropical Agriculture, Food, Environment and Extension Volume 8 Number 2 May 2009 pp 116-120

ISSN 1119-7455

\title{
EVALUATION OF FRUIT AND BUNCH TRAITS IN BLACK SIGATOKA RESISTANT PLANTAIN AND BANANA HYBRIDS
}

\author{
Adeniji, Tajudeen Adebayo $^{1}$, Barimalaa, Iminabo Samuel ${ }^{2}$ and Tenkouano, Abdou ${ }^{1}$ \\ ${ }^{1}$ International Institute of Tropical Agriculture, P.M.B. 5320, Oyo Road, Ibadan, Nigeria. \\ ${ }^{2}$ Department of Food Science and Technology, Rivers State University of Science and \\ Technology, P.M.B. 5080, Nkpolu, Port Harcourt, Nigeria.
}

\begin{abstract}
Studies involving the evaluation of fruit and bunch characteristics of twenty seven cultivars of plantain and banana were undertaken. Results showed that bunch weight of plantain hybrid, 25344-18, differed significantly $(P<0.05)$ from all other genotypes except $S H 3362$, with an average of $20.8 \mathrm{~kg}$ plant ${ }^{1}$. The number of hands and fruits bunch ${ }^{-1}$ for 9128-3, SH 3362, 25291-S32 and 25344-18 were significantly different $(P<0.05)$ from plantain landraces (Agbagba and Obino l'Ewai). Agbagba differed significantly $(P<0.05)$ from the rest of the genotypes both in fruit weight and fruit volume. There was a high significant difference $(P<0.05)$ in fruit weight and fruit volume between a banana hybrid, 5295-1, and all other hybrids, and Obino l'Ewai. Highly significant positive correlation $(P<0.01)$ was observed between bunch weight and the number of hands, number of fruits bunch ${ }^{-1}$, as well as fruit volume. The same trend was observed in the number of hands bunch $^{-1}$ and number of fruits hand, and also between fruit weight and fruit volume. A high negative correlation $(P<0.01)$ was observed between number of fruits and fruit weight and volume. There was no correlation between number of hands and fruit weight, and number of hands and fruit volume. These findings suggest that new Musa hybrids are highly promising in terms of yield and certain fruit and bunch traits and could therefore complement African traditional plantains.
\end{abstract}

Key words: Black Sigatoka resistant, hybrid, evaluate, yield components, post harvest.

\section{INTRODUCTION}

The main centres of plantain and banana cultivation in Africa are the wet tropical zones of West and Central Africa and the East African Highlands (IPGRI, 1999). World production of plantain is approximately 24 million tons of which 17 million tons representing $70.8 \%$ are produced in Africa (FAO, 1987). The overriding constraints to plantain and banana production are decreasing soil fertility, yield decline phenomenon, pest (weevils and nematodes) problems and most importantly, the widespread leaf spot disease called black Sigatoka (IITA 1992; Stover and Simmonds, 1987). Mycosphaerella musicola Leach and Mycosphaerella fijiensis are respectively the casual agents of yellow Sigatoka and black Sigatoka in Musa (Fullerton, 1994). Black Sigatoka is a virulent air borne fungal leaf spot disease, which can reduce plantain yield by up to $30-50 \%$ (Stover, 1983; INIBAP, 1987). The fungal pathogen, Mycosphaerella fijiensis Morelet, attacks the leaves, causing severe defoliation by leaf necrosis (Stover, 1983).

The International Institute of Tropical Agriculture (IITA) has acknowledged that black Sigatoka disease is the most critical research issue for plantain and banana in Africa. The Plantain and
Banana Improvement Programme was established by IITA following the identification of black Sigatoka disease of plantain in 1986. Consequently, plantain was added to the institute's list of mandated crops in 1987 and plans to combat black Sigatoka through both short-term and long-term strategy was initiated (IITA 1988). The short-term agenda consists of the identification, rapid in vitro multiplication, and distribution of black Sigatoka-resistant cooking bananas (Musa spp., ABB group) from Southeast Asia to farmers in the worst affected areas (Hahn et al., 1990; Ferris et al., 1994). Based on the experience of IITA banana breeding programme, the second approach, which involves breeding for resistant genotypes was anticipated to be a long-term project. This involves the breeding for black Sigatoka resistance hybrids. To this end, IITA have bred many cultivars of Musa hybrids which combines high yield with disease resistance. Tetraploid hybrids that are derived from different crosses produced heavier bunch compared to their parents (Vuylsteke et al. 1997). However, the introgression of genes of bananas may alter fruit quality characteristics in the hybrids, which may in turn affect consumer acceptability. Some of 
Fruit And Bunch Traits in Black Sigatoka Resistant Plantain and Banana Hybrids

the newly developed hybrids are currently undergoing field trials in multi-ecological locations through the National Agricultural Research and Extension Systems (NARES) in Nigeria. Research is therefore required to examine the yield and post harvest traits in the new hybrids to ensure successful introduction of the new hybrids to the end users.

Most producers and consumers of plantain and banana usually prefer large size bunches with large or small size fruit and/or long or short fruit, depending on the locality or country (Dadzie and Orchard, 1997). Therefore, assessment of bunch weight and fruit characteristics is important post harvest selection criterion. Bunch weight and number of hands per bunch (Stover and Simmonds, 1987) are important pomological characteristics from the standpoint of quality specifications. The number of fruits per hand is fairly constant from the fourth to the last hand, while fruit grade and finger length decrease linearly from the fourth to the last or apical hand (Stover and Simmonds, 1987). The size and weight of fruits are important parameters in determining their marketability. Fruit physical measurements such as bunch traits (weight and number of hands per bunch) are used to evaluate yield and response to experimental treatments (Stover and Simmonds, 1987). In addition, screening of new Musa hybrids for their fruit characteristics at harvest may be important in the design of packaging for the fruit, which would enhance efficient handling and transportation (Dadzie and Orchard, 1997). The objective of this present study was to determine yield and establish relationship between yield and these traits, which may be useful in selection and adoption.

\section{MATERIALS AND METHODS}

Twenty seven Musa genotypes consisting of plantain and banana hybrids and landraces were used for this study. These included twenty three plantain hybrids: 7152-2, 7152-2 OP15, 15108-6, 23688-2, 23898-3, 23977-7, 24044-3, 24364-S10, 25273-1, 25291-S26, 25291-S32， 25291-S41， 25333-S66, 25333-S88, 25333-S90, 25344-18, 25447-S7, 25502S4, 25729-5, A10-SPS 548-9, A5-SPS 548-9, five banana hybrids: 5295-1, 9128-3, 24408-S22, SH 3362, and two African plantain landraces: Agbagba, and Obino l'Ewai. FHIA stands for Fundación Hondureña de Investigación Agrícola based in Honduras. Bunches were obtained from the experimental station of the International Institute of Tropical Agriculture, High Rainfall Station, Onne, located on Latitude $04^{\circ}$ $43^{\prime} \mathrm{N}$, Longitude $07^{\circ} 01^{\prime} \mathrm{E}$ and $10 \mathrm{~m}$ Altitude, near Port Harcourt, Nigeria. Bunch samples were harvested at full maturity. Three bunches of each cultivar were sampled. Each bunch was weighed with the peduncle attached, but with the male bud and pseudostem cutoff closed to the distal end (last hand) of the bunch. Bunch traits (total number of hands and fruits) were also determined. The number of hands and fruits were obtained by counting the number of hands and fruits on each bunch. Fruits from the second and third hands were used to determine fruit weight and fruit volume. The maturity of hands in the bunch varies slightly: those at the proximal end of the bunch are usually more mature than those at the distal end. The estimate of maturity is based on the fullness of fruit of the middle hand (Thompson and Burden, 1995). Measurements were made immediately after harvest. Fruit weigh and fruit volume was determined using the method described by Dadzie and Orchard (1997). Mean fruit weight was determined by weighing ten different fruits and averaging the weights. The volume of fruit is obtained by direct volume displacement. A $2000 \mathrm{ml}$ (2 litres) measuring cylinder was filled with water, allowing enough space for fruit submersion. A fruit whose weight has been previously determined was then submerged. The final volume was subtracted from the initial volume, to obtain the actual fruit volume. All data analysis was performed using Statistical Analysis Systems (SAS, 1996) software package. Analysis of variance (ANOVA) was used to test for differences among samples. The Least Significant Difference (LSD) Test was employed to separate sample means that were significantly different at $5 \%, 1 \%$ and $0.1 \%$ level of probability.

\section{RESULTS}

Bunch weight and fruit traits at harvest are presented in Table 1 showing considerable genotypic variations in bunch weight and its components. Some of the plantain and banana hybrids performed better than the landraces. Specifically, 25344-18, a plantain hybrid, differed significantly $(\mathrm{P}<0.05)$ from the other hybrids and plantain landraces, with a mean weight of $20.8 \mathrm{~kg}^{-1}$ plant $^{-1}$. Amongst the banana hybrids, bunch weights were considerably higher in SH $3362(19.2 \mathrm{~kg}$ plant $^{-1}$ ) followed by $5295-1$ with $15.9 \mathrm{~kg}^{-1}$ plant $^{-1}$. The least bunch weight was $8.5 \mathrm{~kg}^{-1}$ plant $^{-1}$ for $24408-\mathrm{S} 22$. Two plantain landraces, Obino l'Ewai and Agbagba had bunch weights of 14.7 and $9.1 \mathrm{~kg} \mathrm{plant}^{-1}$, respectively. The mean number of hands bunch ${ }^{-1}$ were higher in the banana hybrids, particularly 9128-3 with 18 hands bunch $^{-1}$ and SH 3362 having 14 hands bunch ${ }^{-1}$ than the other hybrids investigated. These cultivars alongside plantain hybrids 25291-S32 (13 hands bunch ${ }^{-1}$ ), and 25344-18 (11 hands bunch ${ }^{-1}$ ) differed significantly $(\mathrm{P}<0.05)$ with traditional plantains. There was a significant difference $(\mathrm{P}<0.05)$ between the hybrids 9128, SH 3362, 25291-S32 and 25344-18 and local plantains in total number of fruits per bunch.

Comparisons of genotypes for fruit weight and fruit volume are presented in Table 2. Agbagba, a plantain landrace differed significantly $(\mathrm{P}<0.05)$ from the rest of the cultivars both in fruit weight and fruit volume. From the correlation data in Table 3, a high significant positive correlation $(\mathrm{P}<0.01)$ was exhibited between the bunch weight and the number of hands, fruits bunch ${ }^{-1}$, as well as fruit volume. As expected, the 
same trend was observed in the number of hands bunch $^{-1}$ and number of fruit hand ${ }^{-1}$, and between fruit weight and fruit volume. A high negative correlation $(\mathrm{P}<0.01)$ was observed between number of fruit and fruit weight and volume. However, there was no correlation between number of hand and fruit weight, and number of hand and fruit volume.

Table 1. Bunch traits for a selection of Musa hybrids at harvest

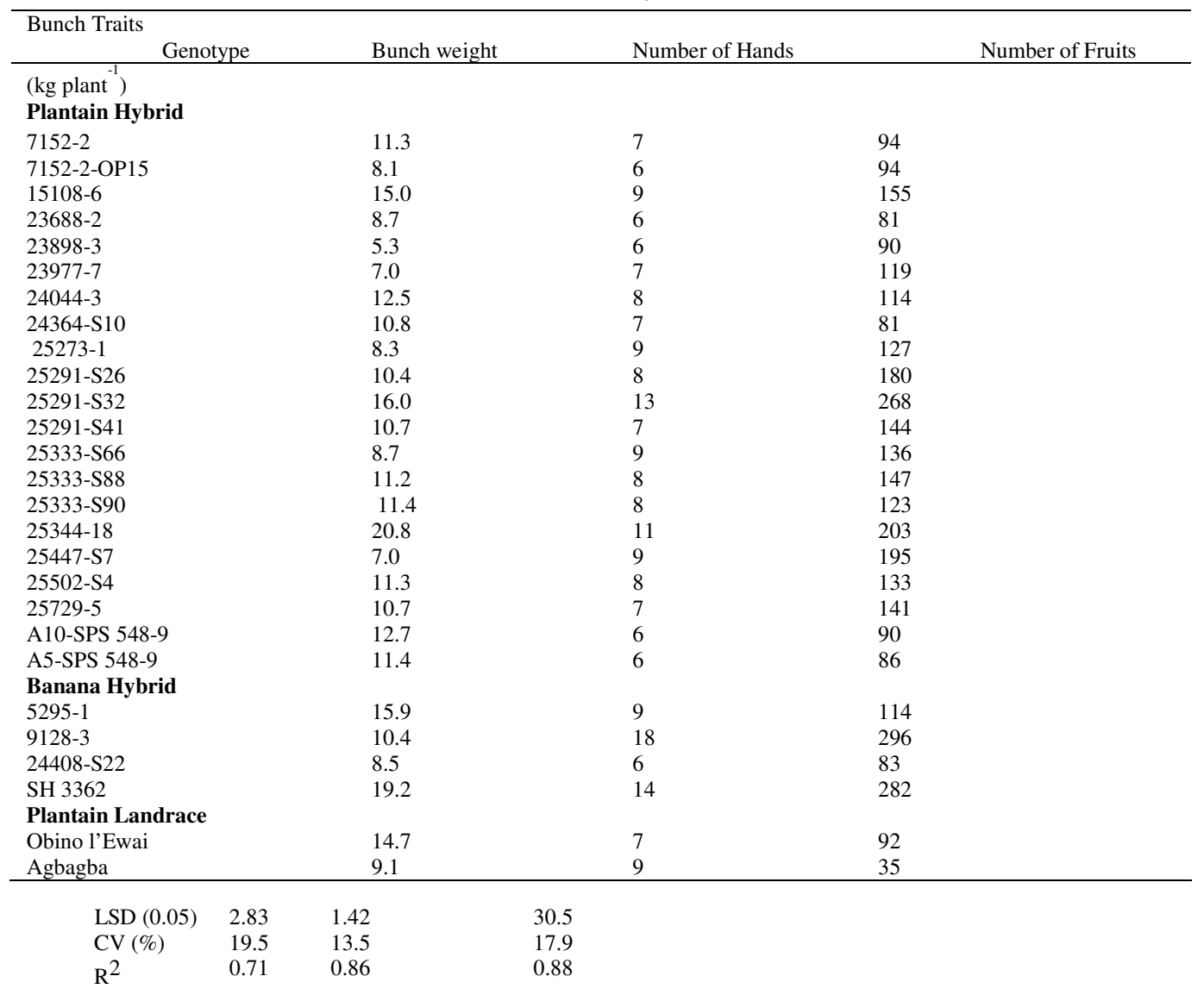

Table 2. Fruit dimensions in Musa spp. hybrid fruit at harvest.

\begin{tabular}{|c|c|c|c|}
\hline Genotype & & \multicolumn{2}{|l|}{ Fruit Traits } \\
\hline \multicolumn{4}{|c|}{ Plantain Hybrid } \\
\hline $7152-2$ & & 150.9 & 156.3 \\
\hline $15108-6$ & & 105.9 & 112.6 \\
\hline $23688-2$ & & 141.5 & 145.8 \\
\hline $23977-7$ & & 120.2 & 122.9 \\
\hline 25273-1 & & 88.5 & 91.5 \\
\hline 25291-S41 & & 98.5 & 102.0 \\
\hline 25333-S66 & & 102.0 & 106.0 \\
\hline 25333-S88 & & 106.5 & 109.4 \\
\hline 25447-S7 & & 67.5 & 72.9 \\
\hline 25502-S4 & & 100.8 & 102.5 \\
\hline $25729-5$ & & 126.5 & 130.2 \\
\hline A10-SPS 548-9 & & 201.8 & 205.9 \\
\hline \multicolumn{4}{|l|}{ Banana Hybrid } \\
\hline $5295-1$ & & 240.6 & 246.6 \\
\hline SH 3362 & & 100.7 & 102.3 \\
\hline \multicolumn{4}{|c|}{ Plantain Landrace } \\
\hline Obino l’Ewai & & 164.5 & 170.3 \\
\hline Agbagba & & 361.8 & 352.5 \\
\hline $\operatorname{LSD}(0.05)$ & 17.5 & 17.3 & \\
\hline $\mathrm{CV}(\%)$ & 12.4 & 12.1 & \\
\hline $\mathrm{R}^{2}$ & 0.95 & 0.94 & \\
\hline
\end{tabular}


Table 3. Correlation based on bunch weight and fruit traits for a selection of Musa hybrids at harvest.

\begin{tabular}{|c|c|c|c|c|}
\hline Bunch Traits $^{\mathrm{a}}$ & & & & \\
\hline BWT & $\mathrm{NH}$ & NF & FWT & FVOL \\
\hline BWT & $0.2480 * * *$ & $0.2731 * * *$ & $0.2268 *$ & $0.3067 * * *$ \\
\hline $\mathrm{NH}$ & & $0.8097 * * *$ & 0.0810 & 0.0763 \\
\hline NF & & & $-0.5720 * * *$ & $-0.5115^{* * *}$ \\
\hline FWT & & & & $0.9993 * * *$ \\
\hline FVOL & & & & - \\
\hline
\end{tabular}

\section{DISCUSSION}

Post harvest characteristics are essential in the screening of new plantain and banana hybrids, and also provide information that may complement delivery of new accessions to farmers. Plantain hybrid, 25344-18 was the top yielding genotype based on bunch weight among the twenty seven genotypes evaluated. Following the best performing hybrid 25344-18, was SH 3362, a banana hybrid in terms of yield, suggesting the potential for discriminating different Musa hybrids by their yield status where high yielding cultivars may form the basis of adoption and good marketing potential. The top yielding hybrid, 25344-18, was considerably better than its parents (7152-2 and 9128-3) and other hybrids and plantain landraces, which is attributed mainly to heterosis and black Sigatoka disease resistant trait in the new hybrid. This result is in consonance with earlier studies (Ortiz and Vuylsteke, 1996), which showed that some Musa hybrids outperformed their parents in terms of yield. Higher number of hand bunch ${ }^{1}$ exhibited by $25344-18$ coupled with high yield, may be probably linked to heterosis and disease resistance phenomenon, and are clearly very advantageous for new hybrids delivery process. From the results, clone 9128-3 was the best in terms of number of hand bunch- ${ }^{1}$ and number of fruit bunch $^{-1}$, and these traits were apparently retained by plantain hybrid 25344-18, a progeny of 9128-3. The plantain landrace, Agbagba differed significantly $(\mathrm{P}<0.05)$ from other genotypes both in fruit weight and fruit volume. There was a high significant difference $(\mathrm{P}<0.05)$ in fruit weight and fruit volume between banana hybrid, 5295-1 and all other hybrids as well as French plantain landrace, Obino l'Ewai. Highly significant positive correlation $(\mathrm{P}<0.01)$ was observed between bunch weight and the number of hands, number of fruits bunch $^{-1}$, as well as fruit volume. The same trend was observed in the number of hands bunch ${ }^{-1}$ and number of fruit hand ${ }^{-1}$, and between fruit weight and fruit volume. A high negative correlation $(\mathrm{P}<0.01)$ was also observed between number of fruit and fruit weight and volume. However, there was no correlation between number of hand and fruit weight, and number of hand and fruit volume.
Bunch and fruit traits are important because most producers and consumers of plantain and banana usually prefer large size bunch with large or small size fruits and/or long or short fruits, depending on locality or country (Dadzie and Orchard, 1997).

\section{CONCLUSION}

The new plantain hybrid (25344-18) and banana hybrid (SH 3362) with bunch $20.8 \mathrm{Kg}$ plant $^{1}$ and $19.2 \mathrm{Kg}$ plant $^{1}$ respectively, are strongly recommended for adoption based on their bunch weight. The number of hands and fruits bunch ${ }^{1}$ for 9128-3, SH 3362, 25291-S32 and 25344-18 were significantly different $(\mathrm{P}<0.05)$ from plantain landraces (Agbagba and Obino l'Ewai), suggesting better agronomic performance in the new hybrids. Hybrids 9128-3, SH 3362, 25291-S32 and 2534418 with higher number of hands and fruit bunch ${ }^{1}$ may therefore provide fresh fruits for domestic and export markets. The reference cultivar, Agbagba differed significantly $(\mathrm{P}<0.05)$ from the rest of the genotypes both in fruit weight and fruit volume, which provides the need for breeding and agronomic practices to bridge this gap.

\section{ACKNOWLEDGEMENT}

The first author gratefully acknowledge words of inspiration, technical assistance and encouragement from Prof. K.P. Baiyeri of the Department of Crop Science, University of Nigeria, Nsukka, Nigeria.

\section{REFERENCES}

Dadzie, B.K. and J.E. Orchard (1997). Routine Post Harvest Screening of Banana/Plantain Hybrids: Criteria and Methods. INIBAP Technical Guidelines 2. International Plant Genetic Resources Institute, Rome, Italy; International Network for the Improvement of Banana and Plantain, Montpellier, France; ACP-EU Technical Centre for Agricultural and rural Cooperation, Wageningen, The Netherlands. 
Adeniji, Tajudeen Adebayo, Barimalaa, Iminabo Samuel and Tenkouano, Abdou

FAO (1987). Production Yearbook 1986, Rome. Food and Agricultural Organisation of the United Nations.

Ferris, R.S.B., S. Akele, Y.O. Akalumhe and A. Ubi (1994). Distribution and acceptance of ABB cooking bananas in Southeast Nigeria. MusAfrica 5: 9-11.

Fullerton, R.A. (1994). Sigatoka leaf diseases. Pp. 1214 in Compendium of Tropical Fruit Diseases. (Ploetz, R.C. et al., eds). The American Phytopathological Society, St. Paul, Minnesota.

Hahn, S., D. Vuylsteke, and R. Swennen (1990). First reactions to $\mathrm{ABB}$ cooking bananas distributed in southeastern Nigeria. In: R.A. Fullerton and R.H. Stover (eds.). Sigatoka leaf spot diseases of bananas. Proceedings of an international workshop held at San Jose, Costa Rica, March 28April 1, 1989. INIBAP, Montpellier, France.

IITA (1988). IITA Annual Report and Research Highlights 1987/88. Ibadan Nigeria. International Institute of Tropical Agriculture, 161pp.

IITA (1992). Plantains and bananas. In: Sustainable food production in sub-Saharan Africa. International Institutte of Tropical Agriculture (IITA), Ibadan, Nigeria, p. 8691.

INIBAP (1987). Plantain in West and Central Africa. Proposal for Regional Research and Development Network. INIBAP/1987/9. Montpellier, France, International Network for the Improvement of Banana and Plantain.

IPGRI (1999). Annual Report 1998. International Plant Genetic Resources Institute, Rome.

Ortiz, R. and D. Vuylsteke (1996). Improving plantain-and banana- based systems. In: Ortiz, R. and Akoroda, M.O. (eds.). Plantain and Banana: production and
Research in West and Central Africa: Proceedings of a Regional Workshop, held at High Rainfall Station, Onne, Rivers State, Nigeria, Published by the International Institute of Tropical Agriculture (IITA), Ibadan, Nigeria, vii + $166 \mathrm{pp}$.

SAS Institute (1996). SAS Users Guide, Release 6.12 Edition, Statistical Analysis Systems Institute Inc. Cary, North Carolina, USA.

Stover, R. (1983). Effet du Cercospora noir sur les plantains en Amerique centrale. Fruits 38, 326-329.

Stover, R.H. and N.W. Simmonds (1987). Bananas. Tropical Agricultural Series. Third Edition. John Wiley \& Sons, Inc., 605 Third Avenue, New York, NY 10158, pp. 468.

Thompson, A.K. and O.J. Burden (1995). Harvesting and fruit care. In: S. Gowen (ed.). Bananas and Plantains. Chapman and Hall, London, UK, 612pp.

Vuylsteke, D., R. Ortiz, R.S.B. Ferris and J.H. Crouch (1997). Plantain Improvement. Plant Breeding Reviews, 14: 267-320. Jules Janick (ed.). John Wiley \& Sons, Inc. 
Agro-Science Journal of Tropical Agriculture, Food, Environment and Extension Volume 8 Number 2 Mav 2009 pp 121-129

ISSN 1119-7455

\title{
TILLAGE AND FERTILIZER EFFECT ON ROOT DISTRIBUTION, WATER UPTAKE AND YIELD OF MAIZE IN INLAND VALLEY SWAMPS IN SOUTHWESTERN NIGERIA
}

\author{
Ogban $^{1}$, P. I. and Babalola ${ }^{2}, O$ \\ ${ }^{1}$ Department of Soil Science, University of Uyo, Uyo, Nigeria \\ ${ }^{2}$ Department of Agronomy, University of Ibadan, Ibadan, Nigeria.
}

\begin{abstract}
Information on the hydraulic properties of a soil is important in understanding soil drainage, solute transport and water supply to plants, for improved agricultural production. Such information is, however, scarce for the wetlands in southwestern Nigeria. This study evaluated the effect of mound-tillage (MT), ridge-tillage $(R T)$, and no-tillage $(N T)$, with fertilizer $(F)$ and without fertilizer (Fo) on root growth, water extraction and yield of maize in three representative inland valley swamps, namely, very poorly drained (AY11L), poorly drained (AY13D), and imperfectly drained (AY22R) in the Ayepe area of Southwestern Nigeria. Root growth of maize was significantly $(P<0.05)$ increased by the application of fertilizer. The increases were greater in the $30 \mathrm{~cm}$ depth of the MT than $R T$ and $N T$ systems. Soil water storage $\left(\theta_{v}\right)$, root water extraction $\left(r_{z}\right)$ and total transpiration $\left(R_{z}\right)$ varied greatly among the tillage and fertilizer combinations, but generally higher in the mound-till with fertilizer than the ridge-till and no-till with fertilizer treatments in the 1989/90 dry season trial and higher in RT with fertilizer than RT without fertilizer in 1990/91 dry season trial. Green maize yield increased greatly in MT (3.89t/ha) compared with RT (2.77 t/ha) and NT (3.13 t/ha) in AY13D (poorly drained). Yields in AY22R (imperfectly drained) averaged 3.88 t/ha in MT, 2.73 t/ha in RT and 2.72 t/ha in NT. The moun -tillage system may be a more suitable soil and water management practice than the ridgetillage and no-tillage systems for increases in crop production in the wet inland valleys in southwestern Nigeria.
\end{abstract}

Keywords: Wet inland valley swamps, productive soils, tillage systems, crop production.

\section{INTRODUCTION}

Knowledge of the hydraulic properties of a soil is needed for any study of the status or movement of soil water and solutes, and in understanding water supply to plants in the field (Stone et al., 1973). The hydraulic properties required are the water content and conductivity characteristics, and relating soil water contents with matric potential and hydraulic conductivity, respectively. The water content in the root zone of a crop plant varies in both time and space, depending not only on soil factors but also on the ambient meteorological conditions and rooting characteristics of the crop, including density and depth of rooting. Generally, the amount of water available at any time for withdrawal by a plant increases with available soil water and with the volume of soil occupied by the roots.
Plant roots are not uniformly distributed in the soil; the shape and size of the root system differ greatly due to differences in the root environment (Taylor and Klepper, 1978). The root system is better developed in the upper layers of the soil than in the subsoil because of better aeration, nutrient supply and loose structure (Dugas et al., 1990; Klepper, 1990). Consequently, drainage that lowers the matric potential of soil water and a tillage system that loosens the soil, improve aeration, increase the rooting depth and thus enable roots to proliferate and penetrate unexploited zones (Taylor and Klepper, 1978). The works by Osuji (1984), Longsdon et al., (1987) and Rasmussen (1991) showed increased rooting with depth in tilled than in untilled soils, and that corn roots in the latter had larger diameter and were less efficient in water and nutrient uptake. Lal et al. (1989) reported that rootlength density was significantly higher in the 0-20 $\mathrm{cm}$ layer of tilled than untilled treatment, due to 
soil loosening which enhanced root proliferation in the former. Cornish (1987) attributed greater root growth in the top soil layer to the need for nutrient rather than water uptake. He also attributed greater root growth in the top layer of untilled soil to higher bulk density and often greater soil strength at lower depths. Drew and Saker (1978) had attributed that pattern of growth to the concentration of nutrients, either from native fertility or applied fertility in the surface layers.

The pattern of water depletion in the root zone depth depends on the rooting characteristics of the crop (the rate of transpiration and size, distribution and activity of the root system), and soil water matric potentials and hydraulic conductivity. Root density patterns may not necessarily, however, relate to root activity patterns, such as root water extraction. Equally, water extraction patterns may not necessarily be greater in the soil region with greater root-length density. Ehlers et al. (1980) and Willatt and Olson (1982) found water uptake rate functionally related to rooting density and soil water potential, and that relative growth rate decreased with decreasing soil water potential. Rose and Stern (1967) reported that maximum rate of water withdrawal was between the soil surface and $25 \mathrm{~cm}$ depth, and relatively low rate, below $30 \mathrm{~cm}$ while Rickman et al (1978), Willatt and Taylor (1978), and Sharp and Davies (1985) reported high uptake where root density was lowest. Reicosky et al. (1972) reported that in the presence of a water-table, water uptake was not necessarily related to root distribution in the profile and, that a small amount of roots near the capillary fringe absorbed most of the water.

Inland valley swamps are widespread in southwestern Nigeria. They are under the influence of a seasonal or perennially high groundwater table (Ogban and Babalola, 2002, 2003) and are cultivated in the dry season when the watertable will not adversely interfere with root growth and water extraction. The soils are potentially productive because of adequate water supply and long growing season, low lying topography and low erosion hazard. But the soils are little studied and underutilized. There is the need to characterize the soils for increases in agricultural production. This study was conducted to evaluate the effect of tillage and fertilizer on root distribution and water uptake, and yield of maize (Zea mays) in inland valley swamps in southwestern Nigeria.

\section{MATERIALS AND METHODS Experimental Site}

The study was conducted in three representative inland valley swamps (IVS) on the basis of watertable depth and soil taxonomic classification, namely, AYIIL (very poorly drained, Aquic Endoaquepts), AY13D (poorly drained, Typic Endoaquepts) and AY22R (imperfectly drained, Aeric Typic Endoaquepts) in the 1989/90 and 1990/91 dry season (December - March) in the Ayepe area of southwestern Nigeria. The area is located on latitude $7^{\circ} 20^{1} \mathrm{~N}$ and longitude $4^{\mathrm{o}} 15^{1} \mathrm{E}$. Annual rainfall averaged $1400 \mathrm{~mm}$ and temperature ranged from $24^{\circ} \mathrm{C}$ to $29^{\circ} \mathrm{C}$. Solar radiation averaged $382 \mathrm{~g} \mathrm{~cm}^{-2}$ day $^{-1}$ and total evaporation averaged 92 $\mathrm{mm} / \mathrm{month}$. The climate is divided into rainy (April-October) and dry (November-March) seasons. The soils are derived from the Basement Complex parent material and classified as Aquic Endoaquepts (AYIIL), Typic Endoaquepts (AY13D) and Aeric Typic Endoaquept (AY22R) (Ogban, 1999; Ogban and Babalola, 2009). Some physical and chemical properties of the soils are shown in Table 1.

\section{Field Methods}

There were two soil management practices, namely, tillage and fertilizer. Tillage consisted of mound-tillage (MT), ridge-tillage (RT), and no-tillage (NT) methods. The mounds were $45 \mathrm{~cm}$ high, $60 \mathrm{~cm}$ diameter and 12 rows of 14 mounds each. The ridges were of the same 45 $\mathrm{cm}$ high and $60 \mathrm{~cm}$ width, and 12 number rows. Both mounds and ridges were constructed with the short-handle hoe. The fertilizer treatment consisted of fertilized $(\mathrm{F})$ and unfertilized, control $\left(\mathrm{F}_{\mathrm{o}}\right)$. Each plot was $10.0 \mathrm{~m} \times 8.4 \mathrm{~m}$ and maize (TZESR-Y) seeds were sown at a spacing of $70 \mathrm{~cm} \times 70 \mathrm{~cm}$. The average distance between two adjacent rows of mounds/ridges and two mounds in a row was 70 $\mathrm{cm}$. The experiment was a split plot in randomized complete block (RCB) with three replications, with tillage in main plot and fertilizer in sub-plot, in $1989 / 90$ and 1990/91. The study was repeated in the 1990/91 planting season but with the ridge tillage system. Fertilizer application was based on soil test values of the nutrient elements, NPK (FMANR, 1990). The rates of application were 45 $\mathrm{kgN} / \mathrm{ha}, 2 \mathrm{kgP} / \mathrm{ha}$ and $16 \mathrm{kgK} / \mathrm{ha}$ in $\mathrm{AY} 11 \mathrm{~L}, 45$ $\mathrm{kgN} / \mathrm{ha}, 9 \mathrm{kgP} / \mathrm{ha}$ and $39 \mathrm{kgK} / \mathrm{ha}$ in AY13D, and 83 $\mathrm{kgN} / \mathrm{ha}, 18 \mathrm{kgP} / \mathrm{ha}$ and $31 \mathrm{kgK} / \mathrm{ha}$ in $\mathrm{AY} 22 \mathrm{R}$ at planting and a further $30 \mathrm{~kg}$ urea/ha at tasseling. In both seasons, all treatments were mulched at the rate of $4.2 \mathrm{t} / \mathrm{ha}$. The mulch consisted of plant residues collected at site. Weeds were controlled by slashing.

Soil samples were collected from each fertilizer treatment for laboratory physical and chemical analyses, using routine/conventional procedures (IITA, 1979; Page et al., 1982; Klute, 1986). Undisturbed core samples were collected at depth intervals $0-10,10-20$ and $20-30 \mathrm{~cm}$ with cylinders $7.2 \mathrm{~cm}$ long and $261.48 \mathrm{~cm}^{3}$ internal volume, for the determination of bulk density. Soil water content was determined regularly with the neutron probe at a depth of $20 \mathrm{~cm}$ in aluminum access tubes installed between two vigorously growing maize plants in each tillage treatment in 
$1989 / 90$ and in the ridge-tillage treatment in 1990/91. The hydraulic potential of soil water was measured with vacuum gauge tensiometers. The root zone of the soil profiles in this study are easily affected by water from the water table or capillarity, so that sorption of soil water by the tensiometer is possible, and may give erroneous readings of hydraulic head. This aspect of the study was to test the practicability of using the tensiometer in the soils. The tensiometers were installed so that the middle of the cups was at the $20 \mathrm{~cm}$ depth. The tensiometers were placed close to the access tube within the crop row in each fertilized and control plots of the mound, ridge and no-tillage systems in AY13D in 1989/90, and in the ridge-tillage system in AY11L, AY13D and AY22R in 1990/91. Measurements were limited to the $20 \mathrm{~cm}$ depth because of shallow watertables. Data on hydraulic head potential were collected at tasseling during four consecutive weeks in 1989/90, and six consecutive weeks in 1990/91. From the measurements of soil water content and hydraulic head potential, it was possible to calculate the potential gradients and soil water fluxes operating within the $20 \mathrm{~cm}$ soil layer and hence the unsaturated hydraulic conductivity values. The data obtained were applied to the analysis of root extraction or water uptake in the vegetated field as follows:

At any given time, the amount of water content along the depth interval between the soil surface and $20 \mathrm{~cm}$ was assumed to be identical to that measured with the neutron probe at $20 \mathrm{~cm}$, since this measurement covers a sphere of radius about $15 \mathrm{~cm}$. The amount of water stored in the 0 to 20 layer was obtained by integrating the water content $\left(\mathrm{cm}^{3}\right.$ of water per $\mathrm{cm}^{3}$ of soil) over the soil layer (Bababola, 1981). The extraction of water by plant roots, the temporal change in water storage with time and the cumulative root extraction or total transpiration were determined according to Ogata et al (1960), Rose and Stern (1967), Van Bavel et al. (1968) and Scott (2000). The waterfree pore space was obtained from the equation by Mbagwu (1983).

Duplicate root samples were collected at harvest from each fertilized and control plot of the tillage treatments, with core cylinders at depth increments of $7.2-\mathrm{cm}$ to a $36-\mathrm{cm}$ profile (Bohm, 1972). Root extractions were carefully washed and preserved in 5\% formaldehyde. Root length was measured with the grid intersection method (Tennant, 1975), and total root length was computed from the equation.

$\begin{array}{ll}\mathrm{R} & =\quad \mathrm{NL}_{\mathrm{f}} \\ \text { Where: } & \\ \mathrm{R} & =\quad \text { total length of roots in }\end{array}$

the sample, $\mathrm{cm}$
$\mathrm{N}=$ number of intersections between roots and grid lines

$\mathrm{L}_{\mathrm{f}} \quad=\quad$ length factor, which depends on grid spacing, for the $1 \mathrm{~cm}$ grid spacing used, $1 \mathrm{~cm}=0.786$.

Root length was also expressed as rootlength density $\left(\mathrm{cm}\right.$ roots $/ \mathrm{cm}^{3}$ soil collected in the cylinder). Green maize was harvested at 79 days after planting (DAP) at about $70 \%$ water content in both seasons.

Data on bulk density, soil water content, water-free pore space, root length and green yield were subjected to the analysis of variance, using the Genstat V, Release 1.3 operating on IBM PC compact at the International Institute of Tropical Agriculture (IITA), Ibandan, Nigeria. The Least Significant Difference (LSD) was used in separating the means.

\section{RESULTS AND DISCUSSION}

Effect of Tillage on Bulk Density, Water Content and Water-Free Pore Space: Bulk density differed $(\mathrm{P}<0.01)$ among the tillage methods, the highest value of $1.15 \mathrm{~g} / \mathrm{cm}^{3}$ occurring in RT and the lowest value of $1.04 \mathrm{~g} / \mathrm{cm}^{3}$ in $\mathrm{MT}$, in all three sites and two cropping (1989/90 and 1990/91) (Figure 1). Equally, the tilled plot had significantly $(\mathrm{P}<0.01)$ lower bulk

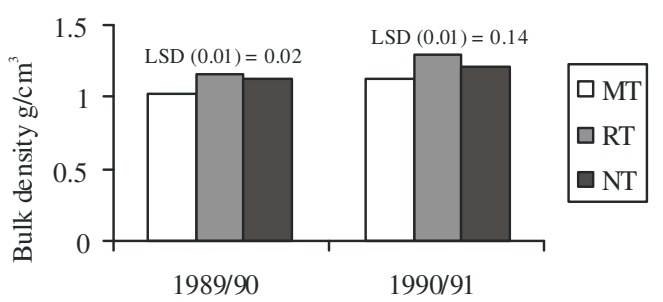

Figure 1: Effect of mounds (MT), ridges (RT) and no-till (NT) on bulk density in three inland valleys in 1989/90 and 1990/91 dry season

density, averaging $1.10 \mathrm{~g} / \mathrm{cm}^{3}$ than the $1.14 \mathrm{~g} / \mathrm{cm}^{3}$ recorded in the untilled, control plot. The lower bulk density value in the mounds indicated that tillage was probably more effective than the ridges. It was also probable that soil slumping or resettling was faster in the wetter ridges than the drier mounds. The results showed that tillage is needed in the soils, but that mounding (MT) may create a more favourable soil tilth (lower bulk density and soil strength) than ridging (RT). It could also be due to the finer texture of the surface soil. The low values of bulk density after two seasons of cropping, could be due to the fact that the soils are resilient, that is, they are inherently self-restorative (Kay, 1989; Lal, 1993), a quality often lacking in the adjacent well-drained upland soils when continuously, intensively cropped. Soil wetness may also have contributed to the observed low values of soil density. This is because water 
molecules may have formed wedges and reduced the cohesive forces between soil particles, thus loosening the soil and lowering soil density.

Table 1. Physical and chemical properties of the $30 \mathrm{~cm}$ top soil in the 1989/90* and $1990 / 91 * *$ Cropping seasons.

\begin{tabular}{|c|c|c|c|c|c|c|}
\hline Parameters & \multicolumn{2}{|c|}{ AY11L } & \multicolumn{2}{|c|}{ AY13D } & \multicolumn{2}{|c|}{ AY22R } \\
\hline Sand $\%$ & $45.5 *$ & $38.2 * *$ & 42.4 & 42.5 & 66.2 & 71.1 \\
\hline Silt $\%$ & 31.1 & 28.9 & 30.8 & 28.5 & 7.5 & 8.7 \\
\hline Clay $\%$ & 23.5 & 33.0 & 35.7 & 29.0 & 26.3 & 20.3 \\
\hline $\mathrm{pH}$ & 6.9 & 6.8 & 6.3 & 6.9 & 6.7 & 7.1 \\
\hline Org $\mathrm{C} \%$ & 1.1 & 2.03 & 2.78 & 2.14 & 0.37 & 2.01 \\
\hline Total N\% & 0.1 & 0.19 & 0.19 & 0.20 & 0.35 & 0.16 \\
\hline Av. P mg/kg & 13.47 & 6.37 & 10.48 & 5.77 & 4.98 & 6.00 \\
\hline $\mathrm{Ca} \mathrm{cmol} / \mathrm{kg}$ & 11.75 & 5.77 & 6.5 & 5.39 & 7.00 & 4.06 \\
\hline $\mathrm{Mg} \mathrm{cmol} / \mathrm{kg}$ & 3.44 & 1.67 & 3.05 & 1.74 & 3.61 & 1.67 \\
\hline $\mathrm{Na} \mathrm{cmol} / \mathrm{kg}$ & 0.50 & 0.80 & 0.52 & 0.70 & 0.64 & 0.71 \\
\hline $\mathrm{K} \mathrm{cmol} / \mathrm{kg}$ & 0.18 & 0.29 & 0.15 & 0.22 & 0.16 & 0.26 \\
\hline Ex. Ac. $\mathrm{cmol} / \mathrm{kg}$ & 0.20 & 0.11 & 0.20 & 0.09 & 0.20 & 0.09 \\
\hline $\mathrm{ECEC} \mathrm{cmol} / \mathrm{kg}$ & 45.15 & 8.59 & 10.42 & 7.99 & 11.6 & 6.73 \\
\hline $\mathrm{BS} \%$ & 98.6 & 98.6 & 98.1 & 98.9 & 97.8 & 98.5 \\
\hline
\end{tabular}

Table 2: Effect of mound-till (MT), ridgetill (RT) and no-till (NT) on (a) soil water content and (b) air-filled pore space in three inland valley bottoms in 1990/91 dry season

\begin{tabular}{lcl}
\hline MT & RT & NT \\
\hline 0.220 & 0.300 & 0.465 \\
(a) LSD $(0.01)=$ & $0.066 \mathrm{~cm}^{3} / \mathrm{cm}^{3}$ & \\
0.348 & 0.190 & 0.070 \\
(b) LSD $(0.01)=$ & $0.066 \mathrm{~cm}^{3} / \mathrm{cm}^{3}$ & \\
\hline
\end{tabular}

Seedbed preparation methods significantly $(\mathrm{P}<0.01)$ affected soil water retention in all three sites in 1990/91 (Table 2). The mean values were $0.378,0.355$ and $0.253 \mathrm{~cm}^{3} / \mathrm{cm}^{3}$, for AY11P, AY13D and AY22R, respectively. The effect was similar among the tillage methods in 1989/90. Soil water content (SWC) was highest in the control and lowest in MT, and also lower in tilled (averaging $0.260 \mathrm{~cm}^{3} / \mathrm{cm}^{3}$ ) than untilled (averaging 0.465 $\mathrm{cm}^{3} / \mathrm{cm}^{3}$ ) soil. The low SWC in the mounds was attributed to their discrete nature and greater evaporating surface, together with actively growing crop plants that aided the removal and thus decreasing the matric potential of soil water from the root zone of the wet soils, compared to the ridges and control (Hulugalle and Palada, 1990; Ogban and Babalola, 1999). The lower SWC in the tilled soil (averaging $0.260 \mathrm{~cm}^{3} / \mathrm{cm}^{3}$ ) supports the regulatory effect of tillage on soil drainage. However, the generally high values of SWC may have been due to the interacting effect of the shallow watertables, the fine textural range, and mulching and indicated that a favourable soil water balance may exist for dry season crop production in the wetland soils, and may explain the long growing season which occurs in the IVS.
Tillage also significantly $(\mathrm{P}<0.01)$ affected water-free pore space (WFPS) in 1990/91 (Table 2). The MT soil had an average air-space of $0.348 \mathrm{~cm}^{3} / \mathrm{cm}^{3}$, while RT had $0.190 \mathrm{~cm}^{3} / \mathrm{cm}^{3}$, and NT had $0.070 \mathrm{~cm}^{3} / \mathrm{cm}^{3}$.Air-space in the tilled soil was $84 \%$ greater than untilled soil. The MT was $22 \%$ greater than RT, and $97 \%$ greater than NT. Equally, RT was $91 \%$ greater than NT. Air-space in the tillage systems, tilled and untilled soil, followed the pattern of differences in SWC, although in the reverse direction. In particular, the sustained higher air-space in the mounds reflected their drier nature or lower matric potential, and may be more suitable soil in water management when compared with the ridges, and the no-tillage system, on the wet soils of IVS. The similarity between RT and NT systems in air-space and soil water content pointed to the need for caution in accepting the reports of Lal (1990) and Ohiri and Ezuma (1990) that soil conditions are better improved in the RT than NT system on poorly drained soils. However, except in the NT system, air-space was generally higher than the 0.10 $\mathrm{cm}^{3} / \mathrm{cm}^{3}$, often quoted in the literature as value for optimum root growth, and water and nutrient uptake functions in well-drained upland soils.

\section{Effect of Tillage and Fertilizer on Root Growth}

Tillage methods and fertilizer application significantly $(\mathrm{P}<0.05)$ increased the total root length of maize in the $30 \mathrm{~cm}$ soil depth in all three sites in 1989/90 (Figure 2). Fertilizer application 


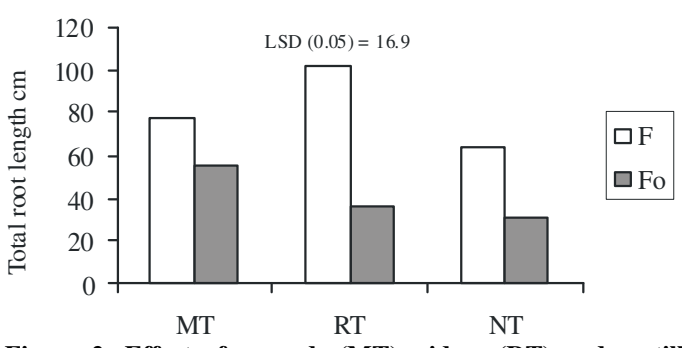

Figure 2: Effect of mounds (MT), ridges (RT) and no-till (NT), and fertilizer (F) and no fertilizer (Fo) interaction on total root length of maize in three inland valleys in 1989/90 dry season

significantly $(\mathrm{P}<0.05)$ increased root length in 1990/91 (Table 3). In both seasons, total root length was greater in MT than in RT and NT whether fertilizer was applied or not. The application of fertilizer however significantly $(\mathrm{P}<0.01)$ enhanced and increased root system development in the tilled than untilled soil.

Table 3: Effect of fertilizer (F) and no fertilizer on total root length of maize in three inland valley bottoms in 1990/91 dry season

\begin{tabular}{ll}
\hline $\mathrm{F}$ & Fo \\
\hline 138.0 & 109.7 \\
$\operatorname{LSD}(0.05)=25.7 \mathrm{~cm}$ & \\
\hline
\end{tabular}

Root-length density pattern (Figure 3) was similar to total root length.

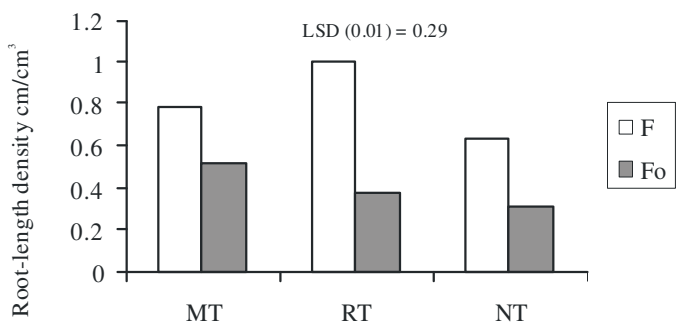

Figure 3: Effect of mounds (MT), ridges (RT) and no-till (NT), and fertilizer (F) and no fertilizer (Fo) interaction on root length density of maize in three inland valleys in $1989 / 90$ dry season

Root growth in the $0-15 \mathrm{~cm}$ soil layer was similar in the tilled soil, but significantly greater than the control. Root system development in 15 $30 \mathrm{~cm}$ soil depth was similar among the tilled and fertilizer methods. Total root length and root-length density decreased substantially below the $15 \mathrm{~cm}$ depth of both fertilized and control plots in 1989/90 and 1990/91.

Root growth was generally sparse and shallow. The observed pattern of root system development was attributed to the generally shallow ground-water tables (WT), averaging 70 $\mathrm{cm}$ in the sites. High WTs prevailed in 1989/90 and 1990/91. The high WTs may account for the observed sustained high values of SWC, unsaturated hydraulic conductivity and soil water flux density, which may have compensated the sparse rooting system. Consequently, extensive rooting was not necessary, as would in soils with deep WTs, where drought-stress could stimulate the proliferation and penetration of roots to compensate the slow rate at which water moves through soil to the roots (Hillel, 1971); in other words, water uptake depended on water movement to roots. The spare rooting system indicated that either all or few roots below the $15 \mathrm{~cm}$ soil depth extracted all the water needed to sustain the growth of the crop.

Effect of Tillage and Fertilizer on Hydraulic Properties and Root

Water Extraction

The amount of water stored as a depth equivalent $\left(\theta_{\mathrm{v}} \mathrm{cm} / \mathrm{cm}\right)$ in the $20 \mathrm{~cm}$ depth varied among the tillage and fertilizer treatment in AY13D in 1989/90 season (Figure 4). Root water extraction $\left(\mathrm{r}_{\mathrm{z}}\right.$ day $\left.^{-1}\right)$ (Figure 5) and cumulative transpiration (R,cm/day) (Figure 6) also varied among the treatments. However, values of the

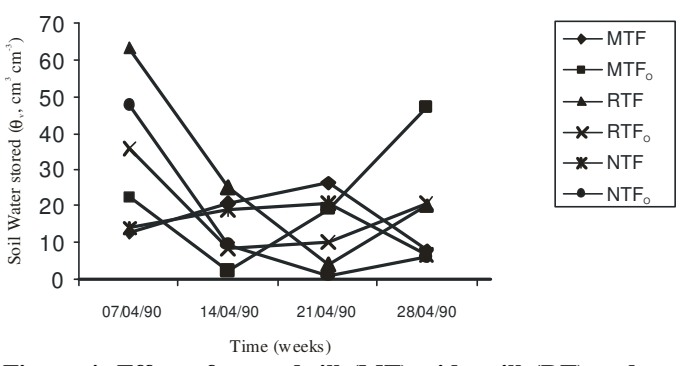

Figure 4: Effect of mound-till (MT), ridge-till (RT) and notill (NT) with and without (F0) fertilizer on Soil water stored (qv) in three inland valleys in the $1989 / 90$ trial.

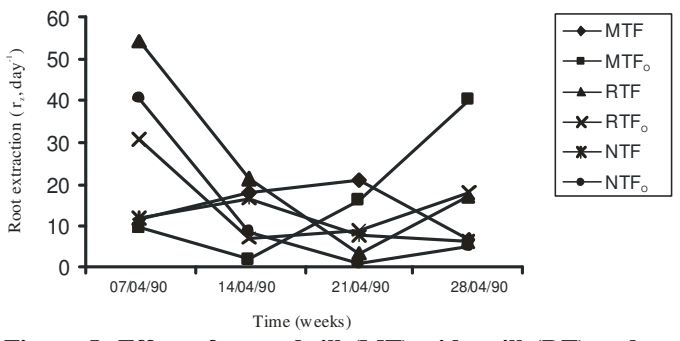

Figure 5: Effect of mound-till (MT), ridge-till (RT) and notill (NT) with and without (F0) fertilizer on root extraction $(\mathbf{r} 2)$ in three inland valleys in the $1989 / 90$ trial. 


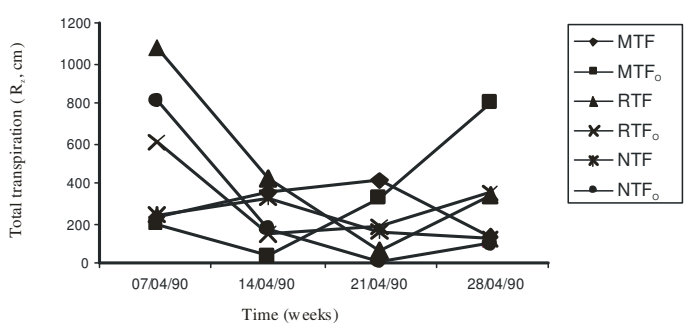

Figure 6: Effect of mound-till (MT), ridge-till (RT) and notill (NT) with and without (F0) fertilizer on total transpiration $(\mathrm{Rz})$ in three inland valleys in the 1989/90 trial.

parameters were generally higher in the mound-till than the ridge-till and no-till system, and in the fertilized than control plot in the 1989/90 season. Generally too, values of the parameters were higher initially, decreased till the third week and increased in the fourth week. Data of the hydraulic property (Figure 7) and root water extraction (Figures 8 and 9) also show a general pattern of higher values in the fertilized than control plot of the ridge-till with fertilizer than without fertilizer in 1990/91 trial. The amount of water stored and total transpiration increased to the highest value in the fourth week and declined greatly in the sixth week. This is probably because, as the dry season

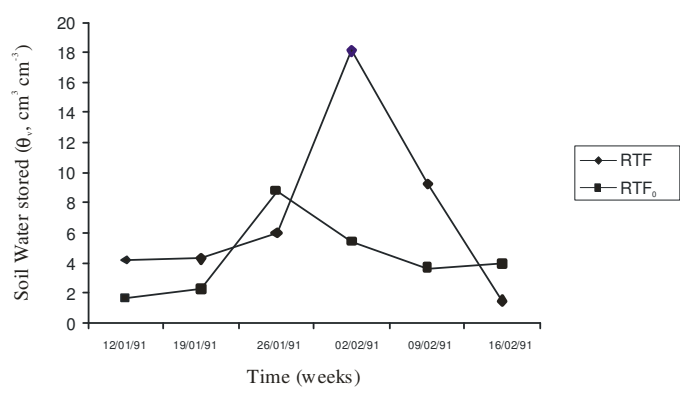

Figure 7: Effect of ridge-till (RT) with and without $(\mathrm{FO})$ fertilizer on Soil water stored (qv) in three inland valleys in the 1990/91 trial.

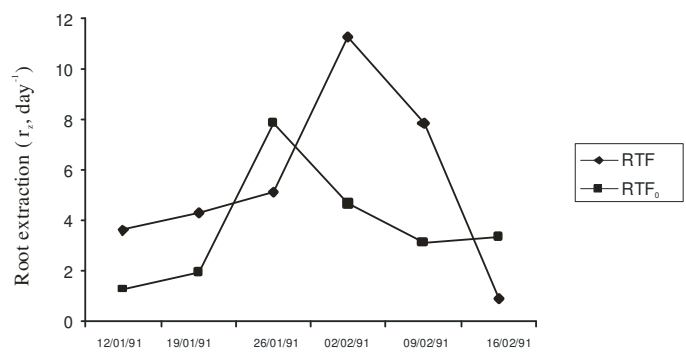

Figure 8: Effect of ridge-till (RT) with and without $(\mathrm{Fo})$ fertilizer on root extraction (rz) in three inland valleys in the 1990/91 trial.

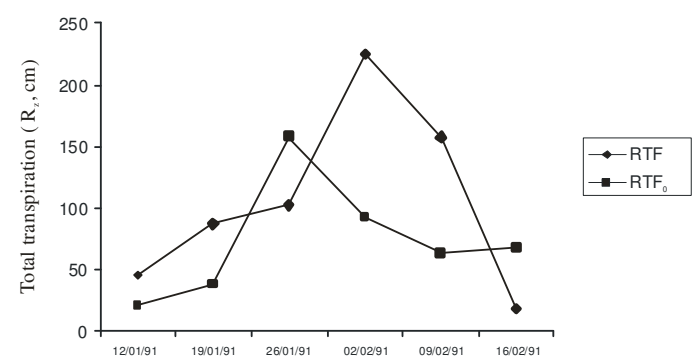

Figure 9: Effect of ridge-till (RT) with and without (F0) fertilizer on total transpiration $(\mathrm{Rz})$ in three inland valleys in the 1990/91 trial.

progressed the groundwater table receded rapidly to lower depths, limiting capillary rise and water infiltration into the rooting depth and therefore the amount of water extracted and transpired (during the peak of the dry season). This is important in terms of farming systems in the wetlands. It indicates that dryland farming in the wetlands must commence as the watertable recedes below the soil surface and soil strength improved so that crop roots could follow the receding groundwater table.

Analysis of plant height and root-length density indicated that there was significant effect of tillage and fertilizer on these plant activities. It is probable that the more vigorous plant activity in the fertilized plot caused soil water deficit, that is, negative matric potential or reduced hydraulic gradient in the surface layer, eliciting increased $\mathrm{dH} / \mathrm{dz}$ in the root zone, in response to evaporativity during the day. At night, when transpiration becomes negligible, the total soil water potential increased equalizing the water potential gradients which existed in the soil and plant during the previous day. The higher total soil water potential at lower depth caused water to flow towards the soil surface. Soil water storage increased until evaporativity resumed the following day. Changes in soil water storage may be small due to lack of vigorous plant activity.

The values of the parameters were generally high, indicating favourable soil characteristics that enhanced root activity in the soils. The variability in the values of the hydraulic properties and root absorption may indicate that no single factor among ground water supply, evaporativity and experimental treatments could be responsible for the observed differences. Equally, it may also point to the difficulty inherent in conducting this aspect of the study in soils with shallow water tables.

\section{Effect of Tillage and fertilizer on Green Maize Yield}

Tillage methods significantly $(\mathrm{P}<0.01)$ affected green cob yield in AY13D and AY22R, while yields in AY11L were similar (Figure 10) in 1989/90. In AY13D and AY22R, the yield from 
the MT plot was $1.12 \mathrm{t} / \mathrm{ha}$ or $40 \%$ and $0.76 \mathrm{t} / \mathrm{ha}$ or $24 \%$ greater than the yield from the RT and NT, respectively. Yields from RT and NT were similar, pointing to the fairly similar soil physical conditions in the two treatments. Fertilizer application had significant effect on the yield of maize (Table 4).

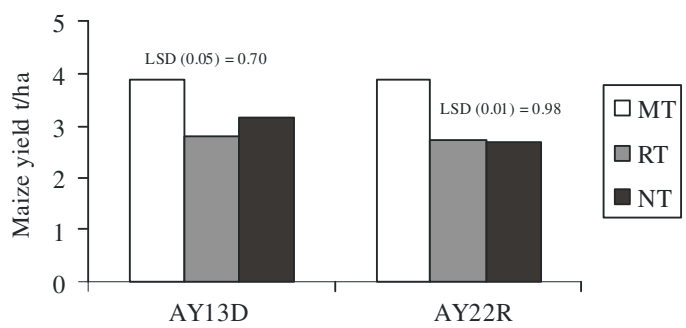

Figure 10. Effect of mounds (MT), ridges (RT) and no-till (NT) on green yield of maize in AY13D and AY22R inland valleys in 1989/90 dry season.

Table 4: Effect of fertilizer (F) and no fertilizer on green cob yield of maize in three inland valley bottoms in 1989/90 dry season

\begin{tabular}{ll}
\hline F & Fo \\
\hline 3.83 & 1.91 \\
$\operatorname{LSD}(0.01)=0.53 \mathrm{t} / \mathrm{ha}$ &
\end{tabular}

In 1990/91, the effect of tillage and fertilizer application was significant $(P<0.01)$ between MT and NT in AY22R (Figure 11). The yield from MT was $49 \%$ greater than NT. The yield increases from the tillage systems were largely due to fertilizer application, which were $60 \%$ more than the control.

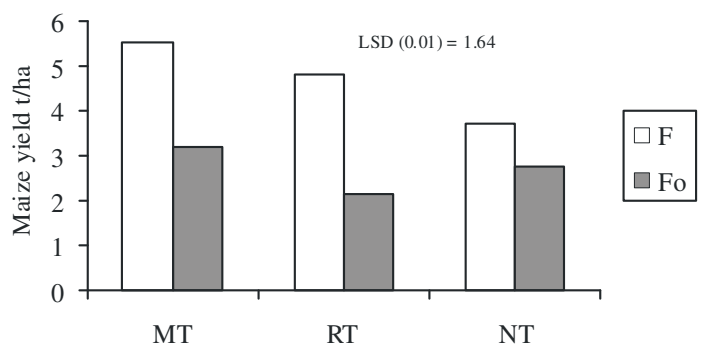

Figure 11. Effect of mounds (MT), ridges (RT) and no-till (NT), and fertilizer (F) and no fertilizer (Fo) interaction on green yield of maize in AY22R inland valley in 1990/91 dry season

The significant yield difference between MT and RT systems was attributed to the improved soil physical conditions (lower bulk density, higher aeration porosity) in the mounds compared with the ridges. The high yields obtained in the NT plot was attributed to improved aeration or low gaseous diffusion resistance, and root activity in the untilled soil. The consistently high yields obtained in the MT plot, with and without fertilizer, compared with yields from the RT plot, indicated that the mounds were the best suited in the hydromorphic soils. This is contrary to reports by Tarawali and MohamedSaleem (1987) on the usefulness of the ridge planting systems on poorly drained soils. The significant effect of the applied fertilizer indicates the need for nutrient supplementation (Lal and Taylor, 1989) for increases in crop production on these poorly drained soils. These increases can easily be obtained with mound-tillage, and therefore may be a more suitable soil and water management technology than ridge-tillage in the inland valley swamps.

\section{CONCLUSION}

Soils of the inland valleys in southwestern Nigeria on Basement Complex have excellent growing conditions, because of seasonal or perennially high groundwater table. The soils are cultivated by the low resource farmers, in the dry season when the watertable has receded below the root zone. This study demonstrated that the soils have high stored soil water or plant available water as well as root water uptake. Yields obtained were equally high, especially in fertilized mound-tillage than in ridge-tilled and no-tilled plots. The moundtilled system with fertilizer may be a more suitable soil and water management practice for increase in crop production in the inland valley wetland soils.

\section{ACKNOWLEDGEMENTS}

We thank the Ford Foundation of the USA for the funds and the International Institute of Tropical agriculture (IITA), Ibadan, Nigeria for the facilities used for the study.

\section{REFERENCES}

Bohm, W. 1979. Methods of studying Root Systems. Springer-Vertg, Berlin.

Cornish, P. S. 1987. Root growth and function in temperate pastures. In C. J. Pearson and G. E. Richards (eds) Temperate Pastures; Their Production, Use and Management. Pp 19-98.

Drew, M. C. and Saker, L. R. 1978. Effects of direct drilling and ploughing on root distribution in spring barley and on the concentration of extractable phosphate and potassium in the upper horizons of a clay soil. Sci. of Food Agric. 29: 201-207.

Dugas, W. A., Meyer, W. S. Barrs, H. D. and Flectwood, R. J. 1990. Effects of soil type on soybean crop water use in weighing lysimeters: Root growth, 
Tillage and Fertilizer Effects on Yield of Maize in Inland Valley Swamp.

soil water extraction and watertable contributions. Irrig. Sci. 11: 77-81.

Ehlers, W., Koshla, B. K., Kopke, U., Stulpnegel. R., Bohm, W. and Baeumer, K. 1980. Soil Tillage Res. 1;19-24.

FMANR (Fed. Min. Agric. Nat. Resource). 1990. Literature Review on Soil Fertility Investigation in Nigeria. FMANR, Lagos. 281p.

Hillel, D. 1971. Soil Water: Physical Principles and Processes. Acad. Press Inc. New York. 288p.

Hulugalle, N. R. and Palada, M. C. 1990. Effect of seedbed preparation method and mulch on soil physical properties and yield of cowpea in a rice fallow of an inland valley swamp. Soil Tillage Res. 17: 101-113.

IITA. 1979. Selected Methods for Soil and Plant Analysis. Int. Inst. Trop. Agric. (IITA), Ibadan, Nigeria. 79p.

Kay, B. D. 1998. Rates of changes in soil structure under different cropping systems. Adv. Soil. Sci. 12:1-52.

Klepper, B. 1990. Root growth and water uptake. In Irrigation of Agricultural Crops. Agron. Monogr. 30: 282 - 321

Klute A. 1986. Methods of Soil Analysis, No. 9, Part 1, Physical and Mineralogical Properties. Am Soc. Agron. Monogr. Madison, WI, USA. 1174p.

Lal, R. 1993. Tillage effect on soil degradation, soil resilience, soil quality and sustainability. Soil Tillage Res. $27: 1$ 8.

Lal, R., Logan, T. J. and Fausey, N. R. 1989. Longterm tillage and wheel traffic effects on poorly drained Mollic-Ochraquaf in Norh-West Ohio: Soil physical properties, root distrbution and grain yield of corn and soybean. Soil Tillage. Res. $14: 317-382$.

Longsdon, S. D., Reneasu Jr, R. B. and Parker, J. C. 1987. Crop-seedling root growth as influenced by soil properties. Agron. J. $79: 221-224$.

Mbagwu, J., Lal, R. and Scott, T. W. 1983. Physical properties of three soils in Southern Nigeria. Soil Sci. 136:48-55.

Ogata, G., Richards, L. A and Gardner, W. R. 1960. Transpiration of alfalfa determination from water content changes. Soil Sci. 89: 179 - 182.

Ogban, P. I. 1999. Characterization and Management of Inand Valley Swamps for Crop Production in Southwestern Nigeria. Ph.D Dissertation. Department of Agronomy, University of Ibadan, Ibadan, Nigeria. 326p.
Ogban, P. I. and Babalola, O. 1999. Preliminary evaluation of tillage systems on poorly - drained inland valley bottoms soils. Trop. Agric., 76 : $236-$ 240.

Ogban, P. I. and Babalola, O. 2002. Evaluation of drainage and tillage effect on watertable depth and maize yield in wet inland valleys in southwestern Nigeria. Agric. Water Management $52: 215-231$.

Ogban, P. I. and Babalola, O. 2003. Soil characteristics and constraints to crop production in inland valley bottoms in Southwestern Nigeria. Agric Water Management, $61: 13-28$

Ogban, P. I. and Babalola, O. 2009. Characterization, Classification and Management of Inland Valley Bottom Soils for Crop Production in Subhumid Southwestern Nigeria. AgroScience . 8:1-13.

Page, A. L. Miller, R. H. and Keeney, D. R. 1982. Methods of Soil Analysis, No. 9, Part 2, Chemical and Microbiological Properties. Am. Soc. Agron., Madison, WI, USA.

Rasmussen, K. J. 1991. Reduced soil tillage and Italian ryegrass as a catch-crop: soil bulk density, root development and soil chemistry. Tissler for Planteaul 95: $139-154$.

Reicosky, D. C., Millington, R. J. Klute, A. and Peters, D. B. 1972. Patterns of water uptake and root distribution of soybeans in the presence of a watertable. Agron. J. 64 : 292-297.

Ricksman, R. W., Allmaras, R. R. and Ranning, R. E. 1978. Root sink descriptions of water supply to dryland wheat. Agron. J. 70: 723-727.

Rose, C. W. and Stern, W. R. 1967. Determination of withdrawal of water from soil by corn roots as a function of depth and time. Aust. J. Soil Res. 5:11-19.

Scott, H. D. 2000. Soil Physics: Agricultural and Environmental Applications. Iowa State University Press, Ames, Iowa, USA. 421p.

Sharp, R. E. and Davis, W. J. 1985. Root growth and water uptake by maize plant in drying soil. J. Exp. Bot. 36 : 1441 1456.

Stone, L. R., Horton, M. I. and Olson, T. C. 1973. Water loss from an irrigated sorghum field: Water flux within and below the root zone. Agron. J. 65 : 492 - 497. 
Tarawali, G and Mohammed-Saleem, M. A. 1987. Effect of method of cultivation on root density and grain and crop residue yield of sorghum. Int. Livestock Centre for Africa (ILCA) Bull. No. 27 Addis Ababa, Ethopia.

Taylor, H. M. and Klepper. B. 1978. The role of rooting characteristic in the supply of water to plants. Adv. Agron. $30: 99-$ 128.

Tennant, D. 1975, A test of a modified line intersect method of estimating root length. J. Ecol. 63 : 995 - 1001.

van Bavel, C. H. M., Stirk, G. B. and Brust, K. J. 1968. Hydraulic properties of a clay loam soil and field measurement of water uptake by roots: Interpretation of water content and pressure profiles. Soil Sci. Soc. Am. Proc. 32 : $310-$ 317.

Willatt, S. T. and Taylor, H. M. 1978. Water uptake by soybean roots as affected by their depth and soil water content. J. Agric. Sci. $90: 205-211$.

Willatt, S. T. and Olson, K. A. 1982. Root distribution and water uptake by irrigated soybeans on a duplex soil. Aust. J. Soil Res. 20 : 139 - 146. 
Agro-Science Journal of Tropical Agriculture, Food, Environment and Extension Volume 8 Number 2 Mav 2009 pp 130-138

ISSN 1119-7455

\title{
IMPLICATIONS OF POLYEMBRYONY ON THE GROWTH AND YIELD OF FLUTED PUMPKIN (Telfairia occidentalis HOOK. F.)
}

\author{
Onovo ${ }^{1}$ J. C. Uguru' ${ }^{2}$ M. I. and $\mathrm{Obi}^{3}$ I.U. \\ ${ }^{1}$ Department of Biological Sciences, Nasarawa State University, Keffi, \\ Nasarawa State, Nigeria. E-mail: onovojos@yahoo.com \\ ${ }^{2}$ Department of Crop Science, University of Nigeria, Nsukka, Nigeria. \\ ${ }^{3}$ Department of Crop Science, University of Nigeria, Nsukka, Nigeria.
}

\begin{abstract}
Two experiments were conducted during the wet seasons of 2004 and 2005 to investigate the performance of polyembryonic lines with respect to growth and yield of fluted pumpkin. The results revealed three morphotypes of polyembryony, namely: twin (bi-embryony), triple (tri-embryony) and quadruple (tetra-embryony). In the first year (2004), the triple and quadruple embryo types had the highest (54.52\%) and lowest (2.02\%) frequencies of occurrence, respectively. In the second year (2005), the frequencies of the triple and quadruple embryo types were 60.99\% and $4.78 \%$, respectively. There was no clear trend across all the embryo types investigated with respect to the characters measured. However, generally, the triple and the single (mono-embryony) lines performed better than the twin and quadruple lines. The impressive performance of the single and triple embryo types over the twin and quadruple embryo types with respect to the weight of pods, in 2004 and 2005 suggests that these embryo types are good candidates multiplication and distribution to farmers using the micropropagation technique.
\end{abstract}

Key words: Polyembryony, growth, yield, fluted pumpkin, Telfairia occidentalis.

\section{INTRODUCTION}

The fluted pumpkin (Telfairia occidentalis Hook. F.) belongs to the family cucurbitaceae, which consists of 90 genera and 750 species (Irvine,1969; Purseglove, 1984). It is one of the most widely cultivated leafy vegetables in southern Nigeria (Odiaka et al., 2008). Asiegbu (1987) reported protein and oil contents of the seed at 30.1 and $47 \%$, respectively. He also reported that the essential amino acid content compared favourably with those of important legumes such as soybean and groundnut. The plant could also find potential use in medicine since the roots and older leaf extract contain compounds such as resins, alkaloids and saponins (Akubue et al., 1980). It could also be exploited as a cover crop along with melon (Colocynthis vulgaris) in vegetable farms of Okra (Abelmoschus esculentus) and Pepper (Capsicum annum) (Akobundu, 1987).

One characteristic feature of fluted pumpkin is its exhibition of the polyembryonic trait. Different forms of polyembryony have been reported to occur in T.occidentalis
(Odiyi, 2003). The author suggested that the occurrence of polyembryony is natural and that multiple seedlings were observed to develop in two areas of the seeds of the crop. The occurrence of multiple embryos in the embryonic axis and cotyledons makes it possible to obtain more plants from one seed as suggested by Esiaba (1982). This may help to overcome shortage of planting materials However, the seedlings are likely to be similar in all respects because of the post-zygotic and post-germinal nature of the emerging embryos (Odiyi, 2003). In addition, seedlings emerging from the cotyledons can serve as substitutes where zygotic embryos or seedlings are poorly developed or damaged during germination. Guo et al. (2006) reported that polyembryony and male/female sterility are two reproductive difficulties that have greatly hampered the improvement of Citrus by conventional sexual breeding. Sedgely and Griffing (1989) reported that polyembryony is under genetic control in some fruit tree crops. For instance, in Irvingia gabonensis, the level of polyembryony was 
found to differ among accessions collected worldwide. Accessions that showed polyembryony in Ibadan also showed high levels of polyembryony in M'Balmayo, Onne and Ibadan, indicating that it is probably an inherited characteristic in the accessions exhibiting this trait. Assessment of six kernels from a polyembryonic fruit was about equivalent to the weight of the single kernel of normal fruit from the same accession. Therefore, from a production point of view, there seems to be little reason to select for this characteristic.

The occurrence of multiple seedlings has led to questions as to the type, frequency, benefits and morphotypes of such a trait. The present research was initiated to investigate the forms and benefits or otherwise of the polyembryonic lines through their performance in the field, and provide useful information to farmers who grow fluted pumpkin.

\section{MATERIALS AND METHODS}

The experiments were conducted at the laboratory and research farms of the Department of Crop Science, Faculty of Agriculture, University of Nigeria, Nsukka. Nsukka is located at Latitude $6{ }^{0} 52^{1} \mathrm{~N}$, Longitude $7^{0} 24^{1} \mathrm{E}$, and on Altitude of $447.2 \mathrm{~m}$, in the derived guinea savanna region of Nigeria. Twenty eight fluted pumpkin pods were collected from the research farm of the University of Nigeria, Nsukka, at the end of the growing season in 2003 and carefully preserved. At the beginning of the rainy season in 2004, the pods were split open and the seeds extracted and cleaned of the perispermic tissues. The seeds were pre-sprouted in a nursery medium consisting of well cured softwood sawdust. Watering was done on daily basis until the seeds started to sprout.

As soon as the cotyledons split open, the seeds were removed from the medium and their cotyledons were carefully examined with a hand lens for the number of emerging embryos. The seedlings of each of the four embryonic types observed (i.e. single, twin, triple and quadruple) were replanted in separate nursery boxes. The seedlings were transplanted at two weeks after planting.

The experimental design was a Randomized Complete Block Design (RCBD) with three replications. The single (monoembryony), twin, triple and quadruple embryos constituted the four (4) treatments. A portion of land measuring $83 \mathrm{~m}$ x $24 \mathrm{~m}\left(1992 \mathrm{~m}^{2}\right)$ was slashed, ploughed, harrowed and marked out into three blocks. Each block was divided into four (4) plots. A foot path was allowed between blocks.

A total of 1,836 pre-sprouted seedlings from the 28 pods were planted at a spacing of $1 \mathrm{~m} \times 1 \mathrm{~m}$. Each of the four plots consisted of 80,120, 250 and 9 seedlings of single, twin, triple and quadruple embryo types, respectively. Plots were labelled accordingly following random treatment allocation for ease of identification of the treatments. N-P-K, 15: 15: 15 fertilizer at the rate of $300 \mathrm{~kg} \mathrm{ha}^{-1}$ was applied four weeks after planting, according to Akoroda (1990). Weeding operation was carried out regularly as required. At the beginning of the rainy season in 2005, fresh seedlings from the seeds of the 2004 harvest were examined and the distribution of the different embryonic types were recorded. Numerical counts were made for the different embryonic forms and the number of the embryo types in the populations of fluted pumpkin were recorded. Similar experimental design, fertilizer application and cultural practices done in 2004 were carried out in 2005 , using a total of 1,151 pre-sprouted seedlings. Each of the four plots consisted of 37, 61, 176 and 14 seedlings of single, twin, triple and quadruple embryo types, respectively.

Data on number of leaves at 4 and 8 weeks after planting, length of longest vine at 4 and 8 weeks after planting, number of branches at 4 and 8 weeks after planting, and fresh weight of pods per treatment at maturity of the different embryonic types were collected. The field data were subjected to analysis of variance according to Steel and Torrie (1980). The separation of treatment means for statistical significance was done using F-LSD according to Obi (1986).

\section{RESULTS}

Polyembryony in Telfairia occidentalis was expressed in three forms, namely twin, triple and quadruple. Plate 1 shows mono-embryony (1A) and the three morphotypes of polyembryony (1B, C and D). The results of the frequencies of the single and polyembryonic embryo types in 2004 and 2005 are presented in Table 1. The triple and the quadruple embryo types had the highest $(54.52 \%)$ and lowest $(2.02 \%)$ frequencies of occurrence, respectively. Similar results were obtained 
Table 1: Frequencies of the single and polyembryonic embryo types in 2004 and 2005.

\begin{tabular}{|c|c|c|c|c|c|c|c|c|c|}
\hline Embryo type & \multicolumn{2}{|l|}{$\mathbf{S}$} & \multicolumn{2}{|l|}{ Tw } & \multicolumn{2}{|l|}{$\mathbf{T r}$} & \multicolumn{2}{|l|}{$\mathbf{Q}$} & \multirow[t]{2}{*}{ Total } \\
\hline & No & $\begin{array}{l}\mathrm{F}( \\
\%)\end{array}$ & No. & $\begin{array}{l}\mathrm{F}( \\
\%)\end{array}$ & No. & $\begin{array}{l}\mathrm{F}( \\
\%)\end{array}$ & No. & $\begin{array}{l}\mathrm{F}( \\
\%)\end{array}$ & \\
\hline Year & & & & & & & & & \\
\hline$\overline{2004}$ & 319 & 17.37 & 479 & 26.09 & 1001 & 54.52 & 37 & 2.02 & 1836 \\
\hline 2005 & 150 & 13.03 & 244 & 21.20 & 702 & 60.99 & 55 & 4.78 & 1151 \\
\hline $\begin{array}{lll}\mathbf{S}- & \text { Single } \\
\mathbf{T w}- & \text { Twin } \\
\mathbf{T r}- & \text { Triple } \\
\mathbf{Q}- & \text { Quadr }\end{array}$ & $\begin{array}{l}\text { yo ty } \\
\text { yo ty } \\
\text { yo ty } \\
\text { embr }\end{array}$ & type & & & & & & & \\
\hline
\end{tabular}

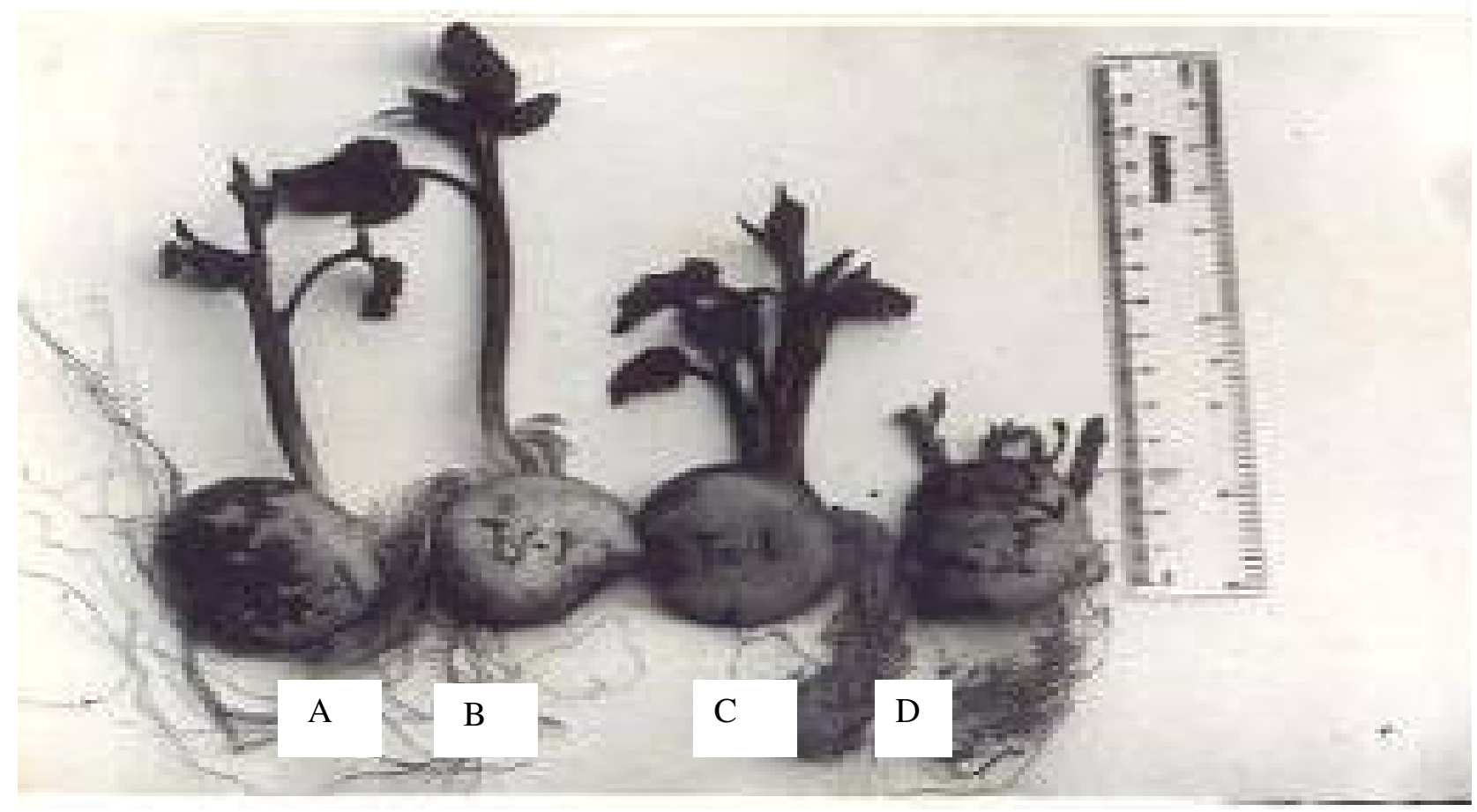

Plate 1. Single and three morphotypes of polyembryony: A (Single), B (Twin), C (Triple) and D (Quadruple

in 2005 with the triple type giving $60.99 \%$ and quadruple $4.78 \%$.

The results of the effect of embryo type on number of leaves at 4 weeks after planting (WAP) for 2004 and 2005 are presented in Fig. 1. The results revealed that the embryo types performed better in 2005 than in 2004 with respect to number of leaves. In 2004, single, triple and quadruple were comparable and differed significantly $(\mathrm{P}<0.05)$ from twin which produced lower number of leaves. In 2005, single and twin were comparable and differed significantly $(\mathrm{P}<0.05)$ from triple and quadruple.
At 8 WAP in 2004, single embryony produced significantly higher number of leaves (Fig. 2). As the number of embryos increased, there was a concomitant reduction in the number of leaves. However in 2005, though twin produced lower number of leaves at 8WAP than the other embryo types, the trend appears to be the reverse of the result obtained in 2004, hence, there was a concomitant increase in the number of leaves as the number of embryos increased at 8 WAP.

Figure 3 shows the effect of embryo type on vine length at 4WAP in 2004 and 2005. In 2004, twin and triple 
were comparable but were significantly ( $\mathrm{P}$ $<0.05)$ lower than single and quadruple which produced longer vines. In 2005, single, twin and triple had comparable values, and they differed significantly $(\mathrm{P}<$ $0.05)$ from the quadruple which had the highest value of vine length. At 8 WAP in 2004 (Fig. 4), twin and triple were comparable and differed significantly $(\mathrm{P}<$ 0.05) from single and quadruple which had the highest and lowest values, respectively. In 2005, single and triple were comparable and differed significantly $(\mathrm{P}<0.05)$ from twin and quadruple which had comparable but higher values of vine length.

The results of the effect of embryo type on the number of branches at 4 and 8WAP are presented in Figs. 5 and 6, respectively. In 2004 at 4WAP, single and twin had equal mean number of branches that differed significantly $(\mathrm{P}<0.05)$ from the number of branches of triple and quadruple which also had equal number of branches. However, in 2005, all the embryo types performed better with respect to the number of branches than in 2004, although, single, twin and triple had comparable values that differed significantly $(\mathrm{P}<0.05)$ from quadruple which had the highest number of branches. The results obtained at 8WAP showed a consistent decrease in vine length with increase in the number of embryos in 2004. However, in 2005, all the embryo types differed significantly from one another with respect to mean number of branches at $8 \mathrm{WAP}$.

Figure 7 shows the mean weight of pods per plant of the embryo types in 2004 and 2005. In 2004, single and triple were comparable and performed better than twin and quadruple. They also differed significantly $(\mathrm{P}<0.05)$ from twin and quadruple. In 2005, similar results were obtained with respect to weight of pods per plant.

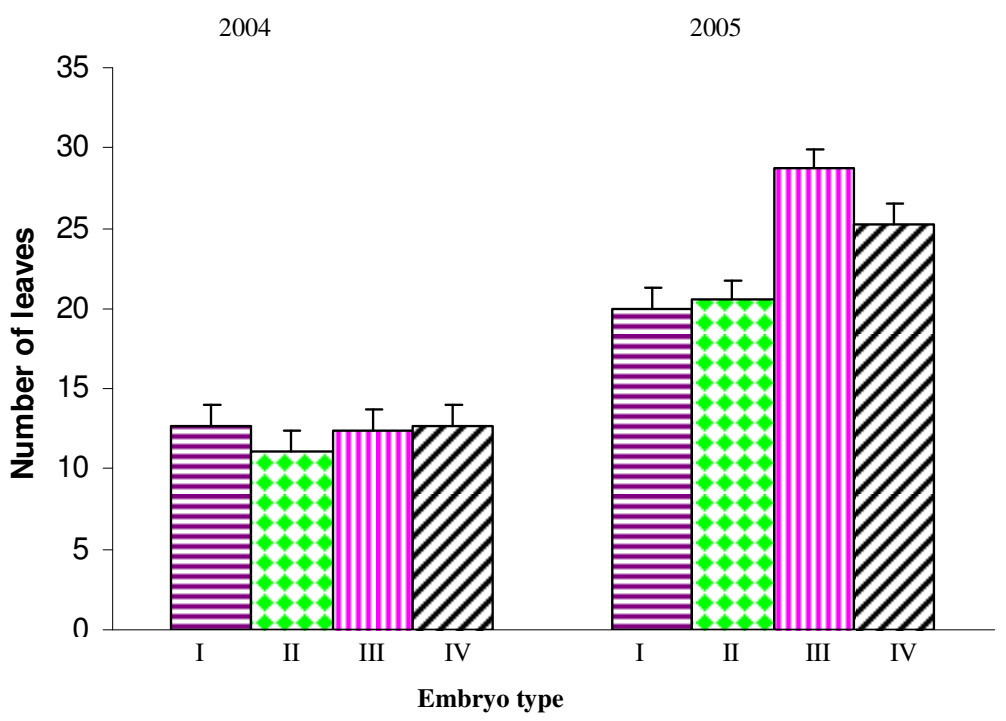

日 I.Single embryo $\square$ II. Twin embryo ๑ III.Triple embryo 口 IV.Quadruple embryo

Fig 1:Effect of embryo type on number of leaves at 4 WAP in 2004 and 2005 


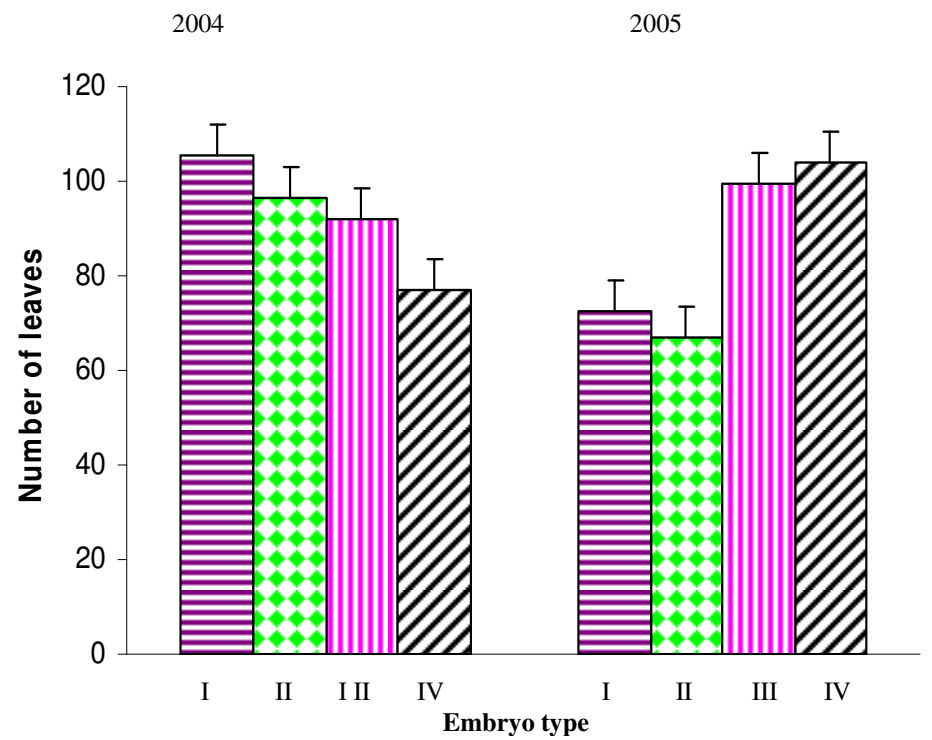

曰 I.Single embryo

$\checkmark$ Il. Twin embryo

๑ III.Triple embryo

$\checkmark$ IV.Quadruple embryo

Fig 2:Effect of embryo type on number of leaves at 8 WAP in 2004 and 2005

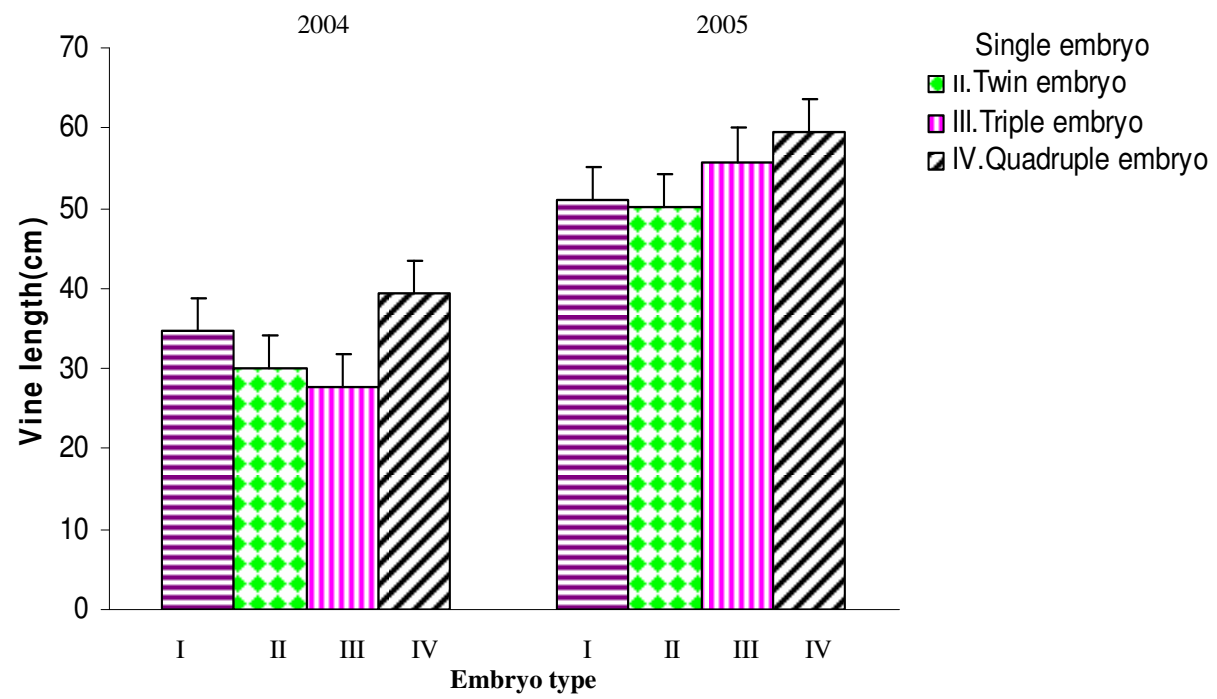

Fig. 3:Effect of embryo type on vine length at 4 WAP in 2004 and 2005 


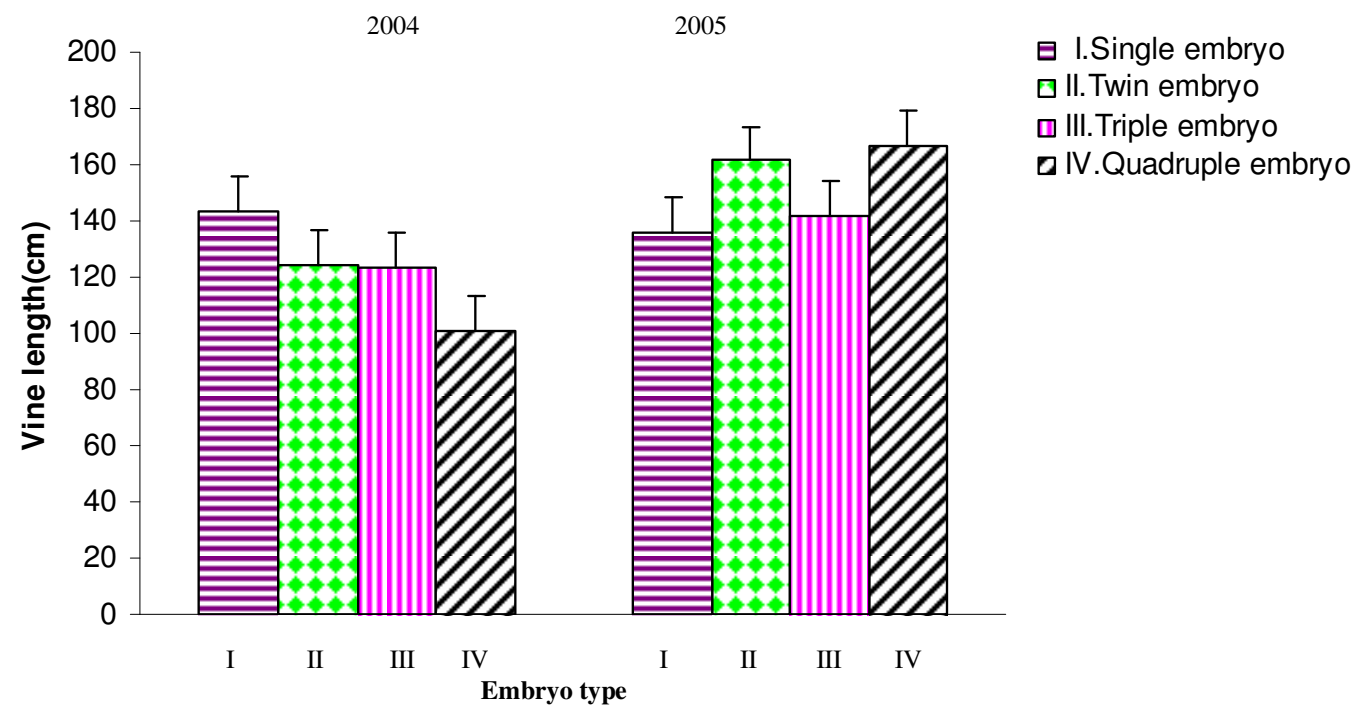

Fig 4:Effect of embryo type on vine length at 8 WAP in 2004 and 2005

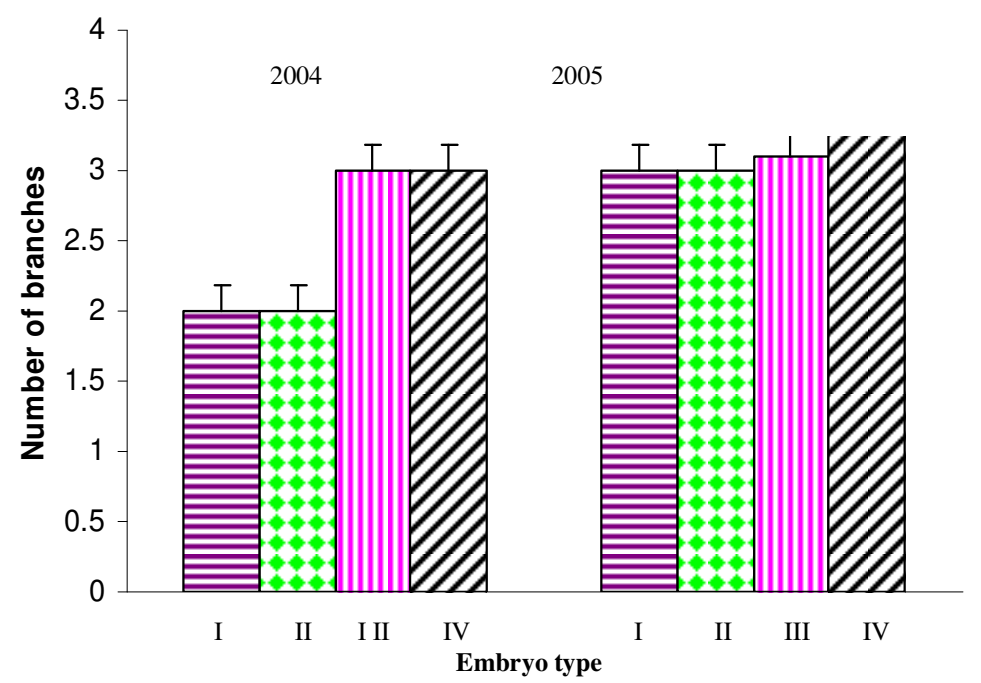

日 I.Single embryo
$\square$ II.Twin embryo
$\square$ III.Triple embryo
$\square$ IV.Quadruple embryo

Fig 5:Effect of embryo type on number of branches at 4 WAP in 2004 and 2005 
Onovo J. C. Uguru M. I. and Obi I..U.

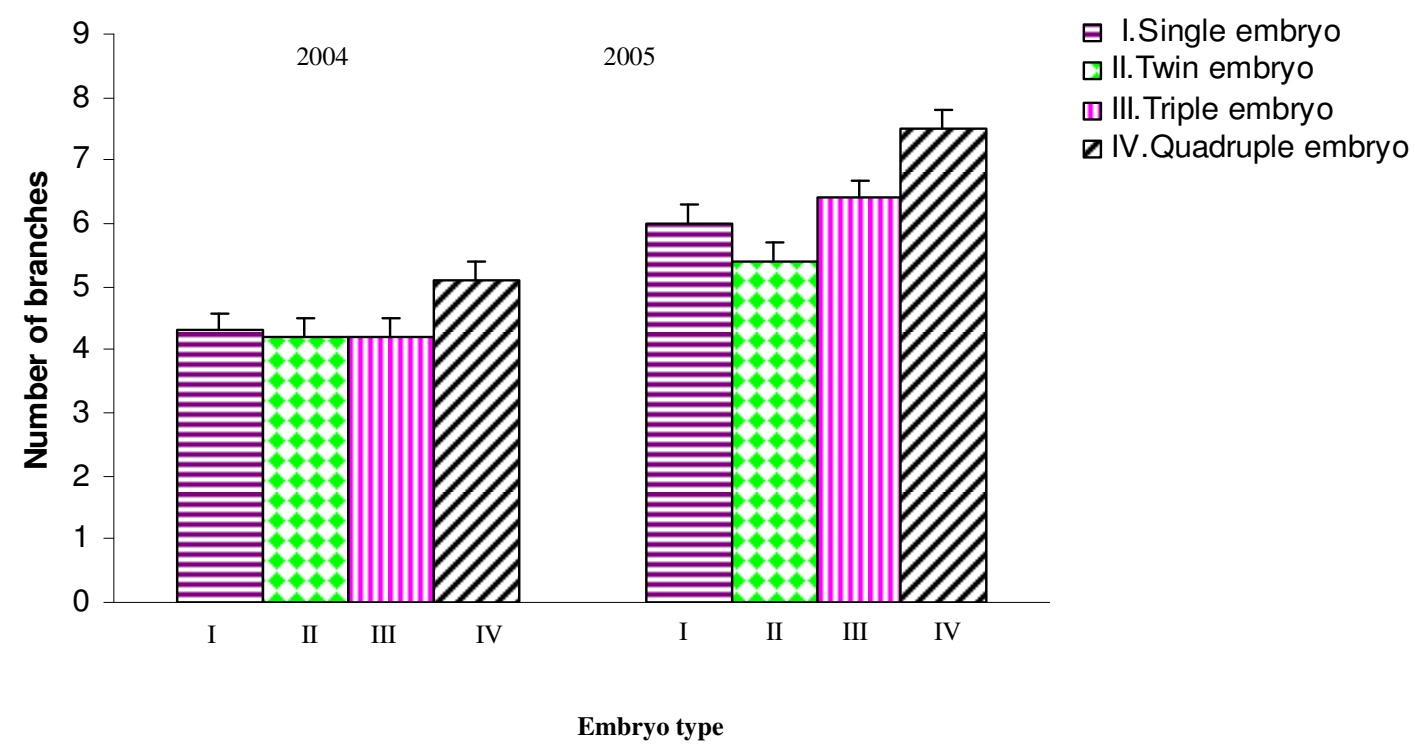

Fig 6:Effect of embryo type on number of branches at 8 WAP in 2004 and 2005

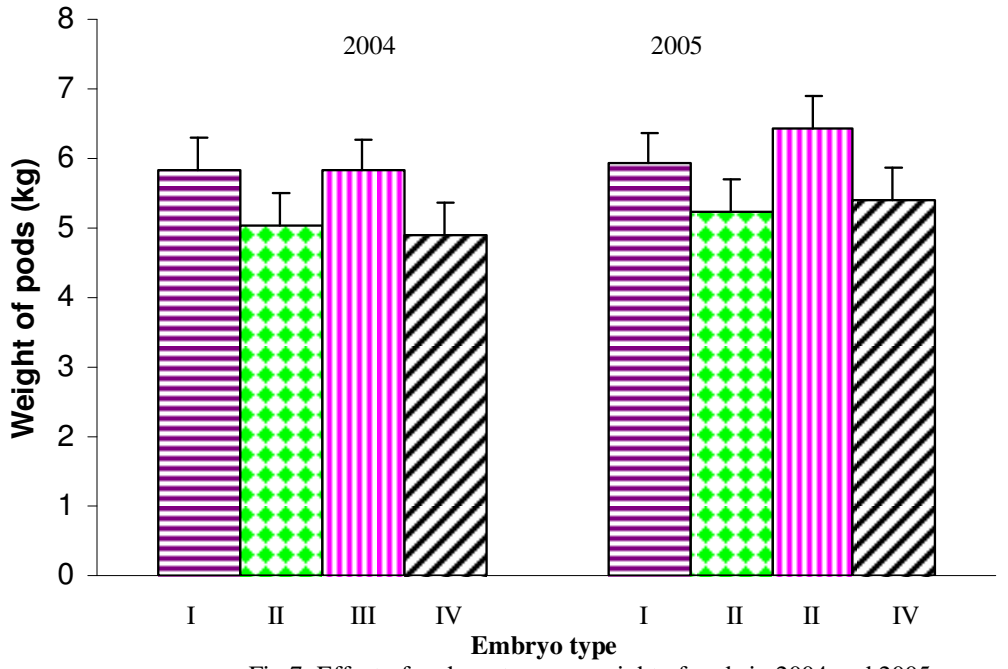

ㅂ I.Single embryo

$\square$ II. Twin embryo

口 III.Triple embryo

口 IV.Quadruple embryo

Fig 7: Effect of embryo type on weight of pods in 2004 and 2005

\section{DISCUSSION}

The expression of the three morphotypes of polyembryony (twin, triple and quadruple) and the single embryo type in 2004 and 2005 implies that these traits are heritable and occur at different frequencies. The consistent high and low frequencies of occurrence of the triple and the quadruple embryo types suggests that in any fluted pumpkin pod, there are likely to be more seeds that will exhibit tri-embryony than any other embryo type, while only a few seeds will have more than the triple embryos.
There was no clear trend across all the embryo types with respect to all the characters measured in 2004 and 2005. The inconsistency in the performance of the different embryo types might be due to the dioecious nature of the crop. This finding agrees with Pemberton (2001), who reported that varietal purity will be difficult to maintain in the crop because it is a cross pollinated crop.

The production of lower number of leaves by the twin embryo type than the other embryo types at 4WAP in 2004, could be as a result of a positive synergistic effect among the 
embryos of the triple and quadruple embryo types with respect to number of leaves at that age. This implies that genetic heterogeneity of the seeds that resulted in triple and quadruple embryo types have initial cells of sexual embryos that positively encouraged production of leaves. According to Batygina and Vinogradova (2007), genetic heterogeneity is one of the most important characteristics of seeds, which is based on different phenomena, such as embryologeny, embryoidogeny, and gametophytic and sporophytic apomixes. However, in 2005, the number of leaves produced by the twin embryo type was comparable to the number of leaves produced by the single embryo type. The concomitant reduction in the number of leaves with increase in the number of embryos at 8WAP in 2004 could be as a result of competition for nutrients, especially among the polyembryonic plants that developed side shoots which grew together with the main shoot.

The inconsistency in the performance of the embryo type with respect to the number of leaves at both 4 and 8 WAP in 2004 and 2005 implies that the expression of the genetic potentials of the different embryo types as regards leaf production must be carefully maintained through vegetative propagation (vine cuttings) or tissue culture techniques. Propagation of such fluted pumpkin lines through tissue culture could find applications in clonal propagation for achieving mass and cheap multiplication using the methods proposed by Levin et al (1988) and Okonkwo (1997); phytosanitation through meristem culture (Kassanis, 1957; Ng, 1991); micropropagation through callus and embryogenesis (Sharp et al., 1982) and protoplast culture (Pierik, 1987). This is in agreement with the report of Esiaba (1982) that polyembryonic trait in $T$. occidentalis would serve a good and economical means of clonal multiplication following successful selection of desired trait.

The impressive performance of quadruple embryo type with respect to length of vine at 8 WAP in 2004 and 2005 could be due to the degeneration of the weaker side shoots and the subsequent mobilization of the available assimilates for the support of the surviving shoot. According to Bidinger et al. (1996), variety reponse rate is controlled by the genetic potential of a variety. The authors reported that the stability of yield production depends on the ability of a variety to respond to environmental conditions.

The number of branches increased significantly with increase in the number of shoots of some of the embryo types in 2004 and 2005. The result at 4WAP for quadruple and to a large extent, triple is consistent with that of 8WAP, with respect to number of branches. Therefore, it is reasonable to assume that adoption of a proper cutting management practice on the polyembryonic lines will result in a better performance with respect to other characters such as number of leaves, vine length and weight of pods. Asiegbu (1985) reported that higher leaf yields with frequent harvest schedules was mostly due to greater branching resulting from more frequent removal of apical dominance with cutting of the terminal buds, which allowed for more flushes and for better and regular timing for taking advantage of new flushes following harvest. Mica (1986) also reported proliferation of branches with frequent defoliation of other vegetable crops. Bagust (1992) reported that pruning improves the quantity and quality of vegetable crops. The author also noted that increase in vegetative growth and fruit formation will be encouraged if vegetable crops are pruned. He suggested that pruning will assist in the removal of dead parts, thereby encouraging aeration and greater access to light.

The impressive performance of the single and triple embryo types over the twin and quadruple embryo types as regards to the weight of pods, in 2004 and 2005 suggests that these embryo types are good candidates for vegetative and micropropagation techniques for pod production in $T$. occidentalis. This finding is in contrast to the report of Sedgely and Griffing (1989) on Irvingia gabonensis (Bush mango). The authors reported that the assessment of six kernels from a polyembryonic fruit was about equivalent to the weight of the single kernel of normal fruits from the same accession. They concluded that from a production point of view, it will be unnecessary to select for the polyembryonic trait.

In general, with respect to agronomic value of polyembryony in fluted pumpkin, it could be concluded that the inconsistency in the performance of the different embryo types might be due to the dioecious nature of the crop. However, the triple and single lines were more impressive when compared with the twin and quadruple lines, especially with respect to weight of pods. Thus, the triple and single lines are promising and can be advanced further as possible candidates for clonal multiplication for desired traits like optimum leaf and pod production.

It is hoped that the application of tissue culture technique or successful vegetative propagation technique in large scale production 
of the promising embryo types will result in a remarkable increase in the supply of nutrient rich fluted pumpkin leaves and pods. To a large extent, this will help to overcome the difficulty in maintaining varietal purity due to the dioecious nature of fluted pumpkin.

\section{REFERENCES}

Akobundu, I.O. (1987). Weed Science in the Tropics. John Widely and Sons Ltd. $522 \mathrm{pp}$.

Akoroda, M.O. (1990). Seed production and breeding potential of fluted pumpkin (Telfairia occidentalis). Euphytica 49: 25-32.

Akubue, P. I., Kar, A. and Nnachetta, F.N. (1980) Toxicity of extracts of roots and leaves of Telfairia occidentalis. Planta Medica. 38: 339-343

Asiegbu, J.E. (1985). Characterization of Sexes in Fluted Pumpkin: Growth aand Yield in the Male and Female Sexes. Horticultural Science 50 (6): 251- 255.

Asiegbu, J.E. (1987). Some biochemical evaluation of fluted pumpkin seeds. $J$. Sci Food Agric. 40: 152-155.

Bagust, H. (1992). The ardener's Dictionary of Horticultural Terms. 245pp.

Batygina, T. and Vinogradova, G. (2007). Phenomenon of Polyembryony. Genetic heterogeneity of seed. Russian Journal of Developmental Biology. 38 (3) 126 -151.

Bidinger, F. R., Hammer, G. L. and Muchow, R. C. (1996). The physiological basis of genotype by environment interaction in crop adaptation. In: Plant Adaptation and Crop Improvement. CAB International. pp 329-348.

Esiaba, R.O. (1982). Cultivating the fluted pumpkin in Nigeria. World Crops, March/April. 70-72.

Guo, W. W., Chang, Y. J., Chen, L. C. and Deng, X. X. (2006). Molecular analysis revealed autotetraploid, diploid and tetraploid hybrid plants regenerated from an interspecific somatic fusion in Citrus. Scientia Horticulturae 108:162-166.

Irvine, F.R. (1969). West African Crops, Oxford University Press. 272pp.

Kassanis, B. (1957). The use of tissue culture to produce virus-free clones from infected potato varieties. Ann. Appl. Biol. 45: 447-450.
Levin, L., Gaba, V., Tai, B., Hirsh, S., DeNola, D. and Vasil, I. K. (1988). Automated plant tissue culture for mass propagation. Bio/Technology 6:1035-1040.

Mica, A. (1986): Physiological responses of fruit trees to pruning. Horticultural Rev. 8: 337-378.

Obi, I.U. (1986). Statistical methods of detecting differences between treatment means. Department of Crop Sc., UNN, Nigeria, pp 1-45

.Odiyi, A.C. (2003). Developmental patterns of the multiple seedling trait in Telfairia occidentalis Hook.f. J. Sustain Agric. Environ. 5(2): 319-325.

Okonkwo, S. Y. C. (1997). Modern crop manipulations for increased productivity. Paper presented at the International Conference on "Biotechnology for Development in Africa: Priorities for the early $21^{\text {st }}$ century" organized by FADIB, Enugu, Nigeria.

Ng, S. Y. C. (1991). In vitro conservation and distribution of root and tuber crop germpasm. Proc. Int. Conf. on Crop Genetic Resources of Africa, 17-20 October, Ibadan, Nigeria. pp. 95-106.

Odiaka, N. I.; Akoroda, M. O. and Odiaka, E. C. (2008). Diversity and production methods of fluted pumpkin (Telfairia occidentalis Hook. f.); Experience with vegetable farmers in Markurdi, Nigeria. African Journal of Biotecnology 7 (8): 944-954.

Pierik, R. L. M. (1987). In vitro Culture of Higher Plants. Martinus Nijhoff Publisher's Group, Dordrecht, 344pp.

Pemberton, R.W. (2001). Finding and Fruiting the Fluted Pumpkin. The Cucurbit Network. 8(1): 1-3.

Purseglove, J.W. (1984). Tropical Crops. Dicotyledons. Volumes 1 and 2. English Language Book Society and Longmans, London. p 100.

Sedgely, M. and A. R. Griffing (1989). Sexual reproduction of tree crops Academic press, Sydney, Australia 378pp.

Sharp, W. R., Evans, D. A. and Sondahl, M. R. (1982). Applications of somatic embryogenesis to crop improvement. Proc. $5^{\text {th }}$ Int. Cong. Plant Tissue Culture, Tokyo, Japan (A. Fujiwara, ed.) pp. 759-762.

Steel, G. D. and J. H. Torrie (1980). Principles and Procedures of Statistics: A Biometrical Approach. $3^{\text {rd }}$ edition. Hill Book Company Inc.New York. 633pp. 